\title{
Human Health and Ecological Risk Assessment for the Operation of the Explosives Waste Treatment Facility at Site 300 of the Lawrence Livermore National Laboratory
}

\section{Volume 1: Report of Results}

Gretchen Gallegos

Jeffrey I. Daniels

Anthony Wegrecki

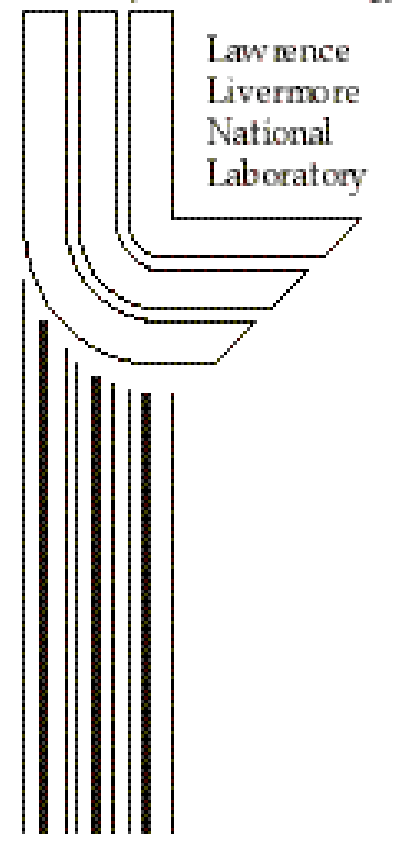

November 2005 
This work was performed under the auspices of the U. S. Department of Energy by the University of California, Lawrence Livermore National Laboratory under Contract No. W-7405-Eng-48. 


\section{Human Health and Ecological Risk Assessment for the Operation of the}

Explosives Waste Treatment Facility at Site $\mathbf{3 0 0}$

of the Lawrence Livermore National Laboratory

Table of Contents

BACKGROUND INFORMATION ABOUT TYPES OF EXPLOSIVES .......................................... iii

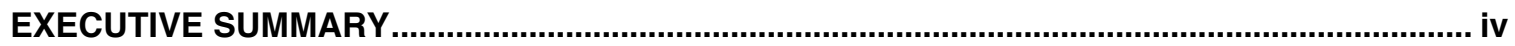

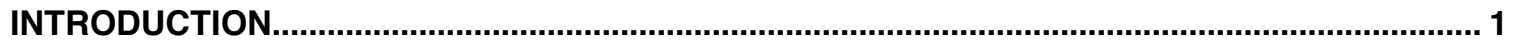

OB/OD OPERATIONS AT SITE 300

APPROACH

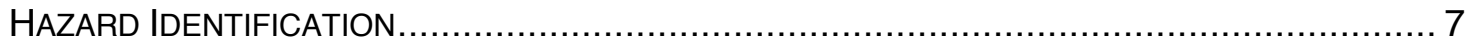

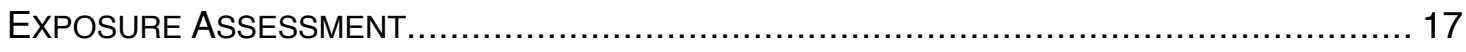

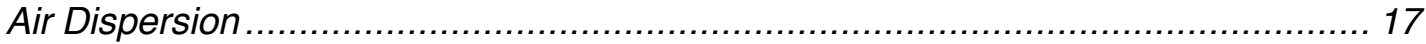

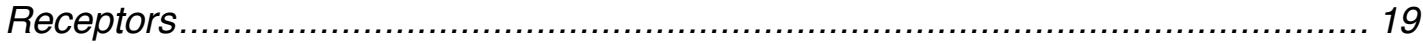

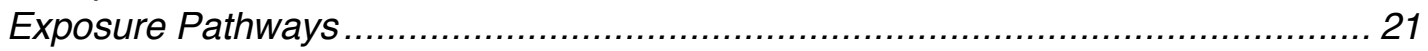

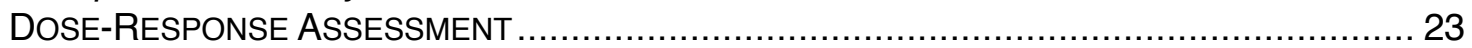

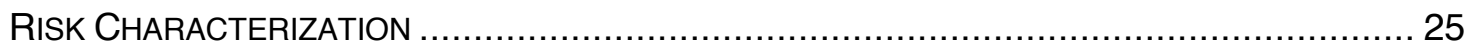

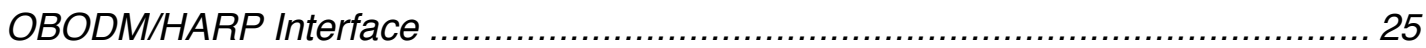

Identification of Maximally Exposed Receptors............................................. 26

Effects on Maximally Exposed Receptors................................................ 26

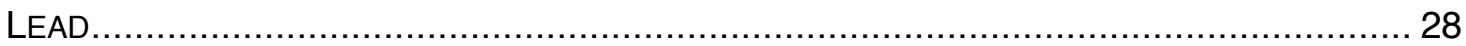

ECOLOGICAL RISK ASSESSMENT

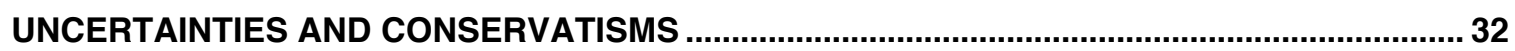

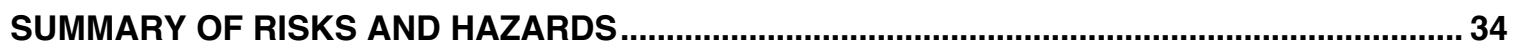

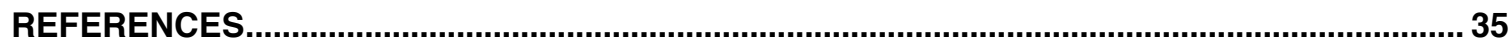

\section{Appendices}

Appendix A. Integration of OBODM into HARP

Appendix B. Ecological Risk Assessment In Support of Renewal

of the Permit for the Explosive Waste Treatment

Facility (EWTF) at Site 300 of the Lawrence

Livermore National Laboratory

\section{Figures}

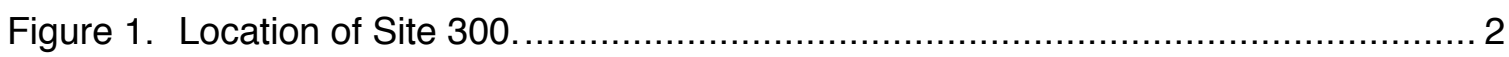

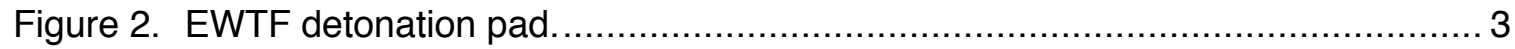

Figure 3. EWTF burn pan, covered. (UCRL-Photo-213179, July 16, 2005) .................. 4

Figure 4. EWTF burn cage. (UCRL-Photo-213179, July 16, 2005) .............................. 5 
Figure 5. EWTF control bunker (Building 845A). Detonation pad is in the background..... 5

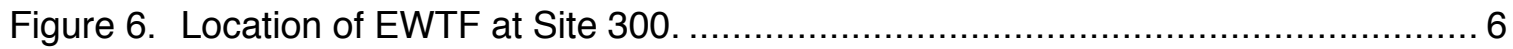

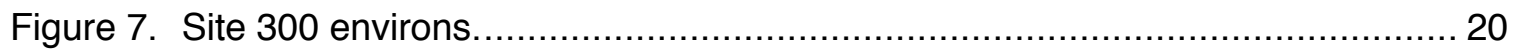

Figure 8. Locations of potentially maximally exposed receptors. ................................ 21

\section{Tables}

Table 1. Mass amounts of treated material by treatment unit and waste form. ............ 8

Table 2. Materials tested in the BangBox experiments, the treatment

frequency at the EWTF, type of treatment at EWTF, and

associated EWTF waste form

Table 3. Emissions factors for the burn pan, burn cage, and detonation pad

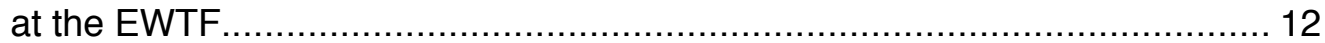

Table 4. Calculation of the emission factor for cadmium for detonation pad............... 13

Table 5. Maximum hourly estimated emissions for the burn pan, burn cage (Forms 3 and 4), and detonation pad at the EWTF.

Table 6. Maximum annual estimated emissions for the burn pan, burn cage (Forms 3 and 4), and detonation pad) at the EWTF.

Table 7. Exposure parameters used in EWTF risk assessment. Unless otherwise noted, all parameters are implemented in HARP (CARB, 2003) as described in OEHHA (2003) and represent high endpoints. 22

Table 8. Food consumption fraction estimated to be affected by EWTF

Table 9. Cancer potency factors, relative exposure levels, and reference doses for chemicals of concern for the EWTF.

Table 10. Screening results for identifications of maximally exposed receptors.............26

Table 11. Health effects for maximally exposed receptors. .................................... 27

Table 12. Values for input factors required for the lead risk assessment spreadsheet model, LeadSpread 7.

Table 13. Predicted blood-lead levels for adult and child exposures at the Ranger Location and for adult-worker exposures at the Building 895 location using the lead risk assessment spreadsheet model, LeadSpread 7.

Table 14. Ecological hazard quotients (i.e., ratio of total dose to respective body-weight-scaled TRV) for each representative receptor of interest and contaminant of potential ecological concern. 


\title{
Background Information about Types of Explosives
}

\author{
(adapted from Mitchell, 1999)
}

High Explosive. An energetic material in which the decomposition process (detonation wave) proceeds through the entire material at supersonic speed. The rate at which the detonation wave passes through the energetic material depends on a large number of parameters, including the density of the energetic material, the heat released by the detonation, the geometric shape or dimensions of the energetic material, the degree of confinement, and the purity of the energetic material(s). High explosives can be divided into two subcategories: primary high explosives that detonate easily when exposed to an ignition source, and secondary high explosives that require the detonation of a primary high explosive before they detonate. Fuses and boosting charges are examples of primary high explosives; trinitrotoluene (TNT), Research Department Explosive (RDX), tetryl, and nitroglycerin are examples of secondary explosives.

Low Explosive. An energetic material in with the decomposition process (deflagration) occurs at subsonic speed. The decomposition occurs only on the surface of the energetic material, and, unlike the high explosive, there is no shock wave. The rate determining factors for decomposition of a low explosive are the rate of heat transfer into the energetic material from the decomposition occurring on its surface; and the rate of decomposition of the energetic material itself. The pressure the decomposition products exert on the energetic material also affects the rate of heat transfer. Low explosives are usually divided into three largely unrelated categories: black powder (a mixture of sulfur, charcoal and potassium nitrate), pyrotechnics (materials used to produce light, smoke, heat or sound effects), and propellants (materials used for the propulsion of projectiles or rockets).

Propellant. A low explosive energetic material. Some of the most commonly used propellant ingredients are nitrocellulose, nitroglycerin, and ammonium perchlorate. Propellants are placed into five subcategories based on their energetic composition: (1) single base, which contains only nitrocellulose, (2) double-base, which contains nitrocellulose and nitroglycerin, (3) triple-base, which contains nitrocellulose, nitroglycerin, and nitroguanidine, (4) ammonium perchlorate, and (5) composite, which contains an oxidizer such as ammonium perchlorate and a metal additive (e.g., powdered aluminum) held together by a polymeric substance such as polybutadiene. 


\section{Human Health and Ecological Risk Assessment for the Operation of the Explosives Waste Treatment Facility at Site $\mathbf{3 0 0}$ of the Lawrence Livermore National Laboratory}

\section{Executive Summary}

Human health and ecological risk assessments are required as part of the Resource Recovery and Conservation Act (RCRA) permit renewal process for waste treatment units. This risk assessment is prepared in support of the RCRA permit renewal for the Explosives Waste Treatment Facility at Site 300 of the Lawrence Livermore National Laboratory. The human health risk assessment is based on U.S. Environmental Protection Agency approved emissions factors and on California Environmental Protection Agency, Air Resources Board and U.S. Environmental Protection Agency risk assessment and air dispersion models. The risk assessment identifies receptors of concern and evaluates carcinogenic risk, and acute and chronic noncarcinogenic hazard. The carcinogenic risk to a 30-year resident at the maximum offsite receptor location is 0.0000006 or 0.6 in one million. The carcinogenic risk to a 25 -year worker at the maximum bystander on-site receptor location is also 0.0000006 or 0.6 in one million. Any risk of less than 1 in a million is below the level of regulatory concern. The acute noncarcinogenic hazard for the 30-year resident is 0.02 and the chronic noncarcinogenic hazard is 0.01 . The acute noncarcinogenic hazard for the 25-year worker is 0.3 and the chronic noncarcinogenic hazard is 0.2 . The point of comparison for acute and chronic noncarcinogenic hazard is 1.0, an estimate less than 1.0 is below the level of regulatory concern. The estimates of health effects are based on health conservative assumptions and represent an upper bound of the possible exposures to the receptors. For the ecological risk assessment, four receptor species were evaluated for potential detrimental effects; none were found to be adversely affected because for each species the predicted ecological hazard quotients are always less than one. Based on these results, emissions from the operations of the Explosive Waste Treatment Facility should not be considered to be of concern for human health or ecological reasons. 


\section{Human Health and Ecological Risk Assessment for the Operation of the Explosives Waste Treatment Facility at Site $\mathbf{3 0 0}$ of the Lawrence Livermore National Laboratory}

\section{Introduction}

This document contains the human health and ecological risk assessment for the Resource Recovery and Conservation Act (RCRA) permit renewal for the Explosives Waste Treatment Facility (EWTF). Volume 1 is the text of the risk assessment, and Volume 2 is the supporting modeling data. The EWTF is operated by the Lawrence Livermore National Laboratory at Site 300, located in the foothills between the cities of Livermore and Tracy, approximately 17 miles east of Livermore and 8 miles southwest of Tracy. Figure 1 is a map of the San Francisco Bay Area, showing the location of Site 300 and other points of reference.

One of the principal functions at Site 300 is to test what are known as "high explosives" for nuclear weapons. These are the highly energetic materials that provide the force to drive fissionable material to criticality. LLNL scientists develop and test the explosives and the integrated non-nuclear components in support of the nuclear stockpile stewardship program as well as in support of conventional weapons and the aircraft, mining, oil exploration, and construction industries.

Many of the Site 300 facilities are used in support of high explosives research. Some facilities are used in the chemical formulation of explosives; others are locations where explosive charges are mechanically pressed; still others are locations where the materials are inspected radiographically for defects such as cracks and voids. Finally, some facilities are locations where the machined charges are assembled before they are sent to the on-site test firing facilities.

Wastes generated from high-explosives research are treated by open burning $(\mathrm{OB})$ and open detonation (OD). $\mathrm{OB}$ and $\mathrm{OD}$ treatments are necessary because they are the safest methods for treating explosives wastes generated at these facilities, and they eliminate the requirement for further handling that would be required if the wastes were treated off site. 


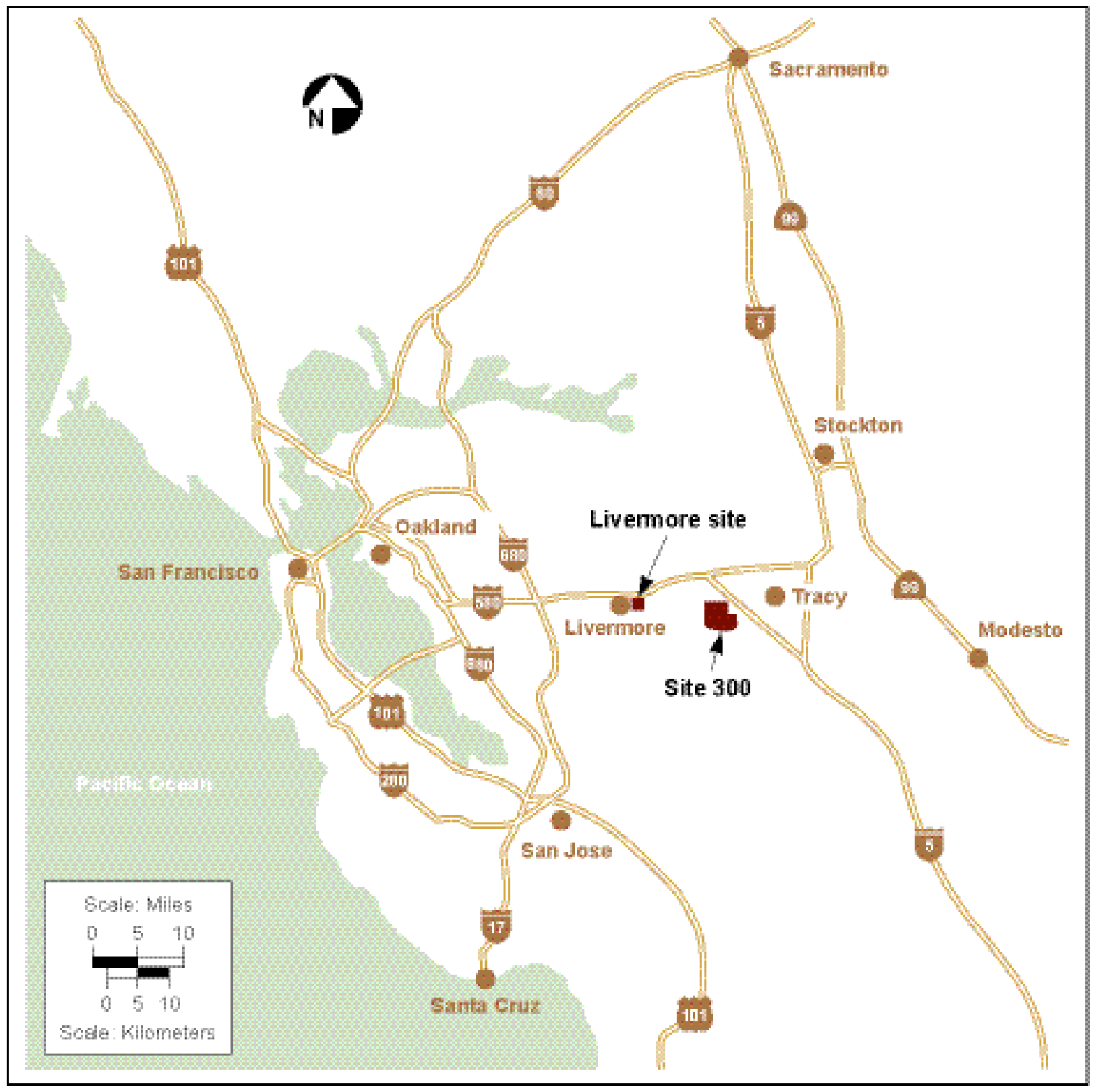

Figure 1. Location of Site 300. 


\section{OB/OD Operations at Site 300}

OB / OD operations are conducted at the Explosives Waste Treatment Facility (EWTF) located at the Building 845 Complex at Site 300. The EWTF consists of three units: the detonation pad, the burn pan, and the burn cage.

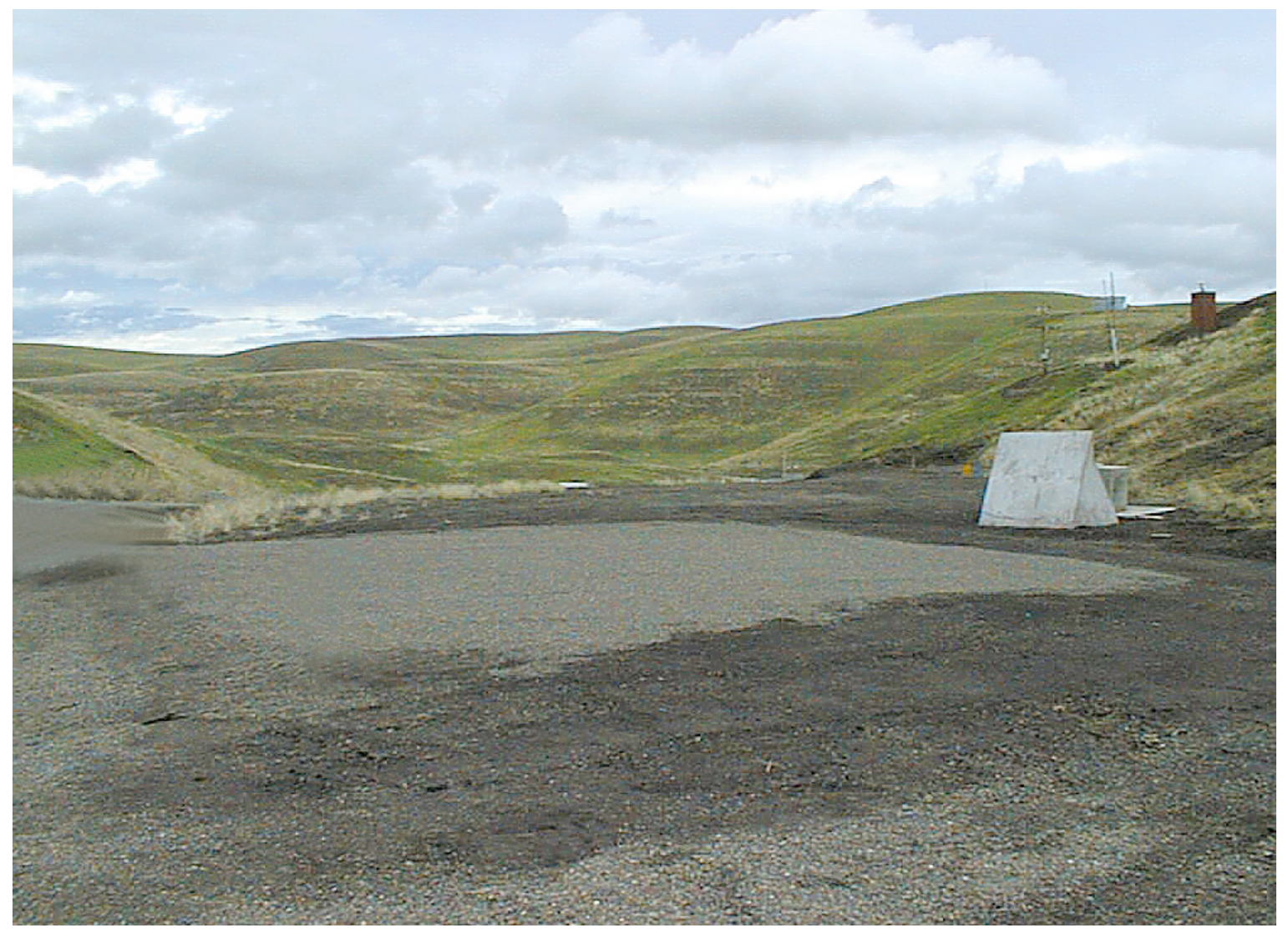

Figure 2. EWTF detonation pad.

The detonation pad, shown in Figure 2, is used for the treatment of those waste explosives whose configuration requires treatment by open detonation, i.e., the wastes are in a form that cannot be safely treated by open burning. The materials treated are 90 to $100 \%$ explosive materials. The detonation pad consists of a level, 30 -foot $\times 30$-foot $(9-\mathrm{m} \times 9$-m) gravel pad with a minimum gravel pack about 8feet $(2.4-\mathrm{m})$ thick. Detonation of explosives waste is accomplished with the use of detonators or other initiating devices, and the process is controlled remotely from the Building 845 control bunker under observation by surveillance cameras. No more than 350 pounds ( $159 \mathrm{~kg}$ ) of explosives waste (net explosive weight) may be detonated at one time. The detonation process is virtually instantaneous.

The burn pan is used for the treatment of small pieces and powders of explosives wastes; these materials are 80 to $100 \%$ explosive materials that will not detonate during the thermal treatment process. The burn pan is a 4 -foot $x 8$-foot $x 0.5$-footdeep rectangular, welded steel, watertight pan mounted on steel legs. The pan is 
equipped with a remotely controlled, removable cover. Pieces of explosives waste are placed in the pan, and cellulose material or other combustible materials are used to initiate treatment by burning. No more than 100 pounds (45 kg) of explosives waste (net explosive weight) may be treated at one time. The duration of the combustion treatment is 10 minutes or less. Figure 3 is a photograph of the burn pan.

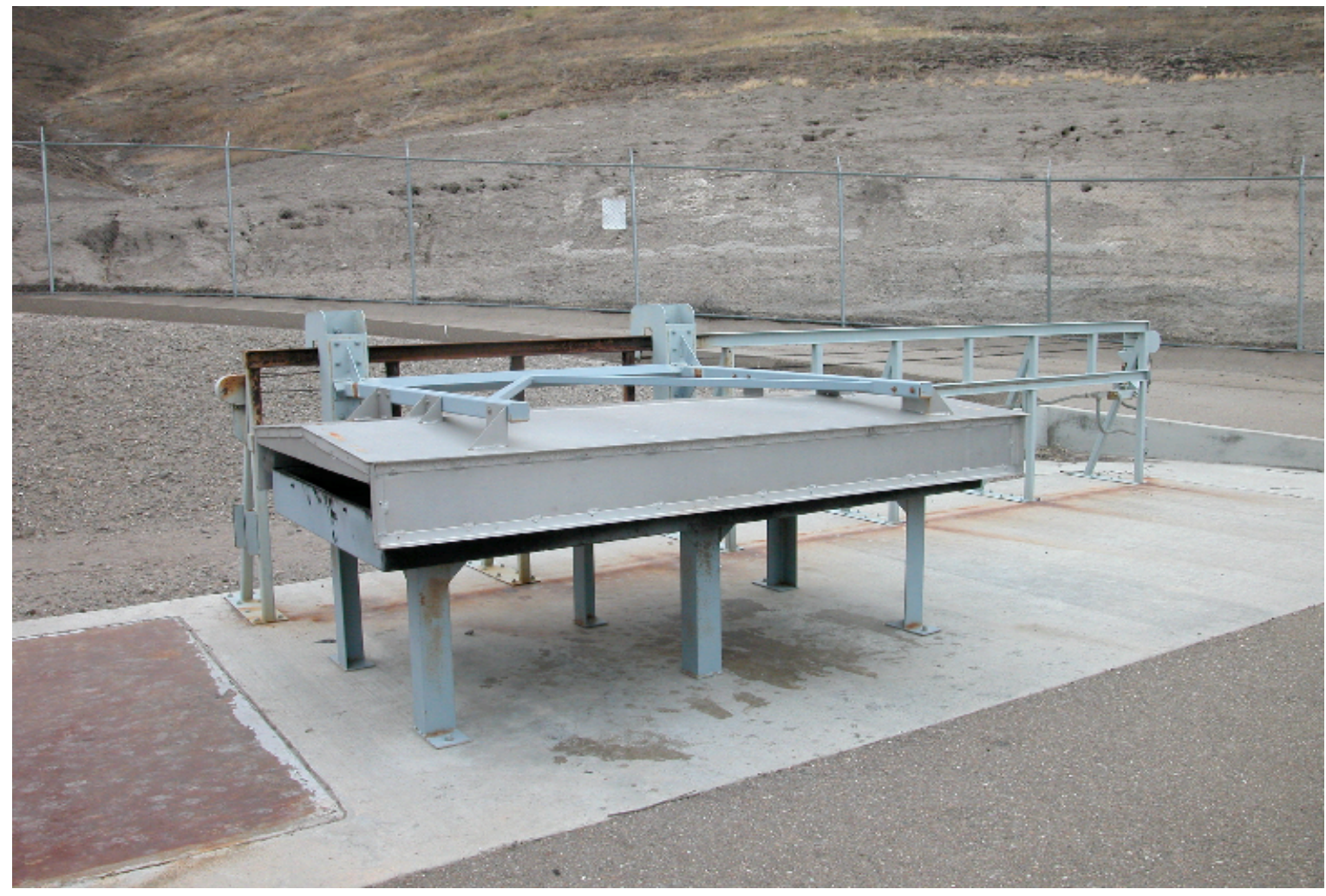

Figure 3. EWTF burn pan, covered. (UCRL-Photo-213179, July 16, 2005)

The burn cage is used for the treatment of explosives-containing process waste sludge, explosives-contaminated packaging, and explosives contaminated laboratory waste. The explosive content of the material treated in the burn cage ranges from 1 to $80 \%$. The burn cage is an 8 -foot diameter, ventilated, metal enclosure with a refractory lining and an elevated metal base. Propane fuel from a protected supply tank is supplied to the burn cage to assist the combustion process. No more than 260 pounds $(118 \mathrm{~kg})$ of total waste and 50 pounds $(23 \mathrm{~kg})$ net explosive waste may be treated in the burn cage at one time. Combustion treatments at the burn cage are completed in 35 minutes. Figure 4 is a photograph of the burn cage.

EWTF operations and controls are handled from a concrete and steel bunker (Building 845; see Figure 5). 


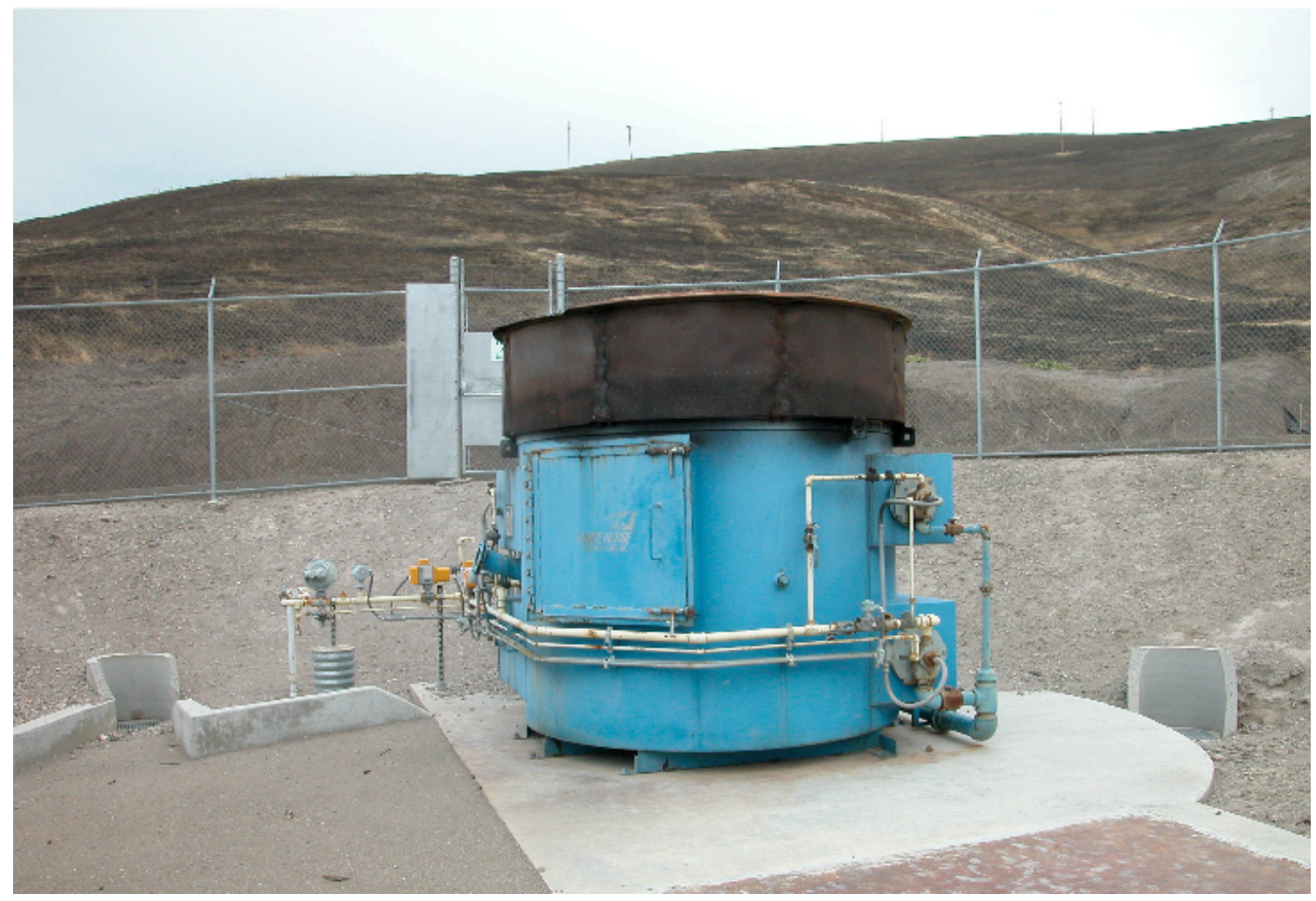

Figure 4. EWTF burn cage. (UCRL-Photo-213179, July 16, 2005)

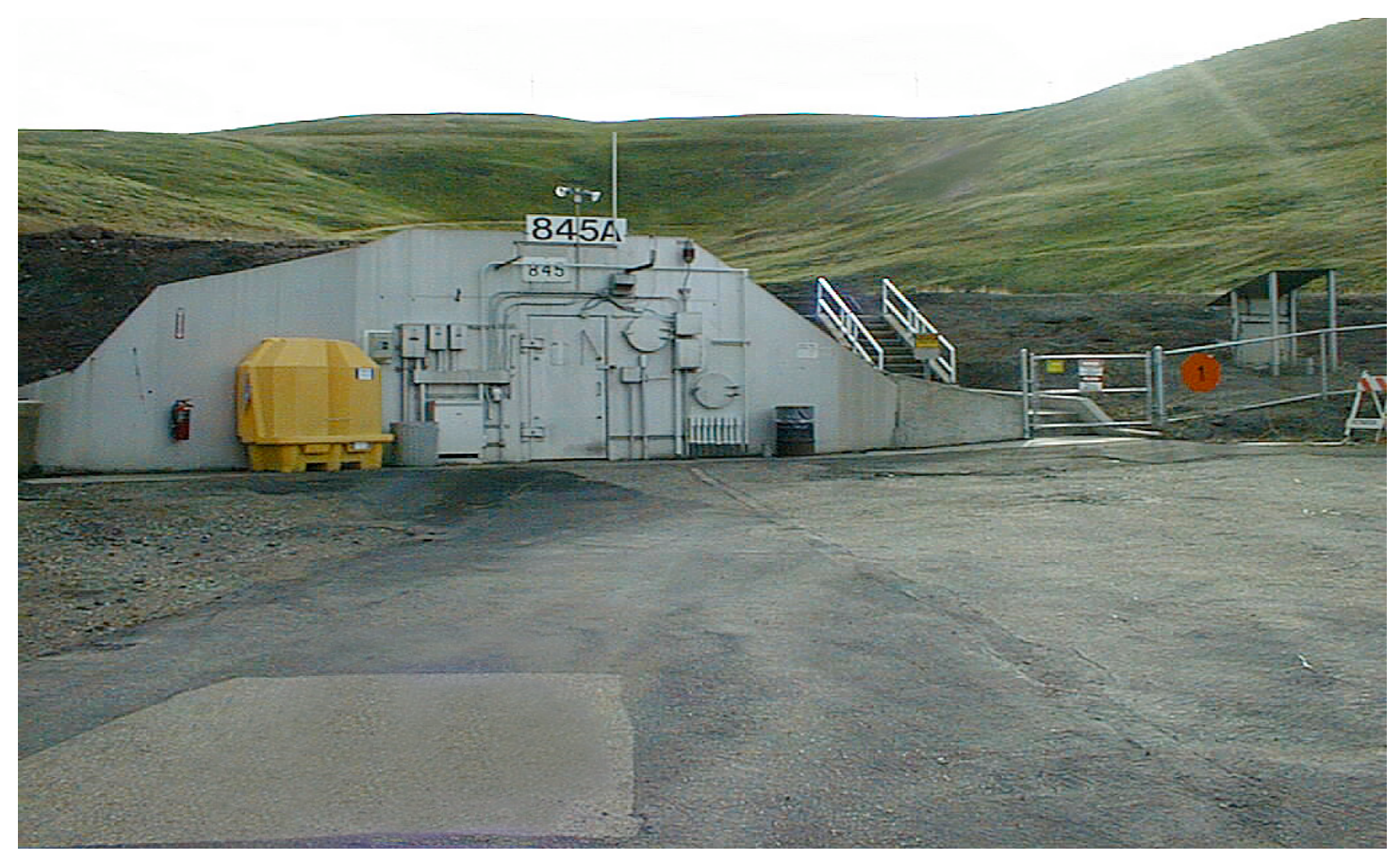

Figure 5. EWTF control bunker (Building 845A). Detonation pad is in the background. 
Figure 6 is a site map for Site 300, showing the central location of the EWTF, which maximizes the distance to off-site receptors; the inset in Figure 6 shows the relative locations of the detonation pad, the burn pan, and the burn cage.

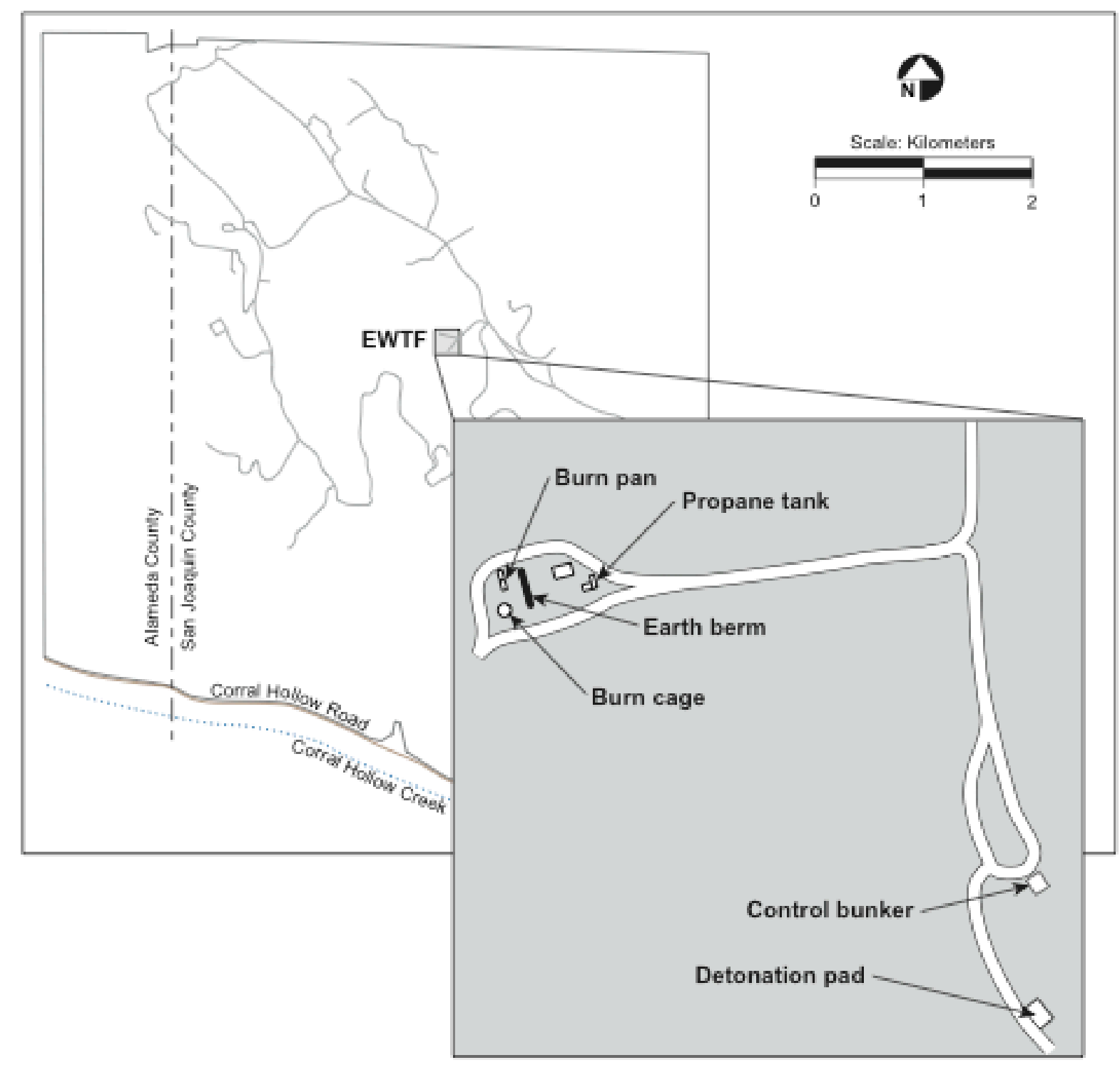

Figure 6. Location of EWTF at Site 300. 


\section{Approach}

The standard approach for human health risk assessment is a four-step process stated by the National Academy of Sciences in Risk Assessment in the Federal Government: Managing the Process (NAS, 1983) and reiterated in The Air Toxics Hot Spots Program Guidance Manual for Preparation of Health Risk Assessments (OEHHA, 2003). The four steps in the process are (1) hazard identification, (2) exposure assessment, (3) dose-response assessment, and (4) risk characterization.

For the operations at EWTF, hazard identification, the first step, involves identifying emissions from the operations, i.e., the source term of specific pollutants of concern. Exposure assessment, the second step, involves emission quantification, modeling of environmental transport and fate, identification of exposure routes, identification of maximally exposed individuals, and estimation of short and long-term exposures. The third step, dose-response assessment, characterizes the relationship between the exposure to a pollutant and any potential resulting health effect. For quantitative carcinogenic risk assessment, the dose-response relationship is estimated using cancer potency factors compiled by OEHHA and the U.S. EPA to calculate the risk of cancer associated with the estimated exposure. For noncarcinogenic acute and chronic effects, the dose-response relationship is quantified by comparison of modeled air concentrations with OEHHA- and U.S. EPA-defined acute and chronic reference exposure levels (RELs) for the inhalation pathway, and for the ingestion pathway, modeled dose is compared with a reference dose (RfD). The fourth and final step, risk characterization, combines the modeled exposures of the specific pollutants of concern with the dose-response relationship defined by regulatory authority to estimate the potential health risks associated with the exposures. Each of these steps is discussed in this risk assessment.

\section{Hazard Identification}

The EWTF is a support facility at LLNL's Site 300 where wastes resulting from research activities involving explosives are treated. Most of the explosive wastes treated at Site 300 involve high explosives, such as the compounds RDX, high melting explosive (HMX), and pentaerythritol tetranitrate (PETN), in a variety of formulations. Explosives other than high explosives are treated more rarely. The wastes treated at the EWTF are categorized into four forms, which are described below.

Form 1 Waste. Waste explosives that because of configuration or composition are best treated by open detonation. Examples are explosive assemblies or devices that may detonate during open burning.

Form 2 Waste. Waste explosives that because of configuration or composition are best treated by open burning in the open burn pan. Examples are explosive parts and pieces generated during explosives formulation, processing, testing, or by removal from inventory. 
Form 3 Waste. Waste explosives that because of configuration or composition are best treated by open burning in the thermal treatment unit (burn cage). Examples are wet machine fines generated during explosives processing, wet explosives-contaminated sludge from weirs and settling basins, and wet expendable filters from recycle systems.

Form 4 Waste. Waste material contaminated with energetic materials that are best treated by open burning in the thermal treatment unit (burn cage). Examples are paper, rags, plastic tubing, dry expendable filters from vacuum systems, and personal protective equipment used in explosives operations. The waste is judged to retain explosives hazards and is therefore considered to be a reactive waste.

Current permit limits allow 100 open detonations (Form 1 waste) and 100 open burn treatments (Forms 2, 3, or 4) annually. Table 1 presents the maximum mass amounts of treated material by treatment unit and waste form.

Table 1. Mass amounts of treated material by treatment unit and waste form.

\begin{tabular}{|l|c|c|c|}
\hline Treatment unit/Waste form & $\begin{array}{c}\text { Annual } \\
\text { number of } \\
\text { treatments }\end{array}$ & $\begin{array}{c}\text { Maximum } \\
\text { single } \\
\text { treatment (Ib) }\end{array}$ & $\begin{array}{c}\text { Annual } \\
\text { treatment (Ib) }\end{array}$ \\
\hline Detonation Pad/Form 1 & 100 & 350 & 35,000 \\
Burn Pan/Form 2 & 100 & 100 & $10,000^{*}$ \\
Burn Cage/Form 3 & 50 & $5,000^{*}$ \\
Burn Cage/Form 4 & & 260 & $26,000^{*}$ \\
\hline
\end{tabular}

* Assuming 100 treatments at each unit; no accounting is made for the allocation of 100 permitted burn treatments among the three burn treatment options.

The estimation of potential emissions for explosives wastes is a subject of interest to both the U.S. Environmental Protection Agency (EPA) and the U.S.

Department of Defense (DoD). The DoD has been seriously studying emissions from OB/OD operations since 1984. In the first comprehensive test, helicopters equipped with air sampling equipment were flown through plumes from $\mathrm{OB}$ and OD tests. The results were inconclusive. In 1988, the DoD began a series of studies that were contained in a large chamber called a BangBox at Sandia National Laboratories, Albuquerque, NM. After the first two studies, "the U.S. Army concluded that the emission factors derived from the BangBox tests were: (1) more reliable and reproducible than those from the field tests; (2) were [sic] statistically equivalent to these determined from the field tests; and (3) supported the original assumption that the detonations and burns were producing emission products consistent with detonation theory." (Mitchell and Suggs, 1998, p. 9) The Army also determined that the materials emitted from field tests and BangBox studies were similar for all materials tested and were primarily $\mathrm{N}_{2}, \mathrm{CO}_{2}, \mathrm{H}_{2} \mathrm{O}$, particles, metals, and small quantities of $\mathrm{CO}, \mathrm{NO}, \mathrm{NO}_{2}$, low molecular weight volatile organic compounds (VOCs) and semi-volatile organic compounds (SVOCs) often found in ambient air.

In 1992, the EPA agreed to accept emission factors for OB/OD based on BangBox studies. The Army built a BangBox at Dugway Proving Grounds in Dugway, UT, 
and conducted an additional series of studies that encompassed the open burning of 16 energetic materials and open detonation of 23 energetic materials. In 1998, EPA released a report summarizing the results and presenting emissions factors for OB/OD operations (Mitchell and Suggs, 1998). These emissions factors were incorporated into the Open Burn/Open Detonation Dispersion Model (OBODM) developed expressly for modeling OB/OD operations (Bjorklund et al., 1998). The emission factors in OBODM were used to characterize air emissions due to EWTF treatment activities.

Table 2 lists all 39 energetic materials contained in OBODM; it also lists the EWTF waste form in which the materials could be found, the methods by which the materials can be treated at the EWTF, and the frequency that the materials are treated at the EWTF. As seen in Table 2, three materials are routinely treated, fifteen materials are treated with less than 5 percent frequency and six materials are treated with less than 1 percent frequency. Five materials could be treated after additional internal review, but are not expected to be treated. Ten materials are not treated at the EWTF.

A reasonable ${ }^{1}$ yet conservative approach was used to characterize air emissions due to EWTF treatment activities (i.e., emissions from form 1 waste treatment at the detonation pad, form 2 waste treatment at the burn pan, form 3 waste treatment at the burn cage, and form 4 waste treatment at the burn cage). First, a subset of the energetic materials contained in OBODM, with similar compositions to those treated at the EWTF, was identified. Second, the identified materials were mapped to the EWTF waste form in which they could be present. Third, the energetic materials (and their emission factors) were grouped by type of treatment and waste form. For example, the energetic materials (and their emission factors) for form 1 waste treatment at the detonation pad include TNT, RDX, Explosive D, Composition B, Tritanol, Amatol, HBX, etc. (see Table 2). Finally, the maximum chemical-specific emission factor for each type of treatment and waste form was selected (with one exception that will be discussed below).

The resulting emissions factors by type of treatment are presented in Table 3. As previously mentioned, the detonation pad only treats form 1 wastes, the burn pan treats only form 2 wastes and the burn cage treats only form 3 and form 4 wastes.

The emissions factors were used to calculate maximum hourly and annual average emissions from the EWTF. Maximum hourly emissions were calculated

\footnotetext{
${ }^{1}$ This is similar to the approach taken by the U.S. Navy and affirmed by the Agency for Toxic Substances Disease Registry (ATSDR) in evaluating emissions from Isla de Vieques, Puerto Rico, bombing range: (http://www.atsdr.cdc.gov/HAC/PHA/vieques4/vbr p5.html): “ATSDR further believes the Navy contractor's approach used to select emission factors from the available Bangbox studies was appropriate. For instance, to characterize emissions from air-to-ground exercises, the Navy contractor first identified the subset of Bangbox studies that tested explosives with similar compositions to those used at Vieques, and then selected the highest emission factor for every chemical from the various tests. As a result, the emission factors used are the highest measured releases of chemical by-products from the available Bangbox studies."
} 
as follows: The maximum treatment amount for a single treatment was multiplied times the emission factor for each emitted chemical for each waste form. Annual average emissions were calculated in a similar manner: The annual treatment amount was multiplied by the emission factor for each emitted chemical for each waste form.

As stated previously, the emission factor for all chemicals except one was the highest OBODM value for the waste form. The exceptional chemical was cadmium. The maximum cadmium emission factor was 0.0011 for the munition Ground Illumination Signal Red Star M158. This munition is not a waste that would normally be treated at the EWTF; in fact, it would only be treated after an internal review to evaluate its handling. Because it is unlikely that this munition would be treated at all in any one year, its inclusion to represent annual average emissions of cadmium would unreasonably overstate the hazard from the material. ${ }^{2}$ So whereas it is appropriate to use the maximum value to represent a one-hour maximum exposure, in the case in which annual average emissions are estimated, it is more reasonable to use a weighted average of the cadmium emissions factors. The calculation of the weighted average is shown in Table 4.

Table 2. Materials tested in the BangBox experiments, the treatment frequency at the EWTF, type of treatment at EWTF, and associated EWTF waste form.

\begin{tabular}{|c|c|c|c|}
\hline Tested material & $\begin{array}{l}\text { Frequency of } \\
\text { material }^{*} \\
\text { treatment at } \\
\text { EWTF }\end{array}$ & $\begin{array}{l}\text { Type of } \\
\text { treatment at } \\
\text { EWTF }\end{array}$ & $\begin{array}{l}\text { EWTF waste } \\
\text { form }\end{array}$ \\
\hline TNT (2,4,6-Trinitrotoluene) & Routinely treated & $\begin{array}{l}\text { Detonation } \\
\text { Pad (form 1), } \\
\text { Burn Pan } \\
\text { (form 2) } \\
\text { Detonation } \\
\text { Pad (form 1), } \\
\text { Burn Pan }\end{array}$ & 1 and 2 \\
\hline RDX (cyclotrimethylenetrinitramine) & Routinely treated & (form 2) & \\
\hline $\begin{array}{l}\text { Manufacturer's Waste (65\% propell.) } \\
\text { Triple Base (M30-28\% Nitrocellulose }\end{array}$ & $\begin{array}{l}\text { Routınely treated } \\
<5 \%\end{array}$ & $\begin{array}{l}\text { Burn Cage } \\
\text { Burn Pan }\end{array}$ & $\begin{array}{l}3 \text { and } 4 \\
2\end{array}$ \\
\hline M1 (85\% Nitrocellulose) & $<5 \%$ & Burn Pan & 2 \\
\hline Double Base (50\% nitrocellulose) & $<5 \%$ & Burn Pan & 2 \\
\hline Propellant, ammonium perc., alum. & $<5 \%$ & Burn Pan & 2 \\
\hline Propellant, ammonium perc., nonal. & $<5 \%$ & Burn Pan & 2 \\
\hline Propellant, M-43 & $<5 \%$ & Burn Pan & 2 \\
\hline Propellant, M-9 & $<5 \%$ & Burn Pan & 2 \\
\hline Propellant, MK-23 & $<5 \%$ & Burn Pan & 2 \\
\hline Propellant, M31A1E1 & $<5 \%$ & Burn Pan & 2 \\
\hline Propellant, PBXN-110 & $<5 \%$ & Burn Pan & 2 \\
\hline Smokeless Powder & $<5 \%$ & Burn Pan & 2 \\
\hline Propellant, Composite (MK-6) & $<5 \%$ & Burn Pan & 2 \\
\hline Propellant, M-3 & $<5 \%$ & Burn Pan & 2 \\
\hline
\end{tabular}

\footnotetext{
${ }^{2}$ A draft emission factor document, recently placed on the EPA website states that the emission factor for cadmium for this flare is greater than two orders of magnitude lower, i.e., 0.0000022. http:// www.epa.gov/ttn/chief/ap42/ch15/draft/d15s07.pdf Table 15.8.2-2
} 


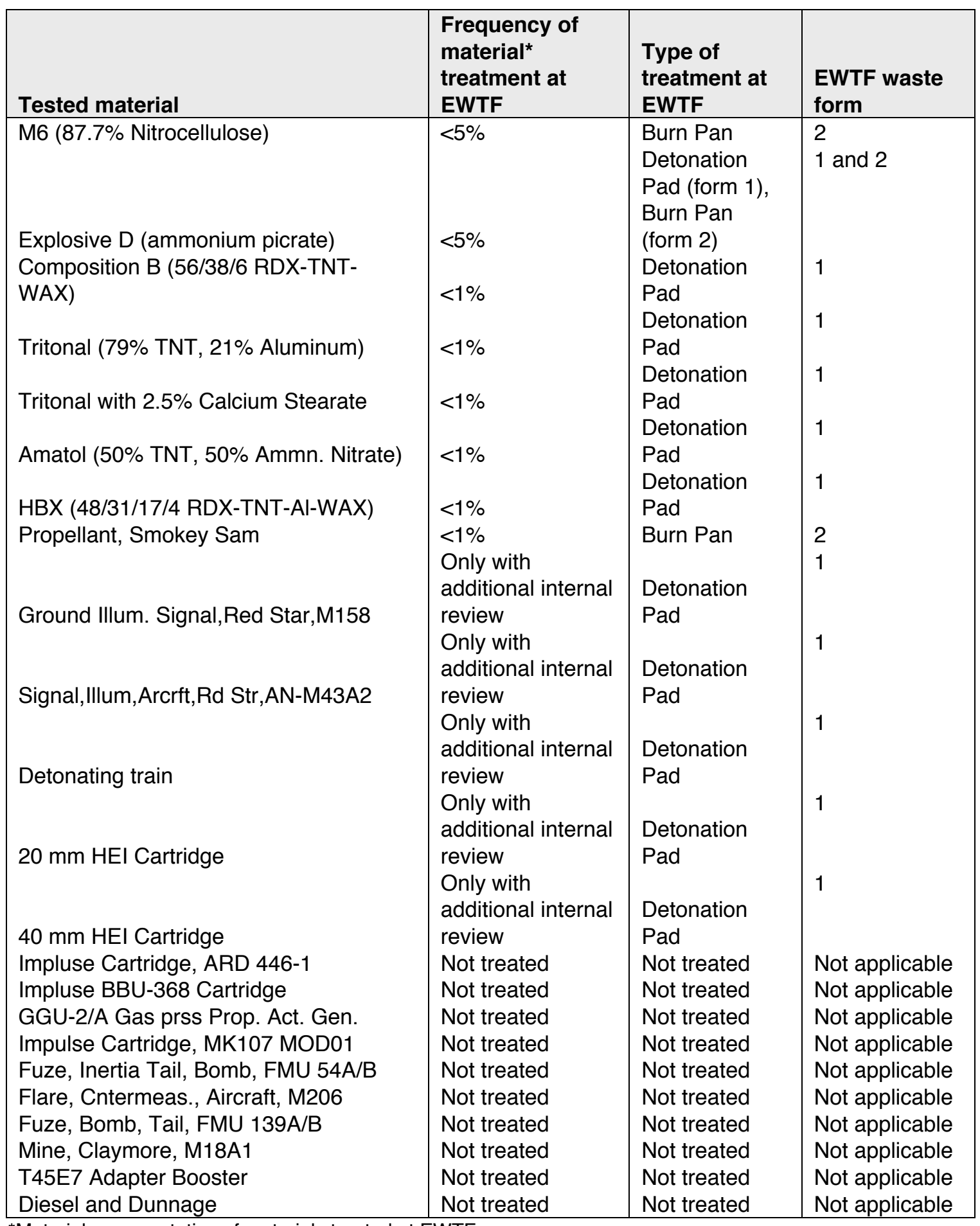

*Material representative of materials treated at EWTF. 
Table 3. Emissions factors for the burn pan, burn cage, and detonation pad at the EWTF.

\begin{tabular}{|c|c|c|c|c|}
\hline Analyte ID & Analyte Name & $\begin{array}{c}\text { Burn Pan } \\
\text { Emission } \\
\text { Factor (lb/lb) }\end{array}$ & $\begin{array}{c}\text { Burn Cage } \\
\text { Emission } \\
\text { Factor (lb/lb) }\end{array}$ & $\begin{array}{c}\text { Detonation } \\
\text { Pad } \\
\text { Emission } \\
\text { Factor (lb/lb) }\end{array}$ \\
\hline 67562-39-4 & 1234678-Heptachlorodibenzofuran & & 3.40E-08 & \\
\hline $55673-89-7$ & 1234789-Heptachlorodibenzofuran & & 7.90E-09 & \\
\hline $70648-26-9$ & 123478-Hexachlorodibenzofuran & & 2.10E-08 & \\
\hline $57117-44-9$ & 123678-Hexachlorodibenzofuran & & 9.50E-09 & \\
\hline $35822-46-9$ & Total Heptachlorodibenzo-p-dioxin & & & $6.10 \mathrm{E}-10$ \\
\hline $39001-02-0$ & Octachlorinated dibenzofuran & & 4.00E-08 & \\
\hline $106-99-0$ & 1,3-Butadiene & $1.70 \mathrm{E}-06$ & & $1.20 \mathrm{E}-05$ \\
\hline $121-14-2$ & 2,4-Dinitrotoluene & 1.20E-09 & & \\
\hline $606-20-2$ & 2,6-Dinitrotoluene & $1.00 \mathrm{E}-10$ & & \\
\hline $95-57-8$ & 2-Chlorophenol & $1.00 \mathrm{E}-05$ & & \\
\hline $107-05-1$ & Allyl Chloride & & & $1.80 \mathrm{E}-05$ \\
\hline $7429-90-5$ & Aluminum & 1.10E-02 & 3.60E-02 & 2.50E-02 \\
\hline $7440-36-0$ & Antimony & $6.70 \mathrm{E}-07$ & & $6.70 \mathrm{E}-07$ \\
\hline $7440-39-3$ & Barium & 8.20E-03 & 8.60E-05 & 8.20E-03 \\
\hline $71-43-2$ & Benzene & $1.20 \mathrm{E}-04$ & 4.50E-04 & 1.10E-04 \\
\hline $7440-43-9$ & Cadmium & 4.00E-05 & & $1.10 \mathrm{E}-03^{\circ}$ \\
\hline $56-23-5$ & Carbon Tetrachloride & 1.10E-06 & 5.60E-06 & 7.60E-06 \\
\hline $67-66-3$ & Chloroform & 4.20E-07 & 2.30E-06 & $3.80 \mathrm{E}-07$ \\
\hline $7440-47-3$ & Chromium & 4.80E-05 & & $1.50 \mathrm{E}-04$ \\
\hline $7782-50-5$ & $\mathrm{Cl} 2$ & $9.20 \mathrm{E}-03$ & 2.00E-04 & \\
\hline $630-08-0$ & $\mathrm{CO}$ & 7.20E-02 & 2.00E-02 & $1.10 \mathrm{E}-01$ \\
\hline $7440-50-8$ & Copper & 3.70E-02 & $1.50 \mathrm{E}-05$ & 2.60E-02 \\
\hline $110-82-7$ & Cyclohexane & $1.60 \mathrm{E}-06$ & 2.00E-06 & 7.50E-06 \\
\hline $84-66-2$ & Diethyl phthalate & & & 7.70E-05 \\
\hline $122-39-4$ & Diphenylamine & $2.60 \mathrm{E}-10$ & & \\
\hline $75-00-3$ & Ethyl chloride & & & $6.90 \mathrm{E}-07$ \\
\hline $100-41-4$ & Ethylbenzene & $1.20 \mathrm{E}-06$ & $2.40 \mathrm{E}-06$ & 4.60E-06 \\
\hline $206-44-0$ & Fluoranthene & & 2.00E-04 & \\
\hline $7647-01-0$ & $\mathrm{HCL}$ & $2.15 \mathrm{E}-01$ & 8.30E-02 & \\
\hline $98-82-8$ & i-Propylbenzene & & & 7.30E-07 \\
\hline $7439-92-1$ & Lead & $1.20 \mathrm{E}-02$ & 2.80E-04 & 1.10E-03 \\
\hline $74-87-3$ & Methyl Chloride & 5.70E-06 & 2.00E-05 & $1.70 \mathrm{E}-06$ \\
\hline $71-55-6$ & Methyl chloroform & & & 3.30E-06 \\
\hline $108-87-2$ & Methylcyclohexane & $5.10 \mathrm{E}-06$ & 8.00E-06 & 7.00E-06 \\
\hline $75-09-2$ & Methylenechloride & $1.80 \mathrm{E}-04$ & $1.20 \mathrm{E}-05$ & 8.70E-04 \\
\hline $91-20-3$ & Naphthalene & 7.50E-08 & & \\
\hline $110-54-3$ & n-Hexane & 1.90E-05 & $4.80 E-06$ & $1.90 \mathrm{E}-05$ \\
\hline $10102-44-0$ & Nitrogen Dioxide (peroxide) & $5.20 \mathrm{E}-03$ & $6.60 \mathrm{E}-06$ & $4.40 \mathrm{E}-03$ \\
\hline $78-11-5$ & Pentaerythritol tetranitrate (PETN) & & & 5.60E-04 \\
\hline $108-95-2$ & Phenol & 3.43E-09 & & \\
\hline $115-07-1$ & Propene & $7.20 \mathrm{E}-06$ & $2.60 \mathrm{E}-05$ & 7.30E-05 \\
\hline $121-82-4$ & $\mathrm{RDX}$ & $9.60 \mathrm{E}-06$ & & 7.40E-03 \\
\hline $100-42-5$ & Styrene & $1.50 \mathrm{E}-06$ & & $4.20 \mathrm{E}-05$ \\
\hline $7446-09-5$ & Sulfur Dioxide & $3.20 \mathrm{E}-03$ & 8.60E-04 & $1.30 \mathrm{E}-02$ \\
\hline $127-18-4$ & Tetrachloroethylene & & $1.70 \mathrm{E}-06$ & $1.80 \mathrm{E}-05$ \\
\hline $108-88-3$ & Toluene & 8.60E-06 & 2.80E-05 & 3.00E-05 \\
\hline $75-01-4$ & Vinyl Chloride & $1.50 \mathrm{E}-06$ & & 2.30E-06 \\
\hline
\end{tabular}




\begin{tabular}{|l|l|c|c|c|}
\hline Analyte ID & Analyte Name & $\begin{array}{c}\text { Burn Pan } \\
\text { Emission } \\
\text { Factor (Ib/lb) }\end{array}$ & $\begin{array}{c}\text { Burn Cage } \\
\text { Emission } \\
\text { Factor (Ib/lb) }\end{array}$ & $\begin{array}{c}\text { Detonation } \\
\text { Pad } \\
\text { Emission } \\
\text { Factor (Ib/lb) }\end{array}$ \\
\hline $7440-66-6$ & Zinc & $4.00 \mathrm{E}-05$ & $5.70 \mathrm{E}-04$ & $1.60 \mathrm{E}-02$ \\
$208-96-8$ & Acenaphthylene & $1.40 \mathrm{E}-10$ & $1.60 \mathrm{E}-04$ & \\
$86-57-7$ & n-Nitronaphthalene & $2.00 \mathrm{E}-06$ & $2.60 \mathrm{E}-06$ & $3.70 \mathrm{E}-06$ \\
$620-14-4$ & m-Ethyltoluene & $7.10 \mathrm{E}-06$ & $5.00 \mathrm{E}-06$ & $1.40 \mathrm{E}-05$ \\
$622-96-8$ & p-Ethyltoluene & $1.60 \mathrm{E}-06$ & $8.30 \mathrm{E}-06$ & $3.10 \mathrm{E}-05$ \\
$106-98-9$ & 1-Butene & & & $2.40 \mathrm{E}-05$ \\
$592-41-6$ & 1-Hexene & $1.40 \mathrm{E}-06$ & $5.10 \mathrm{E}-06$ & $1.40 \mathrm{E}-05$ \\
$109-67-1$ & 1-Pentene & $8.30 \mathrm{E}-04$ & $1.60 \mathrm{E}-03$ & $3.10 \mathrm{E}-04$ \\
$74-86-2$ & Acetylene & $4.60 \mathrm{E}-07$ & $5.60 \mathrm{E}-07$ & $8.30 \mathrm{E}-07$ \\
$627-20-3$ & cis-2-Pentene & $4.70 \mathrm{E}-07$ & $2.50 \mathrm{E}-07$ & $1.70 \mathrm{E}-06$ \\
$287-92-3$ & Cyclopentane & $4.60 \mathrm{E}-07$ & $9.40 \mathrm{E}-07$ & $3.70 \mathrm{E}-06$ \\
$142-29-0$ & Cyclopentene & $1.30 \mathrm{E}-06$ & $9.50 \mathrm{E}-06$ & $9.40 \mathrm{E}-05$ \\
$74-84-0$ & Ethane & $7.20 \mathrm{E}-05$ & $2.30 \mathrm{E}-04$ & $3.90 \mathrm{E}-04$ \\
$74-85-1$ & Ethylene & $4.60 \mathrm{E}-07$ & $1.40 \mathrm{E}-06$ & $1.60 \mathrm{E}-06$ \\
$75-28-5$ & i-Butane & $1.00 \mathrm{E}-05$ & $5.80 \mathrm{E}-06$ & $2.40 \mathrm{E}-05$ \\
$115-11-7$ & i-Butene & $2.60 \mathrm{E}-06$ & $2.30 \mathrm{E}-05$ & $1.20 \mathrm{E}-05$ \\
$78-78-4$ & i-Pentane & $8.00 \mathrm{E}-03$ & & $2.40 \mathrm{E}-03$ \\
$74-82-8$ & Methane & $2.50 \mathrm{E}-06$ & $1.10 \mathrm{E}-06$ & $9.10 \mathrm{E}-06$ \\
$96-37-7$ & Methylcyclopentane & $4.80 \mathrm{E}-07$ & $9.30 \mathrm{E}-06$ & $7.40 \mathrm{E}-06$ \\
$106-97-8$ & n-Butane & $5.90 \mathrm{E}-06$ & $1.40 \mathrm{E}-05$ & $6.50 \mathrm{E}-06$ \\
$124-18-5$ & n-Decane & $2.00 \mathrm{E}-06$ & $4.70 \mathrm{E}-06$ & $5.30 \mathrm{E}-06$ \\
$142-82-5$ & n-Heptane & $1.20 \mathrm{E}-06$ & $1.30 \mathrm{E}-05$ & $1.90 \mathrm{E}-06$ \\
$111-84-2$ & n-Nonane & $2.90 \mathrm{E}-06$ & $7.60 \mathrm{E}-06$ & $9.50 \mathrm{E}-06$ \\
$111-65-9$ & n-Octane & $3.30 \mathrm{E}-06$ & $4.30 \mathrm{E}-06$ & $1.30 \mathrm{E}-05$ \\
$109-66-0$ & n-Pentane & $1.60 \mathrm{E}-06$ & $4.50 \mathrm{E}-06$ & $1.30 \mathrm{E}-05$ \\
$74-98-6$ & Propane & $2.40 \mathrm{E}-06$ & $2.10 \mathrm{E}-05$ & $9.50 \mathrm{E}-06$ \\
$624-64-6$ & trans-2-Butene & $4.60 \mathrm{E}-07$ & $9.60 \mathrm{E}-07$ & $5.00 \mathrm{E}-06$ \\
\hline $646-04-8$ & trans-2-Pentene & & \\
\hline
\end{tabular}

* The maximum value 0.0011 was used to calculate maximum hourly cadmium emissions. The frequency of treatment-weighted emission factor of 5.90E-05 (see Table 4 for its derivation) was used to calculate the annual average cadmium emissions.

Table 4. Calculation of the emission factor for cadmium for detonation pad.

\begin{tabular}{|l|c|c|c|}
\hline Material & $\begin{array}{c}\text { Percent } \\
\text { Frequency }\end{array}$ & $\begin{array}{c}\text { OBODM emission } \\
\text { factor }\end{array}$ & Weighted emission factor \\
\hline $\begin{array}{l}\text { Ground Illumination Signal, } \\
\text { Red Star, M158 }\end{array}$ & 1 & 0.0011 & 0.000011 \\
20 mm HEI Cartridge & 1 & 0.00086 & 0.0000086 \\
Signal, Illumination Aircraft, & 1 & 0.000088 & 0.00000088 \\
Red Star, AN-M43A2 & 97 & 0.00004 & 0.000039 \\
TNT (2,4,6-Trinitrotoluene) & & Final emission factor & $\mathbf{0 . 0 0 0 0 5 9}$ \\
\hline
\end{tabular}


Also worthy of comment is the selection of emissions factors to represent Form 4 waste. The treatment of Form 4 waste in the burn cage was represented by the Bjorklund et al. (1998) emissions factors for AP manufacturing waste surrogate. The AP manufacturing waste surrogate included plastic gloves, cotton rags, paper, wood, and similar material, and was burned using diesel fuel (Mitchell and Suggs, 1998). The burn cage at the EWTF does not use diesel fuel, rather it uses propane, and there is every expectation that the combustion temperatures of propane minimize dioxin and furan formation; nevertheless, they are included for purposes of conservatism. Among the possible materials that could be used to represent Form 4 waste, the AP manufacturing waste surrogate is the most reasonable choice.

The resulting maximum hourly and annual average emissions for each waste form are shown in Tables 5 and 6 . Although only a total of 100 burn treatments are permitted, all burn operations were calculated at 100 burns per year at this point in the assessment to enable comparison of effects later in the analysis.

Table 5. Maximum hourly estimated emissions for the burn pan, burn cage (Forms 3 and 4), and detonation pad at the EWTF.

\begin{tabular}{|c|c|c|c|c|c|}
\hline Analyte ID & Analyte Name & $\begin{array}{l}\text { Burn } \\
\text { Pan }\end{array}$ & $\begin{array}{c}\text { Burn } \\
\text { Cage } \\
\text { Form } 3\end{array}$ & $\begin{array}{c}\text { Burn } \\
\text { Cage } \\
\text { Form } 4\end{array}$ & $\begin{array}{c}\text { Detonation } \\
\text { Pad }\end{array}$ \\
\hline $67562-39-4$ & 1234678-HpCDF & $0.00 \mathrm{E}+00$ & 1.70E-06 & 8.84E-06 & $0.00 \mathrm{E}+00$ \\
\hline 55673-89-7 & 1234789-HpCDF & $0.00 \mathrm{E}+00$ & 3.95E-07 & 2.05E-06 & $0.00 \mathrm{E}+00$ \\
\hline 70648-26-9 & 123478-HxCDF & $0.00 \mathrm{E}+00$ & 1.05E-06 & $5.46 \mathrm{E}-06$ & $0.00 \mathrm{E}+00$ \\
\hline $57117-44-9$ & 123678-HxCDF & $0.00 \mathrm{E}+00$ & $4.75 \mathrm{E}-07$ & $2.47 \mathrm{E}-06$ & $0.00 \mathrm{E}+00$ \\
\hline $35822-46-9$ & Total HpCDD & $0.00 E+00$ & $0.00 E+00$ & $0.00 E+00$ & 2.14E-07 \\
\hline $39001-02-0$ & OCDF & $0.00 \mathrm{E}+00$ & 2.00E-06 & $1.04 \mathrm{E}-05$ & $0.00 \mathrm{E}+00$ \\
\hline $106-99-0$ & 1,3-Butadiene & $1.70 \mathrm{E}-04$ & $0.00 \mathrm{E}+00$ & $0.00 \mathrm{E}+00$ & 4.20E-03 \\
\hline $121-14-2$ & 2,4-Dinitrotoluene & 1.20E-07 & $0.00 \mathrm{E}+00$ & $0.00 \mathrm{E}+00$ & $0.00 \mathrm{E}+00$ \\
\hline $606-20-2$ & 2,6-Dinitrotoluene & 1.00E-08 & $0.00 E+00$ & $0.00 E+00$ & $0.00 \mathrm{E}+00$ \\
\hline $95-57-8$ & 2-Chlorophenol & 1.00E-03 & $0.00 E+00$ & $0.00 \mathrm{E}+00$ & $0.00 \mathrm{E}+00$ \\
\hline $107-05-1$ & Allyl Chloride & $0.00 \mathrm{E}+00$ & $0.00 E+00$ & $0.00 \mathrm{E}+00$ & $6.30 \mathrm{E}-03$ \\
\hline $7429-90-5$ & Aluminum & $1.10 \mathrm{E}+00$ & $1.80 \mathrm{E}+00$ & $9.36 \mathrm{E}+00$ & $8.75 \mathrm{E}+00$ \\
\hline $7440-36-0$ & Antimony & $6.70 \mathrm{E}-05$ & $0.00 \mathrm{E}+00$ & $0.00 \mathrm{E}+00$ & 2.35E-04 \\
\hline $7440-39-3$ & Barium & $8.20 \mathrm{E}-01$ & 4.30E-03 & $2.24 \mathrm{E}-02$ & $2.87 \mathrm{E}+00$ \\
\hline $71-43-2$ & Benzene & 1.20E-02 & $2.25 \mathrm{E}-02$ & 1.17E-01 & $3.85 \mathrm{E}-02$ \\
\hline $7440-43-9$ & Cadmium & $4.00 \mathrm{E}-03$ & $0.00 E+00$ & $0.00 \mathrm{E}+00$ & 3.85E-01 \\
\hline $56-23-5$ & Carbon Tetrachloride & 1.10E-04 & $2.80 \mathrm{E}-04$ & 1.46E-03 & 2.66E-03 \\
\hline $67-66-3$ & Chloroform & $4.20 \mathrm{E}-05$ & 1.15E-04 & 5.98E-04 & 1.33E-04 \\
\hline $7440-47-3$ & Chromium & 4.80E-03 & $0.00 \mathrm{E}+00$ & $0.00 \mathrm{E}+00$ & $5.25 E-02$ \\
\hline $7782-50-5$ & $\mathrm{Cl} 2$ & $9.20 \mathrm{E}-01$ & 1.00E-02 & $5.20 \mathrm{E}-02$ & $0.00 \mathrm{E}+00$ \\
\hline $630-08-0$ & $\mathrm{CO}$ & $7.20 \mathrm{E}+00$ & $1.00 E+00$ & $5.20 \mathrm{E}+00$ & $3.85 \mathrm{E}+01$ \\
\hline $7440-50-8$ & Copper & $3.70 \mathrm{E}+00$ & 7.50E-04 & 3.90E-03 & $9.10 \mathrm{E}+00$ \\
\hline $110-82-7$ & Cyclohexane & 1.60E-04 & 1.00E-04 & $5.20 \mathrm{E}-04$ & 2.63E-03 \\
\hline 84-66-2 & Diethyl phthalate & $0.00 \mathrm{E}+00$ & $0.00 E+00$ & $0.00 \mathrm{E}+00$ & 2.70E-02 \\
\hline $122-39-4$ & Diphenylamine & 2.60E-08 & $0.00 E+00$ & $0.00 \mathrm{E}+00$ & $0.00 \mathrm{E}+00$ \\
\hline $75-00-3$ & Ethyl chloride & $0.00 \mathrm{E}+00$ & $0.00 E+00$ & $0.00 \mathrm{E}+00$ & 2.42E-04 \\
\hline $100-41-4$ & Ethylbenzene & 1.20E-04 & 1.20E-04 & $6.24 \mathrm{E}-04$ & 1.61E-03 \\
\hline $206-44-0$ & Fluoranthene & $0.00 \mathrm{E}+00$ & 1.00E-02 & $5.20 \mathrm{E}-02$ & $0.00 \mathrm{E}+00$ \\
\hline
\end{tabular}




\begin{tabular}{|c|c|c|c|c|c|}
\hline Analyte ID & Analyte Name & $\begin{array}{l}\text { Burn } \\
\text { Pan }\end{array}$ & $\begin{array}{c}\text { Burn } \\
\text { Cage } \\
\text { Form } 3\end{array}$ & $\begin{array}{c}\text { Burn } \\
\text { Cage } \\
\text { Form } 4\end{array}$ & $\begin{array}{c}\text { Detonation } \\
\text { Pad }\end{array}$ \\
\hline $7647-01-0$ & $\mathrm{HCL}$ & $2.15 \mathrm{E}+01$ & $4.15 E+00$ & $2.16 \mathrm{E}+01$ & $0.00 \mathrm{E}+00$ \\
\hline $98-82-8$ & i-Propylbenzene & $0.00 \mathrm{E}+00$ & $0.00 \mathrm{E}+00$ & $0.00 E+00$ & $2.56 \mathrm{E}-04$ \\
\hline $7439-92-1$ & Lead & $1.20 \mathrm{E}+00$ & 1.40E-02 & $7.28 \mathrm{E}-02$ & 3.85E-01 \\
\hline $74-87-3$ & Methyl Chloride & $5.70 \mathrm{E}-04$ & 1.00E-03 & $5.20 \mathrm{E}-03$ & 5.95E-04 \\
\hline $71-55-6$ & Methyl chloroform & $0.00 E+00$ & $0.00 E+00$ & $0.00 E+00$ & 1.16E-03 \\
\hline $108-87-2$ & Methylcyclohexane & $5.10 \mathrm{E}-04$ & 4.00E-04 & 2.08E-03 & 2.45E-03 \\
\hline $75-09-2$ & Methylenechloride & $1.80 \mathrm{E}-02$ & 6.00E-04 & $3.12 \mathrm{E}-03$ & 3.05E-01 \\
\hline $91-20-3$ & Naphthalene & $7.50 \mathrm{E}-06$ & $0.00 E+00$ & $0.00 E+00$ & $0.00 E+00$ \\
\hline $110-54-3$ & $\begin{array}{l}\mathrm{n} \text {-Hexane } \\
\text { Nitrogen Dioxide }\end{array}$ & $1.90 \mathrm{E}-03$ & $2.40 \mathrm{E}-04$ & $1.25 \mathrm{E}-03$ & $6.65 \mathrm{E}-03$ \\
\hline $10102-44-0$ & $\begin{array}{l}\text { (peroxide) } \\
\text { Pentaerythritol }\end{array}$ & $5.20 \mathrm{E}-01$ & 3.30E-04 & $1.72 \mathrm{E}-03$ & $1.54 \mathrm{E}+00$ \\
\hline $78-11-5$ & tetranitrate (PETN) & $0.00 \mathrm{E}+00$ & $0.00 E+00$ & $0.00 E+00$ & 1.96E-01 \\
\hline $108-95-2$ & Phenol & $3.43 E-07$ & $0.00 E+00$ & $0.00 E+00$ & $0.00 E+00$ \\
\hline $115-07-1$ & Propene & $7.20 \mathrm{E}-04$ & 1.30E-03 & 6.76E-03 & 2.56E-02 \\
\hline $121-82-4$ & RDX & $9.60 \mathrm{E}-04$ & $0.00 E+00$ & $0.00 E+00$ & $2.59 \mathrm{E}+00$ \\
\hline $100-42-5$ & Styrene & $1.50 \mathrm{E}-04$ & $0.00 E+00$ & $0.00 E+00$ & 1.47E-02 \\
\hline $7446-09-5$ & Sulfur Dioxide & $3.20 \mathrm{E}-01$ & 4.30E-02 & $2.24 \mathrm{E}-01$ & $4.55 \mathrm{E}+00$ \\
\hline $127-18-4$ & Tetrachloroethylene & $0.00 \mathrm{E}+00$ & 8.50E-05 & $4.42 \mathrm{E}-04$ & 6.30E-03 \\
\hline $108-88-3$ & Toluene & 8.60E-04 & 1.40E-03 & $7.28 \mathrm{E}-03$ & 1.05E-02 \\
\hline $75-01-4$ & Vinyl Chloride & $1.50 \mathrm{E}-04$ & $0.00 E+00$ & $0.00 E+00$ & 8.05E-04 \\
\hline $7440-66-6$ & Zinc & 4.00E-03 & 2.85E-02 & $1.48 \mathrm{E}-01$ & $5.60 \mathrm{E}+00$ \\
\hline $208-96-8$ & Acenaphthylene & $0.00 \mathrm{E}+00$ & 8.00E-03 & 4.16E-02 & $0.00 E+00$ \\
\hline $86-57-7$ & n-Nitronaphthalene & $1.40 \mathrm{E}-08$ & $0.00 E+00$ & $0.00 \mathrm{E}+00$ & $0.00 E+00$ \\
\hline $620-14-4$ & m-Ethyltoluene & $2.00 \mathrm{E}-04$ & 1.30E-04 & 6.76E-04 & $1.30 \mathrm{E}-03$ \\
\hline $622-96-8$ & p-Ethyltoluene & $7.10 \mathrm{E}-04$ & $2.50 \mathrm{E}-04$ & $1.30 \mathrm{E}-03$ & $4.90 \mathrm{E}-03$ \\
\hline $106-98-9$ & 1-Butene & 1.60E-04 & $4.15 \mathrm{E}-04$ & 2.16E-03 & 1.09E-02 \\
\hline $592-41-6$ & 1-Hexene & $0.00 E+00$ & $0.00 E+00$ & $0.00 E+00$ & 8.40E-03 \\
\hline $109-67-1$ & 1-Pentene & $1.40 \mathrm{E}-04$ & $2.55 \mathrm{E}-04$ & $1.33 \mathrm{E}-03$ & $4.90 \mathrm{E}-03$ \\
\hline $74-86-2$ & Acetylene & 8.30E-02 & 8.00E-02 & 4.16E-01 & $1.09 \mathrm{E}-01$ \\
\hline $627-20-3$ & cis-2-Pentene & 4.60E-05 & $2.80 \mathrm{E}-05$ & $1.46 \mathrm{E}-04$ & 2.91E-04 \\
\hline $287-92-3$ & Cyclopentane & 4.70E-05 & $1.25 \mathrm{E}-05$ & $6.50 \mathrm{E}-05$ & $5.95 E-04$ \\
\hline $142-29-0$ & Cyclopentene & 4.60E-05 & 4.70E-05 & 2.44E-04 & 1.30E-03 \\
\hline $74-84-0$ & Ethane & 1.30E-04 & $4.75 \mathrm{E}-04$ & $2.47 \mathrm{E}-03$ & $3.29 \mathrm{E}-02$ \\
\hline $74-85-1$ & Ethylene & $7.20 \mathrm{E}-03$ & 1.15E-02 & $5.98 \mathrm{E}-02$ & 1.37E-01 \\
\hline $75-28-5$ & i-Butane & 4.60E-05 & 7.00E-05 & $3.64 \mathrm{E}-04$ & $5.60 \mathrm{E}-04$ \\
\hline $115-11-7$ & i-Butene & 1.00E-03 & $2.90 \mathrm{E}-04$ & 1.51E-03 & 8.40E-03 \\
\hline $78-78-4$ & i-Pentane & $2.60 \mathrm{E}-04$ & 1.15E-03 & $5.98 \mathrm{E}-03$ & $4.20 \mathrm{E}-03$ \\
\hline $74-82-8$ & Methane & 8.00E-01 & $0.00 E+00$ & $0.00 E+00$ & 8.40E-01 \\
\hline $96-37-7$ & Methylcyclopentane & $2.50 \mathrm{E}-04$ & 5.50E-05 & $2.86 \mathrm{E}-04$ & $3.19 \mathrm{E}-03$ \\
\hline $106-97-8$ & n-Butane & 4.80E-05 & 4.65E-04 & $2.42 \mathrm{E}-03$ & 2.59E-03 \\
\hline $124-18-5$ & n-Decane & 5.90E-04 & 7.00E-04 & 3.64E-03 & 2.28E-03 \\
\hline $142-82-5$ & n-Heptane & $2.00 \mathrm{E}-04$ & 2.35E-04 & $1.22 \mathrm{E}-03$ & 1.86E-03 \\
\hline $111-84-2$ & n-Nonane & $1.20 \mathrm{E}-04$ & $6.50 \mathrm{E}-04$ & $3.38 \mathrm{E}-03$ & 6.65E-04 \\
\hline $111-65-9$ & n-Octane & $2.90 \mathrm{E}-04$ & 3.80E-04 & $1.98 \mathrm{E}-03$ & 3.33E-03 \\
\hline $109-66-0$ & n-Pentane & 3.30E-04 & 2.15E-04 & 1.12E-03 & 4.55E-03 \\
\hline $74-98-6$ & Propane & 1.60E-04 & 2.25E-04 & 1.17E-03 & 4.55E-03 \\
\hline $624-64-6$ & trans-2-Butene & $2.40 \mathrm{E}-04$ & 1.05E-03 & $5.46 \mathrm{E}-03$ & 3.33E-03 \\
\hline $646-04-8$ & trans-2-Pentene & 4.60E-05 & 4.80E-05 & 2.50E-04 & $1.75 \mathrm{E}-03$ \\
\hline
\end{tabular}


Table 6. Maximum annual estimated emissions for the burn pan, burn cage (Forms 3 and 4), and detonation pad) at the EWTF

\begin{tabular}{|c|c|c|c|c|c|}
\hline Analyte ID & Analyte Name & $\begin{array}{l}\text { Burn } \\
\text { Pan }\end{array}$ & $\begin{array}{c}\text { Burn } \\
\text { Cage } \\
\text { Form } 3 \\
\end{array}$ & $\begin{array}{c}\text { Burn } \\
\text { Cage } \\
\text { Form } 4 \\
\end{array}$ & $\begin{array}{c}\text { Detonation } \\
\text { Pad }\end{array}$ \\
\hline $67562-39-4$ & 1234678-HpCDF & $0.00 \mathrm{E}+00$ & 1.70E-04 & 8.84E-04 & $0.00 \mathrm{E}+00$ \\
\hline 55673-89-7 & 1234789-HpCDF & $0.00 \mathrm{E}+00$ & 3.95E-05 & 2.05E-04 & $0.00 \mathrm{E}+00$ \\
\hline 70648-26-9 & 123478-HxCDF & $0.00 \mathrm{E}+00$ & 1.05E-04 & $5.46 \mathrm{E}-04$ & $0.00 \mathrm{E}+00$ \\
\hline $57117-44-9$ & 123678-HxCDF & $0.00 E+00$ & 4.75E-05 & 2.47E-04 & $0.00 E+00$ \\
\hline $35822-46-9$ & Total HpCDD & $0.00 E+00$ & $0.00 E+00$ & $0.00 E+00$ & 2.14E-05 \\
\hline $39001-02-0$ & OCDF & $0.00 \mathrm{E}+00$ & $2.00 \mathrm{E}-04$ & 1.04E-03 & $0.00 \mathrm{E}+00$ \\
\hline $106-99-0$ & 1,3-Butadiene & 1.70E-02 & $0.00 \mathrm{E}+00$ & $0.00 \mathrm{E}+00$ & $4.20 \mathrm{E}-01$ \\
\hline $121-14-2$ & 2,4-Dinitrotoluene & $1.20 \mathrm{E}-05$ & $0.00 \mathrm{E}+00$ & $0.00 \mathrm{E}+00$ & $0.00 \mathrm{E}+00$ \\
\hline $606-20-2$ & 2,6-Dinitrotoluene & $1.00 \mathrm{E}-06$ & $0.00 E+00$ & $0.00 E+00$ & $0.00 E+00$ \\
\hline $95-57-8$ & 2-Chlorophenol & $1.00 \mathrm{E}-01$ & $0.00 E+00$ & $0.00 E+00$ & $0.00 E+00$ \\
\hline $107-05-1$ & Allyl Chloride & $0.00 \mathrm{E}+00$ & $0.00 E+00$ & $0.00 E+00$ & $6.30 \mathrm{E}-01$ \\
\hline $7429-90-5$ & Aluminum & $1.10 \mathrm{E}+02$ & $1.80 E+02$ & $9.36 \mathrm{E}+02$ & $8.75 \mathrm{E}+02$ \\
\hline $7440-36-0$ & Antimony & $6.70 \mathrm{E}-03$ & $0.00 E+00$ & $0.00 E+00$ & $2.35 \mathrm{E}-02$ \\
\hline $7440-39-3$ & Barium & $8.20 \mathrm{E}+01$ & 4.30E-01 & $2.24 \mathrm{E}+00$ & $2.87 \mathrm{E}+02$ \\
\hline $71-43-2$ & Benzene & $1.20 \mathrm{E}+00$ & $2.25 \mathrm{E}+00$ & $1.17 \mathrm{E}+01$ & $3.85 \mathrm{E}+00$ \\
\hline 7440-43-9 & Cadmium & 4.00E-01 & $0.00 \mathrm{E}+00$ & $0.00 \mathrm{E}+00$ & $2.07 \mathrm{E}+00$ \\
\hline $56-23-5$ & Carbon Tetrachloride & 1.10E-02 & $2.80 \mathrm{E}-02$ & 1.46E-01 & 2.66E-01 \\
\hline $67-66-3$ & Chloroform & $4.20 \mathrm{E}-03$ & 1.15E-02 & $5.98 \mathrm{E}-02$ & 1.33E-02 \\
\hline $7440-47-3$ & Chromium & $4.80 \mathrm{E}-01$ & $0.00 \mathrm{E}+00$ & $0.00 \mathrm{E}+00$ & $5.25 \mathrm{E}+00$ \\
\hline $7782-50-5$ & $\mathrm{Cl} 2$ & $9.20 \mathrm{E}+01$ & $1.00 \mathrm{E}+00$ & $5.20 \mathrm{E}+00$ & $0.00 E+00$ \\
\hline $630-08-0$ & $\mathrm{CO}$ & $7.20 \mathrm{E}+02$ & $1.00 \mathrm{E}+02$ & $5.20 \mathrm{E}+02$ & $3.85 E+03$ \\
\hline $7440-50-8$ & Copper & $3.70 \mathrm{E}+02$ & 7.50E-02 & 3.90E-01 & $9.10 \mathrm{E}+02$ \\
\hline $110-82-7$ & Cyclohexane & $1.60 \mathrm{E}-02$ & 1.00E-02 & $5.20 \mathrm{E}-02$ & 2.63E-01 \\
\hline $84-66-2$ & Diethyl phthalate & $0.00 \mathrm{E}+00$ & $0.00 E+00$ & $0.00 \mathrm{E}+00$ & $2.70 \mathrm{E}+00$ \\
\hline $122-39-4$ & Diphenylamine & $2.60 \mathrm{E}-06$ & $0.00 E+00$ & $0.00 \mathrm{E}+00$ & $0.00 \mathrm{E}+00$ \\
\hline $75-00-3$ & Ethyl chloride & $0.00 \mathrm{E}+00$ & $0.00 E+00$ & $0.00 \mathrm{E}+00$ & $2.42 \mathrm{E}-02$ \\
\hline $100-41-4$ & Ethylbenzene & $1.20 \mathrm{E}-02$ & 1.20E-02 & $6.24 \mathrm{E}-02$ & $1.61 \mathrm{E}-01$ \\
\hline $206-44-0$ & Fluoranthene & $0.00 \mathrm{E}+00$ & $1.00 \mathrm{E}+00$ & $5.20 \mathrm{E}+00$ & $0.00 \mathrm{E}+00$ \\
\hline $7647-01-0$ & $\mathrm{HCL}$ & $2.15 \mathrm{E}+03$ & $4.15 E+02$ & $2.16 \mathrm{E}+03$ & $0.00 \mathrm{E}+00$ \\
\hline $98-82-8$ & i-Propylbenzene & $0.00 \mathrm{E}+00$ & $0.00 E+00$ & $0.00 \mathrm{E}+00$ & $2.56 \mathrm{E}-02$ \\
\hline $7439-92-1$ & Lead & $1.20 \mathrm{E}+02$ & $1.40 E+00$ & $7.28 \mathrm{E}+00$ & $3.85 E+01$ \\
\hline $74-87-3$ & Methyl Chloride & $5.70 \mathrm{E}-02$ & 1.00E-01 & 5.20E-01 & 5.95E-02 \\
\hline $71-55-6$ & Methyl chloroform & $0.00 \mathrm{E}+00$ & $0.00 E+00$ & $0.00 \mathrm{E}+00$ & 1.16E-01 \\
\hline $108-87-2$ & Methylcyclohexane & $5.10 \mathrm{E}-02$ & 4.00E-02 & 2.08E-01 & $2.45 E-01$ \\
\hline $75-09-2$ & Methylenechloride & $1.80 \mathrm{E}+00$ & 6.00E-02 & $3.12 \mathrm{E}-01$ & $3.05 E+01$ \\
\hline $91-20-3$ & Naphthalene & $7.50 \mathrm{E}-04$ & $0.00 E+00$ & $0.00 \mathrm{E}+00$ & $0.00 \mathrm{E}+00$ \\
\hline $110-54-3$ & $\begin{array}{l}\text { n-Hexane } \\
\text { Nitrogen Dioxide }\end{array}$ & $1.90 \mathrm{E}-01$ & 2.40E-02 & $1.25 \mathrm{E}-01$ & $6.65 \mathrm{E}-01$ \\
\hline $10102-44-0$ & $\begin{array}{l}\text { (peroxide) } \\
\text { Pentaerythritol }\end{array}$ & $5.20 \mathrm{E}+01$ & 3.30E-02 & $1.72 \mathrm{E}-01$ & $1.54 \mathrm{E}+02$ \\
\hline $78-11-5$ & tetranitrate (PETN) & $0.00 \mathrm{E}+00$ & $0.00 E+00$ & $0.00 E+00$ & $1.96 \mathrm{E}+01$ \\
\hline $108-95-2$ & Phenol & 3.43E-05 & $0.00 E+00$ & $0.00 E+00$ & $0.00 \mathrm{E}+00$ \\
\hline $115-07-1$ & Propene & 7.20E-02 & 1.30E-01 & 6.76E-01 & $2.56 \mathrm{E}+00$ \\
\hline $121-82-4$ & RDX & $9.60 \mathrm{E}-02$ & $0.00 E+00$ & $0.00 E+00$ & $2.59 \mathrm{E}+02$ \\
\hline $100-42-5$ & Styrene & $1.50 \mathrm{E}-02$ & $0.00 E+00$ & $0.00 E+00$ & $1.47 \mathrm{E}+00$ \\
\hline $7446-09-5$ & Sulfur Dioxide & $3.20 \mathrm{E}+01$ & $4.30 E+00$ & $2.24 \mathrm{E}+01$ & $4.55 \mathrm{E}+02$ \\
\hline $127-18-4$ & Tetrachloroethylene & $0.00 \mathrm{E}+00$ & 8.50E-03 & 4.42E-02 & $6.30 \mathrm{E}-01$ \\
\hline $108-88-3$ & Toluene & 8.60E-02 & 1.40E-01 & $7.28 \mathrm{E}-01$ & $1.05 \mathrm{E}+00$ \\
\hline
\end{tabular}




\begin{tabular}{|c|c|c|c|c|c|}
\hline Analyte ID & Analyte Name & $\begin{array}{l}\text { Burn } \\
\text { Pan }\end{array}$ & $\begin{array}{c}\text { Burn } \\
\text { Cage } \\
\text { Form } 3\end{array}$ & $\begin{array}{c}\text { Burn } \\
\text { Cage } \\
\text { Form } 4\end{array}$ & $\begin{array}{c}\text { Detonation } \\
\text { Pad }\end{array}$ \\
\hline $75-01-4$ & Vinyl Chloride & 1.50E-02 & $0.00 \mathrm{E}+00$ & $0.00 \mathrm{E}+00$ & 8.05E-02 \\
\hline $7440-66-6$ & Zinc & 4.00E-01 & $2.85 E+00$ & $1.48 E+01$ & $5.60 E+02$ \\
\hline $208-96-8$ & Acenaphthylene & $0.00 E+00$ & 8.00E-01 & $4.16 E+00$ & $0.00 E+00$ \\
\hline $86-57-7$ & n-Nitronaphthalene & $1.40 \mathrm{E}-06$ & $0.00 E+00$ & $0.00 E+00$ & $0.00 E+00$ \\
\hline $620-14-4$ & m-Ethyltoluene & 2.00E-02 & 1.30E-02 & $6.76 \mathrm{E}-02$ & 1.30E-01 \\
\hline $622-96-8$ & p-Ethyltoluene & 7.10E-02 & 2.50E-02 & $1.30 \mathrm{E}-01$ & 4.90E-01 \\
\hline $106-98-9$ & 1-Butene & 1.60E-02 & 4.15E-02 & 2.16E-01 & $1.09 E+00$ \\
\hline $592-41-6$ & 1-Hexene & $0.00 E+00$ & $0.00 E+00$ & $0.00 E+00$ & 8.40E-01 \\
\hline $109-67-1$ & 1-Pentene & 1.40E-02 & $2.55 E-02$ & 1.33E-01 & 4.90E-01 \\
\hline $74-86-2$ & Acetylene & $8.30 E+00$ & $8.00 E+00$ & $4.16 E+01$ & $1.09 E+01$ \\
\hline $627-20-3$ & cis-2-Pentene & 4.60E-03 & 2.80E-03 & $1.46 \mathrm{E}-02$ & 2.91E-02 \\
\hline $287-92-3$ & Cyclopentane & 4.70E-03 & $1.25 \mathrm{E}-03$ & $6.50 \mathrm{E}-03$ & 5.95E-02 \\
\hline $142-29-0$ & Cyclopentene & $4.60 \mathrm{E}-03$ & $4.70 \mathrm{E}-03$ & $2.44 \mathrm{E}-02$ & $1.30 \mathrm{E}-01$ \\
\hline $74-84-0$ & Ethane & $1.30 \mathrm{E}-02$ & $4.75 \mathrm{E}-02$ & $2.47 \mathrm{E}-01$ & $3.29 \mathrm{E}+00$ \\
\hline $74-85-1$ & Ethylene & $7.20 \mathrm{E}-01$ & $1.15 \mathrm{E}+00$ & $5.98 E+00$ & $1.37 \mathrm{E}+01$ \\
\hline $75-28-5$ & i-Butane & 4.60E-03 & 7.00E-03 & 3.64E-02 & $5.60 \mathrm{E}-02$ \\
\hline $115-11-7$ & i-Butene & $1.00 \mathrm{E}-01$ & $2.90 \mathrm{E}-02$ & $1.51 \mathrm{E}-01$ & 8.40E-01 \\
\hline $78-78-4$ & i-Pentane & $2.60 \mathrm{E}-02$ & $1.15 \mathrm{E}-01$ & $5.98 \mathrm{E}-01$ & $4.20 \mathrm{E}-01$ \\
\hline $74-82-8$ & Methane & $8.00 \mathrm{E}+01$ & $0.00 \mathrm{E}+00$ & $0.00 E+00$ & $8.40 \mathrm{E}+01$ \\
\hline $96-37-7$ & Methylcyclopentane & $2.50 \mathrm{E}-02$ & $5.50 \mathrm{E}-03$ & $2.86 \mathrm{E}-02$ & 3.19E-01 \\
\hline $106-97-8$ & n-Butane & $4.80 \mathrm{E}-03$ & 4.65E-02 & $2.42 \mathrm{E}-01$ & $2.59 \mathrm{E}-01$ \\
\hline $124-18-5$ & n-Decane & $5.90 \mathrm{E}-02$ & $7.00 \mathrm{E}-02$ & 3.64E-01 & $2.28 \mathrm{E}-01$ \\
\hline $142-82-5$ & n-Heptane & $2.00 \mathrm{E}-02$ & 2.35E-02 & $1.22 \mathrm{E}-01$ & $1.86 \mathrm{E}-01$ \\
\hline $111-84-2$ & n-Nonane & $1.20 \mathrm{E}-02$ & $6.50 \mathrm{E}-02$ & 3.38E-01 & $6.65 E-02$ \\
\hline $111-65-9$ & n-Octane & $2.90 \mathrm{E}-02$ & $3.80 \mathrm{E}-02$ & $1.98 \mathrm{E}-01$ & 3.33E-01 \\
\hline $109-66-0$ & n-Pentane & 3.30E-02 & $2.15 E-02$ & $1.12 \mathrm{E}-01$ & $4.55 \mathrm{E}-01$ \\
\hline $74-98-6$ & Propane & $1.60 \mathrm{E}-02$ & $2.25 \mathrm{E}-02$ & 1.17E-01 & $4.55 \mathrm{E}-01$ \\
\hline $624-64-6$ & trans-2-Butene & 2.40E-02 & $1.05 \mathrm{E}-01$ & $5.46 \mathrm{E}-01$ & 3.33E-01 \\
\hline $646-04-8$ & trans-2-Pentene & 4.60E-03 & 4.80E-03 & $2.50 \mathrm{E}-02$ & $1.75 \mathrm{E}-01$ \\
\hline
\end{tabular}

Source term estimation is a difficult process for any waste treatment facility because the exact identity of the particular wastes that will be treated cannot be predicted with absolute certainty. The use of emissions factors such as those presented in Bjorklund et al. (1998) enables health conservative factors to be identified and used to set an upper bound on the possible future conditions. Further benefits of using the Bjorklund et al. (1998) data are that the data are approved by the U.S. EPA and available to the public, making calculations easily reproducible and transparent.

\section{Exposure Assessment}

\section{Air Dispersion}

The release of constituents of concern from OB/OD operations is to air.

Generally, air dispersion modeling begins with (1) a stack height and (2) a plume rise associated with any momentum or temperature-induced flux that are added together and called the "effective release height." Because open burns and open detonations do not occur in buildings with stacks, the air dispersion models that are commonly used in risk assessment, such as Industrial Source Complex Short- 
Term (ISCST) model, are not applicable, unless appropriate adjustments are made. Moreover, most air dispersion models assume continuous releases, not short-term releases such as those associate with OB/OD treatments . However, the Open Burn Open Detonation Dispersion Model (OBODM, Bjorklund et al., 1998) was developed specifically for OB/OD operations. OBODM takes into account the short-term nature of $\mathrm{OB} / \mathrm{OD}$ treatments (i. e., quasi-continuous and instantaneous releases) and incorporates unique equations specifically developed to model the effective release height for burns and detonations. OBODM was used in this analysis to simulate the atmospheric release and dispersion of the constituents of concern from OB/OD operations at the EWTF.

OBODM allows the user to input various treatment-specific data, including mass of material treated, duration of treatment, and whether the treatment is a burn or detonation. OBODM allows the user to create a grid of receptors as well as up to 100 individual receptors not on the grid. It can be run in a mode that allows only one meteorological condition, or in a mode that allows many years of meteorological data to be taken into account. There are many output options available to the user; specific options used in this analysis are discussed below.

OBODM was used to model the four different waste forms/treatments at EWTF. Waste form 1 was modeled as an instantaneous open detonation. Waste forms 2, 3 , and 4 were modeled as quasi-continuous open burns. The source material modeled was TNT. TNT was chosen because it had the lowest heat release of the commonly treated munitions, which in turn lowers the plume rise and the dispersion, and increases the estimated concentrations to the downwind receptors.

OBODM models one source material and chemical of concern per model run. However, because resulting air concentrations scale linearly with input emission rates, the OBODM output can be scaled to estimate the concentrations of all chemicals of concern for all waste forms. This type of scaling is consistent with the HARP model (described below), which was used to calculate cancer risks, chronic hazards and acute hazards. Barium was chosen as the scaling chemical. It was modeled at two different emission factor levels: 0.0082 for Forms 1 and 2 treatments and 0.000086 for Forms 3 and 4 treatments. The OBODM outputs were then input to the HARP model for scaling (see Appendix A for a description of the scaling approach). OBODM and HARP input and output files are contained in the attached compact disk.

Four individual receptor locations were modeled (see discussion below), as well as locations necessary to complete the exposure pathways other than inhalation. Since the modeling region is located in complex terrain, the complex terrain option was employed and the receptor elevations were input to OBODM. The hours modeled were limited so that no operations would occur after 6:00 p.m. PST. No limitations on wind speed were incorporated into the modeling because OBODM warns that if such limitations were attempted the results may be invalidated. [The warning in the OBODM meteorological data limits menu states: "If any value in this menu is changed, program results may be invalid and 
cannot be supported by the authors of the OBODM program" (Bjorklund et al., 1998).]

Five years (2000-2004) of on-site hourly meteorological data were used in the modeling analysis. The Site 300 meteorological monitoring tower sensors record 15-minute average wind speed (from which average hourly wind speed is calculated), wind direction, sigma theta (standard deviation of the horizontal wind direction), temperature, delta temperature (delta- $T$ the difference in temperature between 2 and 10 meters), solar radiation and other parameters. The sensors meet or exceed the performance requirements found in the U.S. EPA document "Meteorological Monitoring Guidance for Regulatory Modeling Applications" (U.S. EPA, 2000). The tower's equipment undergoes annual audits and calibrations. Data completeness for each of the five years far exceeds 90 percent. Prior to December 2003, the atmospheric stability class was calculated using the sigma theta and mean wind speed method. After December 2003, the atmospheric stability class was calculated using the solar radiation/delta-T method. The meteorological data was put into OBODM (and ISCST) modelready format and a default mixing height of 600 meters was used. The meteorological datafile (Sit3y5.vec) is on the attached compact disk.

\section{Receptors}

Site 300 is located in a scarcely populated area, and only about 5 percent of the area is developed; see Figure 7. There are, however, two residences very near the southern boundary of the site; one is to the southeast of the Site 300 boundary, the other is near the middle of Site 300's southern boundary and is the residence of the park rangers for the Carnegie Vehicle Recreation Park. Both of the locations were evaluated to determine the location of maximum impact. Similarly, two locations for bystander workers (i.e., workers not conducting EWTF operations) were evaluated on site at Site 300. These locations are Building 812 Complex and Building 895. See Figure 8. 


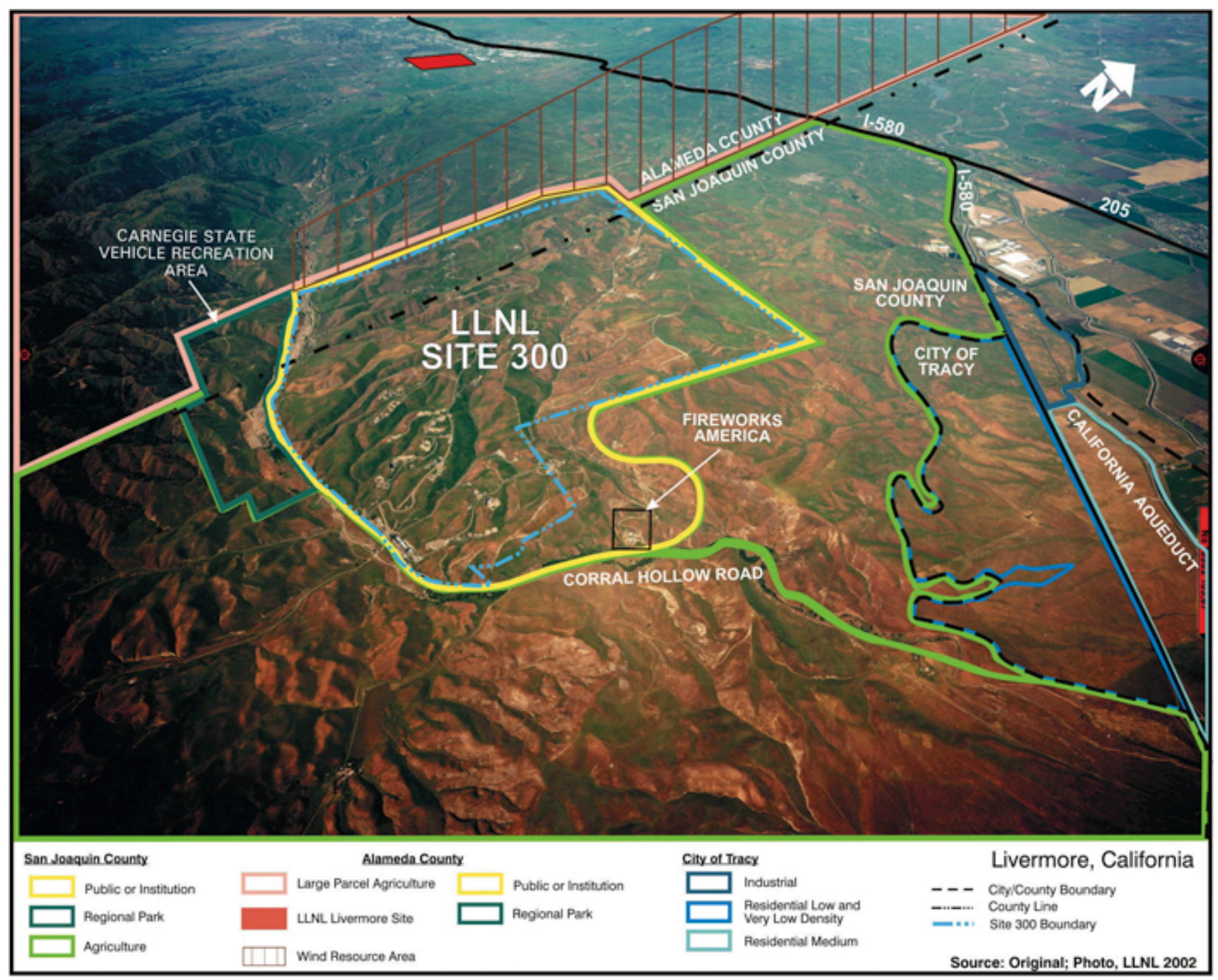

Figure 7. Site 300 environs.

Two types of offsite receptors are evaluated for carcinogenic risk: one is a child for the first 9 years of life, the other is a child/adult for a 30-year residence period. A 30-year residency is the 95th-percentile estimate of population mobility stated in the U.S. EPA Exposure Factors Handbook (U.S. EPA, 1997). The onsite bystander worker is evaluated for a 25-year work duration for carcinogenic risk, well above the U.S. EPA recommended occupational tenure value, which is a value of 6.6 years (U.S. EPA, 1997). For non-carcinogenic hazard, only adult 70year exposure was considered, as limited by the risk assessment tool (CARB, 2003). 


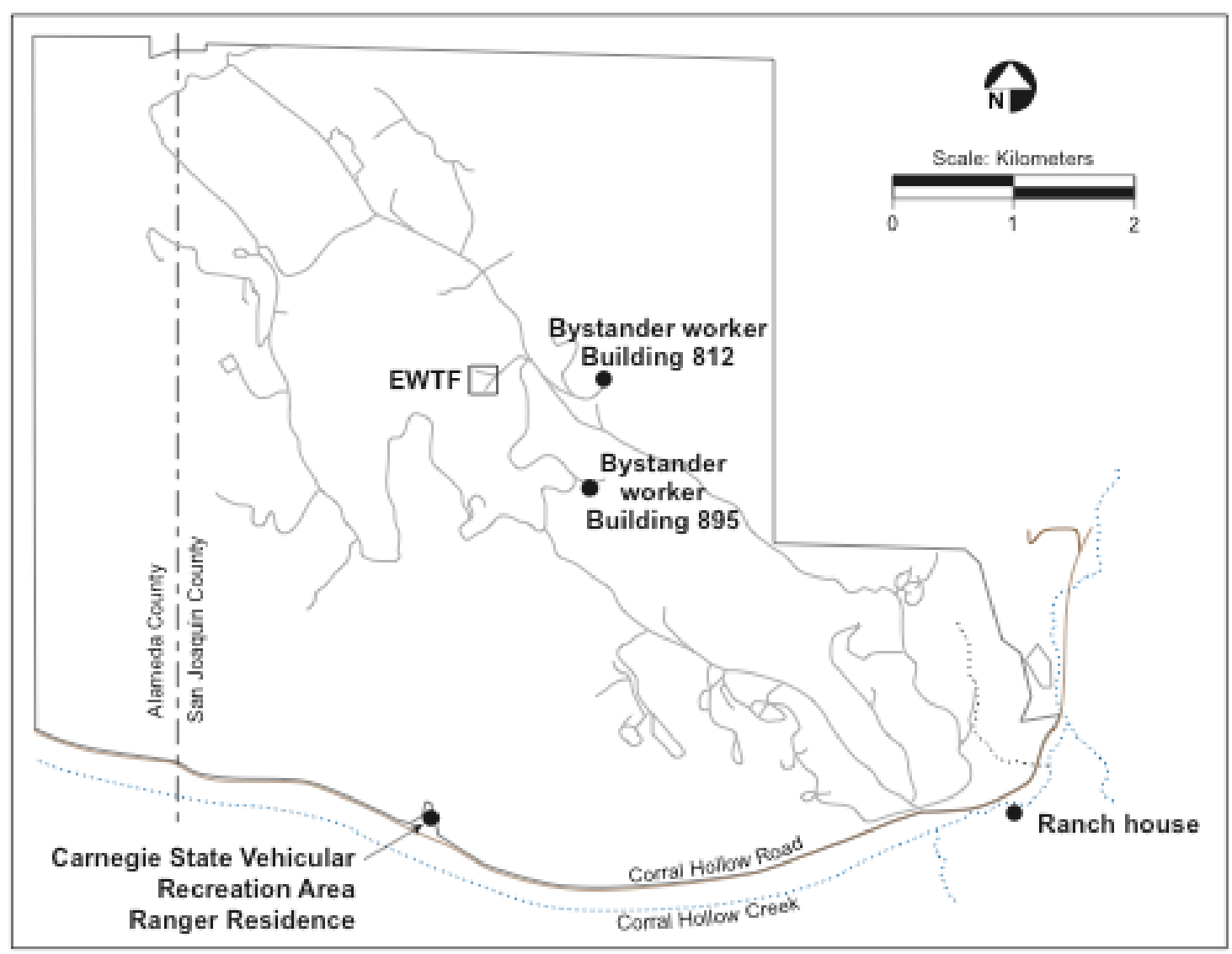

Figure 8. Locations of potentially maximally exposed receptors.

\section{Exposure Pathways}

Inhalation is the primary exposure pathway of concern for all receptors. The residential receptors also have the possibility of dermal exposure, of ingestion of home grown produce and meats, and incidental soil ingestion. Because dioxins and furans have been identified as constituents of concern, this assessment follows OEHHA guidance and evaluates the mother's milk exposure pathway (OEHHA, 2003, page 5-3).

OEHHA guidance on worker exposure is that those individuals have potential exposure due to incidental soil ingestion and dermal exposure. However, dermal exposure is an exposure pathway for which exposure factors have been developed for outside workers, such as construction workers, gardeners, and utility workers (U.S. EPA, 2004b p.3-15). Bystander worker areas identified for the EWTF are for inside workers. In view of the lack of exposure factor data available for indoor workers and the low probability of dermal exposure to soil of indoor workers, the dermal exposure pathway for bystander worker receptors is not calculated for this risk assessment. 
The HotSpots Analysis and Reporting Program (HARP; CARB, 2003) was used to calculate carcinogenic risk and acute and chronic non-carcinogenic hazard. The HARP model is a multi-pathway model and includes calculations for the inhalation pathway, ingestion pathway, dermal pathway and mother's milk pathway. The model contains default CARB/OEHHA recommended exposure parameters, which in some cases can be adjusted to better fit the factual situation. The exposure parameters used in this risk assessment and their regulatory sources are listed in Table 7. In addition, the HARP model offers a choice of analysis methods for carcinogenic risk including average and high-end point estimates and stochastic estimates. For this risk assessment, the high-end point estimate was used, and it is the high-end exposure parameters that are listed in Table 7.

Table 7. Exposure parameters used in EWTF risk assessment. Unless otherwise noted, all parameters are implemented in HARP (CARB, 2003) as described in OEHHA (2003) and represent high endpoints.

\begin{tabular}{|c|c|c|c|}
\hline Exposure Parameter & $\begin{array}{l}\text { Child (9-year } \\
\text { exposure) }\end{array}$ & $\begin{array}{l}\text { Adult resident (30- } \\
\text { year exposure) }\end{array}$ & $\begin{array}{l}\text { Adult worker (25- } \\
\text { year exposure) }\end{array}$ \\
\hline Body weight (kg) & 18 & 63 & 70 \\
\hline Exposure frequency $(\mathrm{d} / \mathrm{y})$ & 350 & 350 & 245 \\
\hline $\begin{array}{l}\text { Inhalation rate }[\mathrm{L} /(\mathrm{kg} \cdot \mathrm{d}) \text {; } \\
\text { 95th percentile] }\end{array}$ & 581 (10.46 $\mathrm{m}^{3} /$ day $)$ & 393 (24.76 m³/day) & 149 (10.4 m³/day) \\
\hline $\begin{array}{l}\text { Soil Loading }\left[\mathrm{mg} /\left(\mathrm{cm}^{2} \cdot \mathrm{d}\right) \text {; }\right. \\
\text { 95th percentile] }\end{array}$ & 1.0 & 1.0 & 1.0 \\
\hline $\begin{array}{l}\text { Exposed skin surface } \\
\text { area }\left(\mathrm{cm}^{2} ; \text { 95th }\right. \\
\text { percentile) }\end{array}$ & 3044 & 5500 & Not applicable \\
\hline $\begin{array}{l}\text { Soil Ingestion Rate } \\
{[\mathrm{mg} /(\mathrm{kg} \cdot \mathrm{d})]}\end{array}$ & $\begin{array}{l}8.7 \text { (corresponds to } \\
100 \mathrm{mg} / \text { day) }\end{array}$ & $\begin{array}{l}1.7 \text { (corresponds to } \\
100 \mathrm{mg} / \text { day) }\end{array}$ & $\begin{array}{l}0.7 \text { (U.S. EPA, } \\
1997 ; \text { corresponds } \\
\text { to } 50 \mathrm{mg} / \text { day) }\end{array}$ \\
\hline
\end{tabular}

HARP (CARB 2003) contains detailed calculations for the ingestion pathway, including the portions of the various types of foods ingested and the uptake of contaminants by agricultural animals. The user may adjust the home-produced fractions of the diet to reflect local conditions. The fractions that were changed and their default values are presented in Table 8. (It appears that some of the default factors were set at 1 , a common screening model representation of a hypothetical exposure; it is not likely that any individual in California is obtaining all of his beef, pork, chicken, dairy, and eggs from one location.) The fractions used in the assessment were all obtained from the U.S. EPA Exposure Factor Manual, Table 13-71, using the values stated for non-metropolitan areas. 
Table 8. Food consumption fraction estimated to be affected by EWTF.

\begin{tabular}{|l|c|c|}
\hline Food type & $\begin{array}{l}\text { Value used in risk } \\
\text { assessment (U.S. EPA, } \\
\text { 1997; Table 13-71, non- } \\
\text { metropolitan) }\end{array}$ & $\begin{array}{c}\text { HARP default value } \\
\text { (CARB, 2003) }\end{array}$ \\
\hline Exposed produce & 0.207 & 0.15 \\
Leafy produce & 0.082 (cabbage) & 0.15 \\
Protected produce & 0.134 & 0.15 \\
Root produce & 0.088 & 0.15 \\
Beef & 0.107 & 1.0 \\
Chicken & 0.026 & 1.0 \\
Pork & 0.04 & 1.0 \\
Dairy & 0 (Not applicable) & 1.0 \\
Eggs & 0.029 & 1.0 \\
\hline
\end{tabular}

The concentrations of contaminants of concern in the non-inhalation pathways are calculated in HARP based on a single deposition velocity for all contaminants of concern, and do not take into account particle size or mass. The default deposition velocity in HARP is $0.05 \mathrm{~m} / \mathrm{s}$ for uncontrolled sources. This value is extremely conservative. The authoritative review article on particle dry deposition by Sehmel (1980) indicates that only the largest particles would have such a deposition velocity. Moreover, particles with such a deposition velocity of $0.05 \mathrm{~m} / \mathrm{s}$ would in reality deposit very close to the source and would not deposit at the distances to residences of interest in this risk assessment. To be conservative, but realistic, a deposition velocity measured for dioxin was chosen to represent all contaminants of concern; this deposition velocity is $0.0072 \mathrm{~m} / \mathrm{s}$ (Wevers et al., 2004).

\section{Dose-Response Assessment}

The dose-response effects of chemicals in the environment are the subject of state and federal regulatory guidance. The cancer potency factors (CPFs), the acute and chronic inhalation reference exposure levels (RELs), and the chronic oral reference doses (RfDs) used in this assessment were compiled first from the OEHHA guidance as incorporated into the HARP model in the file called the health.mdb file, with a secondary source of such data obtained from the U.S. EPA Region 9 Preliminary Remediation Goal (PRG; U.S. EPA, 2004a) table, which lists the CPFs and RELs used in deriving the preliminary remediation goals. Table 9 presents the CPFs, RELs, and RfDs used in this risk assessment. 
Table 9. Cancer potency factors, relative exposure levels, and reference doses for chemicals of concern for the EWTF.

\begin{tabular}{|c|c|c|c|c|c|c|}
\hline $\begin{array}{l}\text { Material } \\
\text { CAS } \\
\text { Number }\end{array}$ & Material name & $\begin{array}{c}\text { Inhalation } \\
\text { cancer } \\
\text { slope } \\
\text { factor } \\
{[1 /(\mathrm{mg} / \mathrm{kg}-\mathrm{d})]}\end{array}$ & $\begin{array}{c}\text { Oral } \\
\text { cancer } \\
\text { slope } \\
\text { factor } \\
{[1 /(\mathrm{mg} / \mathrm{kg}-\mathrm{d})]}\end{array}$ & $\begin{array}{c}\text { Inhalation } \\
\text { chronic } \\
\text { REL } \\
(\mu \mathrm{g} / \mathrm{m} 3) \\
\end{array}$ & $\begin{array}{c}\text { Oral } \\
\text { chronic } \\
\text { RfD } \\
\text { (mg/kg-d) }\end{array}$ & $\begin{array}{c}\text { Acute } \\
\text { REL } \\
(\mu \mathrm{g} / \mathrm{m} 3)\end{array}$ \\
\hline $106-99-0$ & 1,3-Butadiene & $6.00 \mathrm{E}-01$ & & $2.00 \mathrm{E}+01$ & & \\
\hline 67562-39-4 & 1234678-HpCDF & $1.30 \mathrm{E}+03$ & $1.30 \mathrm{E}+03$ & $4.00 \mathrm{E}-03$ & $1.00 \mathrm{E}-06$ & \\
\hline 55673-89-7 & 1234789-HpCDF & $1.30 \mathrm{E}+03$ & $1.30 \mathrm{E}+03$ & 4.00E-03 & $1.00 \mathrm{E}-06$ & \\
\hline 70648-26-9 & 123478-HxCDF & $1.30 \mathrm{E}+04$ & $1.30 \mathrm{E}+04$ & 4.00E-04 & $1.00 \mathrm{E}-07$ & \\
\hline $57117-44-9$ & 123678-HxCDF & $1.30 \mathrm{E}+04$ & $1.30 \mathrm{E}+04$ & $4.00 \mathrm{E}-04$ & $1.00 \mathrm{E}-07$ & \\
\hline $35822-46-9$ & Total HpCDD & $1.30 \mathrm{E}+03$ & $1.30 \mathrm{E}+03$ & 4.00E-03 & $1.00 \mathrm{E}-06$ & \\
\hline $121-14-2$ & 2,4-Dinitrotoluene & $3.10 E-01$ & $6.10 E-01$ & $7.30 E+00$ & $2.00 E-03$ & \\
\hline $606-20-2$ & 2,6-Dinitrotoluene & $6.80 E-01$ & $6.80 E-01$ & $3.70 E+00$ & $1.00 E-03$ & \\
\hline $95-57-8$ & 2-Chlorophenol & & & $1.80 \mathrm{E}+01$ & $5.00 E-03$ & \\
\hline $107-05-1$ & Allyl Chloride & 2.10E-02 & & $1.00 \mathrm{E}+00$ & & \\
\hline $7429-90-5$ & Aluminum & & & $5.10 E+00$ & $1.00 E+00$ & \\
\hline $7440-36-0$ & Antimony & & & $2.00 \mathrm{E}-01$ & & \\
\hline $7440-39-3$ & Barium & & & $5.20 E-01$ & $7.00 E-02$ & \\
\hline $71-43-2$ & Benzene & $1.00 \mathrm{E}-01$ & & $6.00 \mathrm{E}+01$ & & $1.30 \mathrm{E}+03$ \\
\hline $7440-43-9$ & $\begin{array}{l}\text { Cadmium } \\
\text { Carbon }\end{array}$ & $1.50 \mathrm{E}+01$ & & $2.00 \mathrm{E}-02$ & 5.00E-04 & \\
\hline $56-23-5$ & Tetrachloride & $1.50 \mathrm{E}-01$ & & $4.00 \mathrm{E}+01$ & & $1.90 \mathrm{E}+03$ \\
\hline $67-66-3$ & Chloroform & 1.90E-02 & & $3.00 \mathrm{E}+02$ & & $1.50 \mathrm{E}+02$ \\
\hline $7440-47-3$ & Chromium & & & & $1.50 E+00$ & \\
\hline $7782-50-5$ & $\mathrm{Cl} 2$ & & & $2.00 \mathrm{E}-01$ & & $2.10 \mathrm{E}+02$ \\
\hline $630-08-0$ & $\mathrm{CO}$ & & & & & $2.30 \mathrm{E}+04$ \\
\hline $7440-50-8$ & Copper & & & $2.40 \mathrm{E}+00$ & $4.00 E-02$ & $1.00 \mathrm{E}+02$ \\
\hline $110-82-7$ & Cyclohexane & & & $6.20 E+03$ & $1.70 E+00$ & \\
\hline $84-66-2$ & Diethyl phthalate & & & $2.90 E+03$ & 8.00E-01 & \\
\hline $122-39-4$ & Diphenylamine & & & $9.10 E+01$ & $2.50 E-02$ & \\
\hline $75-00-3$ & Ethyl chloride & $2.90 E-03$ & & $3.00 E+04$ & & \\
\hline $100-41-4$ & Ethylbenzene & & & $2.00 \mathrm{E}+03$ & & \\
\hline $206-44-0$ & Fluoranthene & & & $1.50 E+02$ & $4.00 E-02$ & \\
\hline $7647-01-0$ & $\begin{array}{l}\text { HCL } \\
\text { i-Propylbenzene }\end{array}$ & & & $9.00 \mathrm{E}+00$ & & $2.10 \mathrm{E}+03$ \\
\hline $98-82-8$ & (cumene) & & & $4.00 E+02$ & $1.00 E-01$ & \\
\hline 7439-92-1 & $\begin{array}{l}\text { Lead } \\
\text { Methyl Chloride }\end{array}$ & 4.20E-02 & 8.50E-03 & & & \\
\hline $74-87-3$ & $\begin{array}{l}\text { (Chloromethane) } \\
\text { Methyl Chloroform }\end{array}$ & & & $4.50 E+01$ & & \\
\hline $71-55-6$ & $(1,1,1-\mathrm{TCA})$ & & & $1.00 \mathrm{E}+03$ & & $6.80 E+04$ \\
\hline $108-87-2$ & Methylcyclohexane & & & $3.10 E+03$ & & \\
\hline $75-09-2$ & Methylenechloride & $3.50 \mathrm{E}-03$ & & $4.00 \mathrm{E}+02$ & & $1.40 \mathrm{E}+04$ \\
\hline $91-20-3$ & Naphthalene & $1.20 \mathrm{E}-01$ & & $9.00 \mathrm{E}+00$ & & \\
\hline $110-54-3$ & $\begin{array}{l}\text { n-Hexane } \\
\text { Nitrogen Dioxide }\end{array}$ & & & $7.00 \mathrm{E}+03$ & & \\
\hline $10102-44-0$ & (peroxide) & & & $4.70 \mathrm{E}+02$ & & $4.70 \mathrm{E}+02$ \\
\hline $39001-02-0$ & OCDF & $1.30 \mathrm{E}+01$ & $1.30 \mathrm{E}+01$ & 4.00E-01 & $1.00 \mathrm{E}-04$ & \\
\hline $108-95-2$ & Phenol & & & $2.00 \mathrm{E}+02$ & $3.00 E-01$ & $5.80 E+03$ \\
\hline $115-07-1$ & Propene & & & $3.00 \mathrm{E}+03$ & & \\
\hline $121-82-4$ & RDX & $1.10 E-01$ & $1.10 E-01$ & $6.10 E-02$ & $3.00 E-03$ & \\
\hline
\end{tabular}




\begin{tabular}{|l|l|c|c|c|c|c|}
\hline $\begin{array}{l}\text { Material } \\
\text { CAS }\end{array}$ & $\begin{array}{c}\text { Inhalation } \\
\text { cancer } \\
\text { Number }\end{array}$ & $\begin{array}{c}\text { Slope } \\
\text { factor } \\
{[1 /(\mathbf{m g} / \mathbf{k g}-\mathrm{d})]}\end{array}$ & $\begin{array}{c}\text { Oral } \\
\text { cancer } \\
\text { slope } \\
\text { factor } \\
{[1 /(\mathbf{m g} / \mathbf{k g}-\mathrm{d})]}\end{array}$ & $\begin{array}{c}\text { Inhalation } \\
\text { chronic } \\
\mathbf{R E L} \\
(\boldsymbol{\mu g} / \mathbf{m} 3)\end{array}$ & $\begin{array}{c}\text { Oral } \\
\text { chronic } \\
\mathbf{R f D} \\
(\mathbf{m g} / \mathbf{k g}-\mathrm{d})\end{array}$ & $\begin{array}{c}\text { Acute } \\
\mathbf{R E L} \\
(\boldsymbol{\mu g} / \mathbf{m})\end{array}$ \\
\hline $100-42-5$ & Styrene & & $9.00 \mathrm{E}+02$ & & $2.10 \mathrm{E}+04$ \\
$7446-09-5$ & Sulfur Dioxide & & & $6.60 \mathrm{E}+02$ & & $6.60 \mathrm{E}+02$ \\
$127-18-4$ & Tetrachloroethylene & $2.10 \mathrm{E}-02$ & & $3.50 \mathrm{E}+01$ & & $2.00 \mathrm{E}+04$ \\
$108-88-3$ & Toluene & & & $3.00 \mathrm{E}+02$ & & $3.70 \mathrm{E}+04$ \\
$75-01-4$ & Vinyl Chloride & $2.70 \mathrm{E}-01$ & & $2.60 \mathrm{E}+01$ & & $1.80 \mathrm{E}+05$ \\
$7440-66-6$ & Zinc & & $3.50 \mathrm{E}+01$ & $5.00 \mathrm{E}-02$ & \\
\hline
\end{tabular}

Note: Toxicity factors in italics are from U.S. EPA (2004a) all others are from CARB (2003).

There were 27 constituents of concern for which no toxicity data were available in either the HARP model or in the U.S. EPA PRG table. Because of the uncertainty in the source term, it seemed reasonable to choose surrogates from the other constituents based on the fundamental structure of the molecule for which toxicity data were unavailable. On that basis, RDX was chosen as a surrogate for PETN; naphthalene was chosen as a surrogate for acenaphthalene and 1-nitronaphthalene; ethylbenzene was chosen as a surrogate for $\mathrm{m}$ - and -ethyltoluene; and hexane was chosen as a surrogate for short-chain and cyclic aliphatic hydrocarbons. A petroleum-industry toxicological review undertaken for the purpose of developing reference doses and reference concentrations evaluates materials by number of carbons in the compound and whether or not the material is aromatic or aliphatic (TPHCWG, 1997, p. 8). Consequently, hexane is a reasonable surrogate for these compounds.

\section{Risk Characterization}

\section{OBODM/HARP Interface}

As mentioned previously, OBODM is limited to the evaluation of one constituent of concern at a time. It also has no capability for assessing risk or hazard. On the other hand, HARP is capable of handling many chemicals simultaneously, and it incorporates the OEHHA methodology for assessing carcinogenic risk and noncarcinogenic hazard for the inhalation, food and incidental soil ingestion, dermal, and mother's milk exposure pathways. (In this risk assessment, HARPExpress, a commercial user interface to the HARP model was actually used.)

The HARP model is, in fact, three separate computer programs that are linked together. The first program is a database program where the user stores sitespecific data such as building locations, emissions locations, emissions characteristics (usually stack height, diameter, and release rate) and annual and maximum emissions. The second program is the ISCST model, a U.S. EPA continuous emission model for dispersion of air pollutants based on the Gaussian plume dispersion equations. The third program is the OEHHAapproved risk assessment equations combined with a database of OEHHAapproved toxicity factors, by which carcinogenic risk and acute and chronic noncarcinogenic hazard are calculated. 
As previously discussed, the ISCST model is not the most reasonable model to use for OB/OD operations; OBODM is the preferred model for these operations. However, because HARP is functionally three separate models that are linked together, it was possible to run both the HARP model and the OBODM model with the same emissions scenarios, and replace the ISCST output with OBODM output. The details of the HARP/OBODM interface are presented in Appendix A.

\section{Identification of Maximally Exposed Receptors}

Carcinogenic risk and acute and chronic non-carcinogenic hazard were calculated within HARP (with OBODM dispersion results) using OEHHAapproved equations. The calculations were conducted for the two possible residential receptors, and for the two closest locations of bystander workers. When the results for more than one receptor are provided by HARP, HARP output cannot be interrogated by source contribution. Because the contribution of each waste form was not known before the HARP model was run, for the screening purpose of identifying the maximally exposed receptors, all waste forms were modeled as if 100 events occurred annually. Therefore, the screening level health effects for identifying the maximally exposed receptors are for a total of 100 detonations and 300 burns (100 from each form of waste). These screening results yield greater health effects than would occur under the permit condition limits of no more than 100 detonations and 100 burns. (Historically, annual treatments are much less, both in frequency and mass, than the permitted limits.) The results of the HARP model screening runs are shown in Table 10. Output from the runs are provided on the attached $\mathrm{CD}$.)

Table 10. Screening results for identification of maximally exposed receptors.

\begin{tabular}{|l|c|c|c|}
\hline Receptor & $\begin{array}{c}\text { Carcinogenic } \\
\text { risk }\end{array}$ & $\begin{array}{c}\text { Chronic } \\
\text { hazard index }\end{array}$ & $\begin{array}{c}\text { Acute } \\
\text { hazard index }\end{array}$ \\
\hline Carnegie Ranger Station (SW) & 0.0000007 & 0.02 & 0.03 \\
Ranch Residence (SE) & 0.0000004 & 0.01 & 0.02 \\
Bystander Worker Building 812 (E) & 0.0000006 & 0.3 & 0.3 \\
Bystander Worker Building 895 (SE) & 0.0000007 & 0.3 & 0.3 \\
\hline
\end{tabular}

\section{Effects on Maximally Exposed Receptors}

After the maximally exposed receptors were identified, the HARP model was run again for the two individual receptors, the resident at the Carnegie State Vehicular Park ranger residence and the bystander worker at Building 895, to determine the contribution of each of the EWTF sources to the risk, and to determine the risk outcome for the permitted level of treatments of 100 open detonations and 100 open burns. The 100 burns were represented by the greatest value among the 3 waste forms that are treated by burning. Because acute hazard index is a measure of the greatest possible one-hour exposure, the result of interest is the highest one-hour hazard index for a single waste form, not the total 
of all waste forms. The results are presented in Table 11; the HARP output is contained in Volume 2 of this document.

In contrast to the 30-year exposure duration for the assessment of carcinogenic risk, the chronic hazard values are calculated for a 70-year exposure. This is because the HARP model uses chronic reference exposure limits (RELs) based on ambient air concentrations, rather than reference doses (RfDs), which are based on exposures, receptor body weight, and exposure duration. When an REL is developed, an exposure duration is assumed; in the case of the RELs used in HARP, the exposure duration is 70 years. This also means that a chronic hazard specific to childhood exposure cannot be calculated. In addition, the acute hazard calculation, while fundamentally the same for both worker and residential receptors, uses a greater inhalation rate for the worker than for the resident (1.3 $\mathrm{m}^{3} / \mathrm{h}$ for the worker and $1.0 \mathrm{~m}^{3} / \mathrm{h}$ for the resident). The result for the chronic hazard index reported by HARP is the maximum value among the target organs or systems evaluated. In all cases in this EWTF health evaluation, the maximally affected organ/system was the respiratory system.

Table 11. Health effects for maximally exposed receptors.

\begin{tabular}{|c|c|c|c|c|c|}
\hline Receptor & $\begin{array}{l}\text { Treatment unit (waste } \\
\text { form) }\end{array}$ & $\begin{array}{l}\text { Risk Adult } \\
\text { (30-year } \\
\text { exposure) } \\
\end{array}$ & $\begin{array}{l}\text { Risk Child } \\
\text { (9-year } \\
\text { exposure) } \\
\end{array}$ & $\begin{array}{l}\text { Chronic } \\
\text { hazard } \\
\text { index }\end{array}$ & $\begin{array}{l}\text { Acute } \\
\text { hazard } \\
\text { index }\end{array}$ \\
\hline \multirow[t]{6}{*}{$\begin{array}{l}\text { Carnegie ranger } \\
\text { residence (SW) }\end{array}$} & $\begin{array}{l}\text { Open Detonation } \\
\text { (Form 1) }\end{array}$ & 0.0000004 & 0.0000003 & 0.004 & 0.02 \\
\hline & Burn Pan (Form 2) & 0.00000004 & 0.00000002 & 0.01 & 0.01 \\
\hline & Burn Cage (Form 3) & 0.00000004 & 0.00000002 & 0.0008 & 0.0004 \\
\hline & Burn Cage (Form 4) & 0.0000002 & 0.0000001 & 0.004 & 0.002 \\
\hline & $\begin{array}{l}\text { Total (100 OD + } 300 \\
\text { OB) }\end{array}$ & 0.0000007 & 0.0000004 & 0.02 & $\begin{array}{l}\text { Maximum: } \\
0.02\end{array}$ \\
\hline & $\begin{array}{l}\text { Current permit limits } \\
(100 \mathrm{OD}+100 \mathrm{OB})\end{array}$ & 0.0000006 & 0.0000004 & 0.01 & $\begin{array}{l}\text { Maximum: } \\
0.02\end{array}$ \\
\hline \multirow{6}{*}{$\begin{array}{l}\text { Bystander } \\
\text { worker } \\
\text { (Building 895) }\end{array}$} & $\begin{array}{l}\text { Open Detonation } \\
\text { (Form 1) }\end{array}$ & 0.0000005 & $\begin{array}{l}\text { Not } \\
\text { applicable }\end{array}$ & 0.04 & 0.3 \\
\hline & Burn Pan (Form 2) & 0.0000001 & $\begin{array}{l}\text { Not } \\
\text { applicable }\end{array}$ & 0.2 & 0.2 \\
\hline & Burn Cage (Form 3) & 0.00000003 & $\begin{array}{l}\text { Not } \\
\text { applicable }\end{array}$ & 0.01 & 0.006 \\
\hline & Burn Cage (Form 4) & 0.0000001 & $\begin{array}{l}\text { Not } \\
\text { applicable }\end{array}$ & 0.05 & 0.03 \\
\hline & $\begin{array}{l}\text { Total ( } 100 \text { OD + } 300 \\
\text { OB) }\end{array}$ & 0.0000007 & & 0.3 & $\begin{array}{l}\text { Maximum: } \\
0.3\end{array}$ \\
\hline & $\begin{array}{l}\text { Current permit limits } \\
(100 \mathrm{OD}+100 \mathrm{OB})\end{array}$ & 0.0000006 & & 0.2 & $\begin{array}{l}\text { Maximum: } \\
0.3\end{array}$ \\
\hline
\end{tabular}




\section{Lead}

Possible emissions from OB / OD operations at the EWTF of Site 300 include elemental lead $(\mathrm{Pb})$. The chronic noncancer effects of lead exposure are related to blood lead levels (as opposed to ambient air concentrations). The health risk from exposure to lead in this risk assessment was determined using the lead risk assessment spreadsheet obtained from the Department of Toxic Substances Control (DTSC, 2000).

The DTSC Lead Risk Assessment Spreadsheet—LeadSpread 7 (DTSC, 2000)—is a model for estimating blood-lead concentrations resulting from exposure to lead via dietary intake, soil and dust ingestion, inhalation, and dermal contact. Because there are no actual or potential sources of drinking water at Site 300, exposure to lead in drinking water deposited as a result of $\mathrm{OB} / \mathrm{OD}$ emissions was not computed. The modeled concentrations of lead in air and soil 1-cm deep at the Carnegie State Vehicular Park ranger residence and at the bystander worker (Building 895) were used in the LeadSpread 7 calculations.

LeadSpread 7 contains equations that relate incremental blood lead increase to a concentration in an environmental medium, using currently accepted contact rates and empirically determined ratios. Exposure-pathway contributions to blood-lead levels are summed to arrive at an estimate of the median blood-lead concentration for multiple exposure pathways. The 99th-percentile concentration is then estimated from the median value by assuming a lognormal distribution for blood-lead concentration with a geometric standard deviation (GSD) of 1.6. The blood-lead concentration of concern for children and adults is $10 \_\mathrm{g} \mathrm{Pb} / \mathrm{dL}$, and risk management is considered applicable if there is a 0.01 risk of exceeding this value (DTSC, 1996).

Table 12 contains the values for the input factors required for performing the necessary calculations using LeadSpread 7 . The air and soil/ dust were obtained from OBODM/HARP atmospheric dispersion and deposition modeling (Bjorklund et al., 1998; CARB, 2003) and the percentage of homegrown produce consumed for the residence is the average of the data presented in Table 8. The default value for respirable dust that already is incorporated into LeadSpread 7 was not changed. Table 13 contains the 99th-percentile blood-lead levels predicted from lead emissions for adult and child exposures at the Ranger Location and for adult-worker exposures at the Building 895. None of the receptors, even the pica-child, is expected to achieve a blood-lead level that equals the $10 \_\mathrm{g} \mathrm{Pb} / \mathrm{dL}$ level at the 99th-percentile upper confidence limit. Consequently, no receptor is considered to attain a concentration of lead in blood that would be considered to be of concern. 
Table 12. Values for input factors required for the lead risk assessment spreadsheet model, LeadSpread 7.

\begin{tabular}{|l|l|l|}
\hline Environmental medium & Carnegie ranger residence & Bystander worker (Bldg. 895) \\
\hline Air & $0.00182 \mu \mathrm{g} \mathrm{Pb} / \mathrm{m}^{3}$ & $0.0286 \mu \mathrm{g} \mathrm{Pb} / \mathrm{m}^{3}$ \\
Soil/dust & $1.09 \mu \mathrm{g} \mathrm{Pb} / \mathrm{g}$ & $17.0 \mu \mathrm{g} \mathrm{Pb} / \mathrm{g}$ \\
Home-grown produce & $13 \%$ of diet & $0 \%$ of diet \\
Respirable dust & $1.5 \mu \mathrm{g} \mathrm{Pb} / \mathrm{m}^{3}$ & $1.5 \mu \mathrm{g} \mathrm{Pb} / \mathrm{m}^{3}$ \\
\hline
\end{tabular}

Table 13. Predicted blood-lead levels for adult and child exposures at the Ranger Location and for adult-worker exposures at the Building 895 location using the lead risk assessment spreadsheet model, LeadSpread 7.

\begin{tabular}{|l|c|c|c|c|}
\hline $\begin{array}{l}\text { Percentile } \\
\text { estimate of } \\
\text { blood lead } \\
\text { concentration }\end{array}$ & $\begin{array}{c}\text { Adult exposure } \\
\text { at Carnegie } \\
\text { ranger } \\
\text { residence } \\
(\mu \mathrm{g} / \mathrm{dL})\end{array}$ & $\begin{array}{c}\text { Child exposure } \\
\text { at Carnegie } \\
\text { ranger } \\
\text { residence } \\
(\mu \mathrm{g} / \mathrm{dL})\end{array}$ & $\begin{array}{c}\text { Pica-child } \\
\text { exposure at } \\
\text { Carnegie ranger } \\
\text { residence } \\
(\mu \mathrm{g} / \mathrm{dL})\end{array}$ & $\begin{array}{c}\text { Bystander } \\
\text { worker } \\
\text { exposure at } \\
\text { Building 895 } \\
(\mu \mathrm{g} / \mathrm{dL})\end{array}$ \\
\hline 99 th & 0.6 & 1.5 & 1.5 & 0.8 \\
\hline
\end{tabular}




\section{Ecological Risk Assessment}

The Ecological Risk Assessment (ERA) for the EWTF was conducted following currently accepted practice. This practice involves the following four steps. The first step is to identify each contaminant of potential ecological concern (CPEC) in emissions from OB/OD operations that also has a toxic reference value (TRV) available in the literature. In the second step, the concentrations of CPECs deposited in the habitat, as determined by atmospheric dispersion and deposition modeling, are used in an exposure-pathway analysis for each representative receptor of ecological interest (RREI). The third step is to sum the exposure-pathway doses from a contaminant for a receptor to obtain a total dose for that receptor from that contaminant. The fourth step is the calculation of an "ecologocial hazard quotient," i.e., the ratio of total daily dose to the toxic reference value (TRV) for each contaminant of potential concern and each receptor species as a quantitative metric for evaluating whether there is any significant potential for adverse effects on RREI populations in the habitat near the EWTF.

The CPECs in emissions from the EWTF for which sufficient data were available in the literature to conduct an ecological risk assessment are the heavy metals cadmium $(\mathrm{Cd})$, copper $(\mathrm{Cu})$, lead $(\mathrm{Pb})$, and zinc $(\mathrm{Zn})$ and six specific congeners of polychlorinated dibenzo-p-dioxins and dibenzofurans (PCDDs/PCDFs). The RREIs to be addressed are the California Ground Squirrel (Spermophilus beecheyi), San Joaquin Kit Fox (Vulpes macrotis mutica), and Burrowing Owl (Athene cunicularia), and the Black-tailed Deer (Odocoileus hemionus columbianus).

The individual exposure pathways considered relevant for each RREI are inhalation of contaminated soil particulates resuspended into air; incidental ingestion of contaminated soil particles; and ingestion of forage or prey for which uptake of a CPEC from soil is estimated using a calculated uptake factor. The intake of contaminated water by an RREI is not addressed in this ERA because there are no significant surface or ground waters in the habitat at the location of maximum exposure. Additionally, for purposes of conservatism, all RREI living, foraging, and prey capturing is considered to occur in the habitat nearest OB/OD operations, where highest concentrations of each CPEC are predicted to be deposited, and the absorption fraction of each CPEC from the lungs and intestinal tract of each RREI is considered to be 100 percent.

The California Ground Squirrel, San Joaquin Kit Fox, and Burrowing Owl, are all fossorial (i.e., burrowing), and the Black-tailed Deer is nonfossorial. Additionally, the San Joaquin Kit Fox and Burrowing Owl are considered to represent a different level of the food chain than either the squirrel or the Blacktailed Deer. The prey of the Kit Fox and the Burrowing Owl is represented by the squirrel and is considered to be the entire diet for the Kit Fox (based on information used by Carlsen, 1996) and 50\% of the diet for the Burrowing Owl (based on information noted by Biermann et al., 2001). The Black-tailed Deer, like the squirrel, is considered to be herbivorous (based on information used by Carlsen, 1996). 
The technical basis for this ecological risk assessment is a quantitative analysis that includes all relevant exposure pathways for each CPEC with respect to its ecological hazard quotient for a particular receptor. An ecological hazard quotient with a value greater than or equal to 1.0 suggests a potential for producing an adverse effect in each individual or population of receptor species. Appendix B contains a detailed description of the ERA analysis and input data.

The results of the ecological risk assessment are summarized in Table 14. No representative receptor of ecological interest is predicted to have an ecological hazard quotient greater than or equal to one for any contaminant of potential ecological concern, and this is true whether low toxic reference values $\left(T_{R V_{\text {Low }}}\right)$ or high toxic reference values $\left(\mathrm{TRV}_{\mathrm{High}}\right)$ are used as the denominator for the ecological hazard quotient calculation. The $\mathrm{TRV}_{\text {Low }}$ is considered to represent a credible lowest no adverse effect level, and the $\mathrm{TRV}_{\mathrm{High}}$ is considered to represent the mid-point of the threshold for a variety of adverse effects (DTSC, 2002a,b).

Because of the conservatisms used in computing the ecological hazard quotient values, and the fact that the computed ecological hazard quotient is a value less than one, it is reasonable to conclude that a condition of de minimis ecological risk is likely for an individual or population of receptors of ecological interest near the EWTF as a result of exposures to any contaminant of potential ecological concern.

Table 14. Ecological hazard quotients (i.e., ratio of total dose to respective bodyweight-scaled TRV) for each representative receptor of interest and contaminant of potential ecological concern.

\begin{tabular}{|c|c|c|c|c|c|c|c|c|}
\hline \multirow{2}{*}{$\begin{array}{l}\text { Chemicals } \\
\text { of potential } \\
\text { ecological } \\
\text { concern } \\
\text { (CPEC) }\end{array}$} & \multicolumn{2}{|c|}{$\begin{array}{c}\text { California Ground } \\
\text { Squirrel }\end{array}$} & \multicolumn{2}{|c|}{$\begin{array}{l}\text { Black-tailed } \\
\text { Deer }\end{array}$} & \multicolumn{2}{|c|}{$\begin{array}{l}\text { San Joaquin } \\
\text { Kit Fox }\end{array}$} & \multicolumn{2}{|c|}{$\begin{array}{l}\text { Burrowing } \\
\text { Owl }\end{array}$} \\
\hline & $E H Q_{\text {Low }}$ & $E H Q_{\text {High }}$ & $E H Q_{\text {Low }}$ & $E H Q_{\text {High }}$ & $E H Q_{\text {Low }}$ & $E H Q_{\text {High }}$ & $E H Q_{\text {Low }}$ & $E H Q_{\text {High }}$ \\
\hline $\begin{array}{l}\text { Cadmium } \\
\text { (Cd) }\end{array}$ & 0.19 & 0.0044 & 0.84 & 0.019 & 0.82 & 0.019 & 0.092 & 0.00071 \\
\hline $\begin{array}{l}\text { Copper } \\
\text { (Cu) }\end{array}$ & 0.15 & 0.00065 & 0.037 & 0.00016 & 0.21 & 0.00088 & 0.46 & 0.020 \\
\hline Lead $(\mathrm{Pb})$ & 0.0015 & 0.0000074 & 0.00054 & 0.0000026 & 0.011 & 0.000053 & 0.75 & 0.0019 \\
\hline Zinc (Zn) & 0.040 & 0.00080 & 0.016 & 0.00038 & 0.37 & 0.0086 & 0.25 & 0.025 \\
\hline $\begin{array}{l}\text { PCDDs/ } \\
\text { PCDFs }\end{array}$ & 0.0018 & $\begin{array}{l}\text { None } \\
\text { available }\end{array}$ & 0.0015 & $\begin{array}{l}\text { None } \\
\text { available }\end{array}$ & 0.0097 & $\begin{array}{l}\text { None } \\
\text { available }\end{array}$ & 0.00059 & $\begin{array}{l}\text { None } \\
\text { available }\end{array}$ \\
\hline
\end{tabular}

Note: The toxic reference values (TRVs) for PCDDs/PCDFs were obtained from an ecological risk assessment prepared for Toronto (Canada) Public Health by Jacques Whitford Limited (2004) and are considered representative of $\operatorname{TRV}_{\text {Low }} \mathrm{s}$. All other TRV values were obtained from DTSC $(2002 a, b)$. In calculating EHQs, a scaling factor based on body weight was applied to convert the TRV obtained from the literature for an experimental test species to a TRV that is considered more directly applicable to the representative receptor of ecological interest. 


\section{Uncertainties and Conservatisms}

Quantification of health risk from the operation of the EWTF involves estimating the magnitude of emissions, the concentrations of the constituents of concern in various environmental media, and the magnitude of exposure as well as exposure frequency and duration for exposure pathways of concern for specific receptors. This risk assessment has implemented 95th-percentile estimates, when possible, and health-conservative estimates, when the distribution of the parameter is unknown, for the parameters that could be controlled within the models used.

Quantification of the source term for the EWTF is uncertain: it is difficult to predict the exact nature of the explosives that will be treated. This uncertainty has been addressed by using the most conservative emissions factors that can be reasonably justified. The continued research conducted by the Department of Defense in this area will improve emission factors for future permitting efforts and reduce the uncertainty from the emission factor, but the inherent uncertainty in exactly predicting releases from waste treatment operations at a research institution will remain.

Quantification of the air concentrations is uncertain. This uncertainty has been addressed by using the most health conservative munition, TNT, in the OBODM model. TNT is the most health conservative because it has the lowest heat of combustion, leading to the least plume rise, and, therefore, the greatest downwind concentrations. The uncertainty in the prediction of air concentrations is reduced by the use of five years of site-specific meteorological data in the air dispersion modeling.

Quantification of the soil concentrations is uncertain. This uncertainty was addressed by using a deposition velocity for the constituents of greatest health concern, polychlorinated dibenzodioxins and polychlorinated dibenzofurans.

There are uncertainties as to the magnitude of exposure. These uncertainties have been addressed through the use of 95th-percentile inhalation rates for residential receptors and bystander workers, for the incidental soil ingestion rate for residential receptors, for the skin surface area and dermal adhesion factor for the dermal exposure route for residential receptors. The dermal exposure route is uncertain for the indoor receptors in that there are no recommended exposure factors for this route/receptor combination; however, it is unlikely that any indoor worker would have a significant soil dermal exposure.

The 30-year residency exposure assumption is the 95th-percentile estimate of population mobility stated in the U.S. EPA Exposure Factors Handbook (U.S. EPA, 1997). The average residence in one place is estimated to be significantly less, at 11.4 years for homeowners and 2.4 years for renters (Israeli and Nelson, 1992). The onsite bystander worker is evaluated for a 25-year work duration, well above the U.S. EPA recommended occupational tenure value of 6.6 years (U.S. EPA, 1997). It should also be noted that HARP does not have distinct point estimates and data distributions for the 30 year and 70 year exposure scenarios. The documentation 
states: "However, in the interest of simplicity, the 30-year exposure duration scenario uses the same exposure point-estimates and data distributions as the 70year exposure duration scenario. This assumption to use the 70-year exposure point-estimate for both 30 and 70-year exposures probably results in a small underestimation of dose for the 30-year exposure scenario, since the exposure parameters for earlier years are higher than years spent as an adult" (OEHHA, 2003).

Quantification of toxic effects involves applying appropriate toxicity data to the constituents of potential concern. However, not all constituents of concern for the EWTF have toxicity data. This uncertainty was addressed by identifying surrogate materials and using the toxicity data for the surrogate material to estimate risk and hazard.

Studies of the compounding of conservatism in probabilistic risk assessments show that setting as few as two factors at high end levels (e.g., near the 90th percentile), while the remaining variables are set at less conservative, or expected values results in a product of all input variables that approximate a maximum exposure value (e.g., 99th-percentile value) (Cullen, 1994). This risk assessment uses 95th-percentile estimates for inhalation rates, residential ingestion rates, and skin surface exposure. As a result it provides a very conservative estimate of health effects that are, nonetheless, below any level of concern.

Quantification of the ecological risk posed by release of a particular contaminant to a specific habitat is complicated by additional uncertainties related to limited data concerning the physiological and behavioral characteristics of those wildlife species that are considered to be present. To overcome such difficulties, quantitative ecological risk assessment, as currently practiced, focuses on modeling potential total dose and developing an ecological hazard quotient for an individual organism of one or more species (and most often only for adults due to data limitations) in the affected habitat, so that any impact to an individual of a particular species may translate to an impact to the population, and by inference, to a potential impact on the entire local ecosystem. Following this approach, this ecological risk assessment examines the potential for impact from a contaminant of potential ecological concern for an individual receptor from more than one species, with each species considered to be at a different trophic level in the local ecosystem near the EWTF. Additional conservatism is added to these calculations by maximizing the amount of material deposited (by considering a habitat location at Site 300 quite close to the OB/OD operations-the source of emissions); optimizing the receptor behavior to maximize exposures (i.e., living, foraging, and capturing prey exclusively in that immediate habitat); and fixing the absorption fraction of each contaminant in the lungs and intestinal tract of each receptor at 100 percent. Adding these conservatisms acts to address uncertainty because they increase the likelihood that each calculated ecological hazard quotient will be an overestimate. Because none of the resulting values for ecological hazard quotient (i.e., $\mathrm{EHQ}_{\mathrm{Low}}$ ) in this ERA are greater than or equal to one, having also added conservatisms to the inputs, it is therefore expected that OB /OD operations at Site 300 are unlikely to produce or contribute significantly to any ecological impacts. 


\section{Summary of Risks and Hazards}

The calculations evaluating human health risk in this assessment are based on health conservative assumptions for nearly every parameter, which yields a very conservative upper bound estimate of potential health effects. The calculations demonstrate that the operations at the EWTF do not constitute a human health risk: the carcinogenic risk is less than one in one million, and the acute and chronic hazard indices are less than 1 . In addition, the assessment of the lead noncarcinogenic hazard is well below a blood-lead level of $10 \_\mathrm{g} \mathrm{Pb} / \mathrm{dL}$. Moreover, the ecological hazard quotients are calculated to be less than one. Therefore, it is unlikely that EWTF operation will produce any significant human health or ecological impacts. 


\section{References}

Biermann, A., P. Althouse, N. Bertoldo, R. Blake, S. Brigdon, R. Brown, C. Campbell, E. Christofferson, L. Clark, K. Folks, G. Gallegos, A. Grayson, R. Harrach, J. Larson, D. MacQueen, S. Mathews, B. Nisbet, S. Peterson, M. Taffet, P. Tate, R. Vellinger, and R. Williams (2001), Environmental Report for 2000, Lawrence Livermore National Laboratory, Livermore, CA (UCRL-50027-00).

Bjorklund, J. R., J. F. Bowers, G. C. Dodd, and J. M. White (1998), Open Burn/Open Detonation Dispersion Model (OBODM) User's Guide, West Desert Test Center, Dugway Proving Ground, Dugway, UT (DPG Document No. DPG-TR-96-008a) (http: / / www.epa.gov/scram001/tt22.htm ).

California Environmental Protection Agency, Air Resources Board (CARB) (2003), HotSpots Analysis and Reporting Program User Guide, Developed by Dillingham Software Engineering, Inc., Air Resources Board, Stationary Source Division, Sacramento, California.

Carlsen, T.M. (1996), "Ecological Risks to Fossorial Vertebrates from Volatile Organic Compounds in Soil," Risk Analysis 16(2), 211-219.

Cullen, A. C., "Measures of Compounding Conservatism in Probabilistic Risk Assessment," Risk Analysis, 14(4):389-393 (1994).

Department of Toxic Substances Control (DTSC) (1996), "Chapter 7: Assignment of Health Risks from Inorganic Lead in Soil," in Supplemental Guidance for Human Health Multimedia Risk Assessments of Hazardous Waste Sites and Permitted Facilities, State of California Environmental Protection Agency, Office of Scientific Affairs, Department of Toxic Substances Control, Sacramento, CA, OSA Guidance (July 1992/ corrected and reprinted August 1996).

Department of Toxic Substances Control (DTSC) (2000), LeadSpread 7: DTSC Lead Risk Assessment Spreadsheet, State of California Environmental Protection Agency, Department of Toxic Substances Control, Sacramento, CA

(http://165.235.111.242/ AssessingRisk/leadspread.cfm)

Department of Toxic Substances Control (DTSC) (2002a), Revised U.S. Environmental Protection Agency (USEPA) Region 9 Biological Technical Assistance Group (BTAG) Mammalian Toxicity Reference Value (TRV) for Lead: Justification and Rationale, State of California Environmental Protection Agency (Cal/EPA), Department of Toxic Substances Control (DTSC), Sacramento, CA, Human and Ecological Risk Division (HERD) Ecological Risk Assessment (ERA) Note Number 5 (EcoNote5), November 21, 2002 (http://165.235.111.242/AssessingRisk/eco.cfm\#EcoNOTE5). 
Department of Toxic Substances Control (DTSC) (2002b), Currently Recommended U.S. Environmental Protection Agency Region 9 Biological Technical Assistance Group (BTAG) Mammalian and Avian Toxicity Reference Values (TRVs), State of California Environmental Protection Agency (Cal/EPA), Department of Toxic Substances Control (DTSC), Sacramento, CA, November 21, 2002 ; two data tables and accompanying references (http:/ / 165.235.111.242/AssessingRisk/eco.cfm\#EcoNOTE5).

Israeli, M., and C. B. Nelson (1992), "Distribution and Expected Time of Residence for U.S. Households," Risk Analysis 12, 65-72.

Mitchell, W.J., and J.C. Suggs (1998), Emission Factors for the Disposal of Energetic Materials by Open Burning and Open Detonation (OB/OD), U.S. Environmental Protection Agency, MD-46, Research Triangle Park, NC 27711, (EPA/600/R-98103).

Mitchell, W.J. (1999), State of the Science and Research Needs in the Characterization and Minimization of the Emissions from Ordnance Use and Disposal Activities, Strategic Environmental Research and Development Workshop, June 2-4, 1999, co-sponsored by American Academy of Environmental Engineers, http://www.aaee.net/newlook/air quality issues.htm .

National Academy of Sciences (NAS) (1983), Risk Assessment in the Federal Government. Managing the Process. National Academy Press, Washington, DC.

Office of Environmental Health Hazard Assessment (OEHHA) (2003), Air Toxics Hot Spots Program Risk Assessment Guidelines The Air Toxics Hot Spots Program Guidance Manual for Preparation of Health Risk Assessments, Office of Environmental Health Hazard Assessment, California Environmental Protection Agency, Oakland, California.

Sehmel, G., (1980), "Particle and Gas Dry Deposition: A Review," Atmospheric Environment 14, 983-1011.

Total Petroleum Hydrocarbon Criteria Working Group (TPHCWG) (1997), Development of Fraction Specific Reference Doses (RfDs) and Reference Concentrations (RfCs) for Total Petroleum Hydrocarbons (TPH), Prepared by Exxon Biomedical Sciences, Inc.: D.A. Edwards, M.D. Andriot, M.A. Amoruso, A.C. Tummey, C.J. Bevan, A. Tveit, L.A. Hayes; EA Engineering, Science, and Technology, Inc.: S.H. Youngren; Remediation Technologies, Inc.: D.V. Nakles, Amherst Scientific Publishers, Amherst, Massachusetts.

United States Environmental Protection Agency (U.S. EPA) (1997), Exposure Factors Handbook, United States Environmental Protection Agency, Office of Research and Development, National Center for Environmental Assessment, Washington, DC (EPA/600/ P-95/002Fa, August 1997). 
United States Environmental Protection Agency (U.S. EPA) (2000), Meteorological Monitoring Guidance for Regulatory Modeling Applications, Office of Air Quality Planning and Standards, Research Triangle Park, NC (EPA-454/R-99-005).

United States Environmental Protection Agency (U.S. EPA) (2004a), Region 9 Preliminary Remediation Goal Table (U.S. Environmental Protection Agency, Region 9, San Francisco, CA, October 2004), http:/ / www.epa.gov/ region09/ waste/sfund/prg/.

United States Environmental Protection Agency (U.S. EPA) (2004b), Risk Assessment Guidance for Superfund Volume I: Human Health Evaluation Manual (Part E, Supplemental Guidance for Dermal Risk Assessment,) Office of Superfund Remediation and Technology Innovation U.S. Environmental Protection Agency Washington, DC, (EPA/540/R/99/005 OSWER 9285.7-02EP PB99-963312).

Wevers, M., R. DeFré, M. Desmedt (2004), "Effect of backyard burning on dioxin deposition and air concentrations," Chemosphere 54, 1351-1356. 


\section{Appendix A. Integration of OBODM into HARP}

As stated in the main body of this risk assessment, the standard approach for human health risk assessment is a four-step process stated by the National Academy of Sciences in Risk Assessment in the Federal Government: Managing the Process (NAS, 1983) and reiterated in The Air Toxics Hot Spots Program Guidance Manual for Preparation of Health Risk Assessments (OEHHA, 2003). The four steps in the process are (1) hazard identification, (2) exposure assessment, (3) doseresponse assessment, and (4) risk characterization.

For this risk assessment for the EWTF, DTSC recommended the use of the Open Burn Open Detonation Dispersion Model [OBODM; Bjorklund et al., 1998. Region III of the U.S. EPA (2002) also recommends its use]. OBODM has components that allow completion of steps 1 and 2, i.e., it contains emissions factors for many chemicals based on tests of 39 types of munitions (see also Mitchell and Suggs, 1998) and it contains a Gaussian-plume air dispersion model developed specifically for short-term episodic releases, such as open burns and open detonations. OBODM emission factors have been widely used to estimate the hazards from $\mathrm{OB} / \mathrm{OD}$ and similar operations. ${ }^{3}$ It is more common for a risk assessor to identify the hazards through developing source-specific information and / or through the use of approved emissions factors not specifically included in the air dispersion model. Unfortunately, OBODM only allows the estimation of one released chemical for each treated material for each model run. That is, if an $\mathrm{OB} / \mathrm{OD}$ treatment involved the release of 10 materials, OBODM would have to be run 10 times, or, because the model is linear with respect to the initial released chemical, OBODM could be run once and a scaling factor then used to scale the result up or down depending on the ratio of the initial chemical to the chemical in question. (For example, if chemical A has an emission factor of 1 and chemical $\mathrm{B}$ has an emission factor of 2, OBODM could be run for chemical $\mathrm{A}$, and the air concentrations would be used without adjustment for chemical A and would be multiplied by 2 for chemical B.)

To complete this risk assessment, the Hotspot Analysis Reporting Program (HARP) (CARB, 2003) was used. This model was developed by OEHHA and the California Air Resources Board for compliance with the AB2588 Hotspots

\footnotetext{
${ }^{3}$ For example, OBODM emission factors have been used by the U.S. Navy and affirmed by the Agency for Toxic Substances Disease Registry (ATSDR) in evaluating emissions from Isla de Vieques, Puerto Rico, bombing range: (http:/ / www.atsdr.cdc.gov/HAC/PHA/vieques4/vbr p5.html): "The Navy contractor used emission factors derived from Bangbox studies to estimate emissions of chemical by-products of bombing activities. These emission factors have been widely used to assess environmental impacts from open burning and open detonation activities. For instance, the Open Burn/Open Detonation Model (OBODM), available from EPA's clearinghouse of dispersion models on the agency's technology transfer network, also estimates air emissions from the Bangbox emission factors. ATSDR acknowledges that the representativeness of static detonation tests to live bombing exercises has not been established. However, source testing (or emissions measurements) during live bombing exercises is an extremely complicated endeavor, given the potential safety hazards associated with placing field surveying equipment in the proximity of bombing targets. In the absence of such source testing results, ATSDR believes the Bangbox emission factors are reasonable indicators of chemical releases from explosions."
} 
reporting requirements. HARP provides assistance with steps 2, 3 and 4 of risk assessment: (2) exposure assessment, (3) dose-response assessment, and (4) risk characterization. The HARP model is available in two formats: a free selfcontained version, and a commercial version (called HARPExpress) that relies on Microsoft Excel to provide a user-friendly interface for putting information into the program. In this risk assessment, although HARPExpress was used, the model is referred to as "HARP."

To accomplish the exposure assessment portion of the risk assessment, HARP incorporates the Industrial Source Code, Short Term (ISCST) model. ISCST is the U.S. EPA regulatory model most commonly used in permitting actions; it includes the common assumptions that emissions are continuous and that they are vented through a stack. Consequently, the air dispersion modeling output of HARP could not be used (at least without some manipulation). However, HARP is quite robust in its treatment of dose-response assessment and risk characterization. It allows modeling of many chemicals at the same time (in this case 51), and is limited only by the availability of toxicological information. It is the model of general application to air emissions that has been developed by the California Air Resources Board for compliance with the Air Toxic Hot Spots regulations.

The problem that arose in this risk assessment was to determine how to integrate the source term and atmospheric modeling capabilities of OBODM together with exposure assessment, dose response and risk characterization attributes of HARP.

The integration of the emissions factors information was straightforward. The emissions factors from OBODM were read into a Microsoft Access database file. The database file was queried for the munitions that were identified as those representative of waste Forms 1 through 4 and the highest emission factor for each emitted chemical was selected. These emissions factors were multiplied by the amount of material treated, and the emissions estimates for each chemical for each waste form were copied into HARP.

The integration of the air dispersion modeling was somewhat more complex. First, it is important to remember that HARP is written in a modular form, and that the modules operate independently. The HARP modules are the source term calculations, the air dispersion calculations (which is the ISCST model), and the risk and hazard calculations. Only the air dispersion modeling of HARP needed to be changed from ISCST output to OBODM output.

Fortunately (from the point of view of inserting OBODM results into HARP), ISCST (within HARP) begins all of its air dispersion calculations from the assumption that 1 gram per second $(1 \mathrm{~g} / \mathrm{s})$ is being released from a facility; it does not use the actual emissions until later in the modeling code. From the starting point of a $1 \mathrm{~g} / \mathrm{s}$ release (also called a unit-source release), ISCST then calculates the concentrations at all the receptor locations identified in the input file, in micrograms per cubic meter of air $\left(\mu \mathrm{g} / \mathrm{m}^{3}\right)$ for that $1 \mathrm{~g} / \mathrm{s}$ release. The 
result is called the unit source " $\mathrm{X} / \mathrm{Q}$," where " $\mathrm{X}$ " (the Greek letter "chi") is the concentration at the receptor location and " $\mathrm{Q}$ " is the emission rate for the material of interest. The X/Q data are located in an ISCST file named "filename.XOQ", where "filename" represents the file name of the particular model run.

Therefore, to incorporate OBODM results into HARP, the modeler needs to acquire a unit source " $\mathrm{X} / \mathrm{Q}$ " from the OBODM model for all receptor locations and substitute that data into the "filename.XOQ" file. After the substitution is made, the risk and hazard assessments modules of HARP can be run based on OBODM X/Q data. OBODM does not have an intermediate " $\mathrm{X} / \mathrm{Q}$ " file that is obviously accessible. However, the OBODM primary output, ground level concentrations, can be used with the input emissions concentrations to calculate the $\mathrm{X} / \mathrm{Q}$ for each location. This was the approach that was taken. It was used for both maximum hourly $\mathrm{X} / \mathrm{Q}$ and annual average $\mathrm{X} / \mathrm{Q}$.

The chemical barium was selected for the calculation because it had an emission factor for all four waste forms. The emission factor for barium for Forms 1 and 2 was 0.0082 , and the emission factor for Forms 3 and 4 was 0.000086. The OBODM model was run for each of these emission factors for all four forms. Because a "unit" X/Q was being calculated, the results should be the same without regard to the initial emission factor. The use of actual emission factors enabled checking the concentration of barium for each of the waste forms in HARP after the substitution was made.

To reiterate, the concentration output of the OBODM model must be divided by the emission rate for each of the waste forms to yield a unit source $X / Q$. However, this step requires the availability of the source emission rates. These emission rates were calculated from the estimated masses of the quantities emitted per second; the calculations and the resulting emission rates are shown in Table A-1. Table A-2 shows the unit source X/Q calculations based on the 0.0082 barium emission factor and Table A-3 shows the unit source X/Q calculations based on the 0.000086 barium emission factor. Comparison of Tables A-2 and A-3 shows that the unit source X/Q's are calculated to be the same to five significant digits; exact agreement to more significant digits was not expected because only three significant digits are presented in the OBODM output. It should be noted that the source order in Tables A-2 and A-3 are source 1 is the Burn Pan, source 2 is the Burn Cage (Form 3), source 3 is the Burn Cage (Form 4), and source 4 is the Detonation Pad. The source order was set arbitrarily and changing it would necessitate many hours of work, with the possible introduction of error. The same source order was implemented in HARP.

Table A-4 shows the modified .XOQ file after the annual average and maximum hourly values were updated with OBODM X/Q values. The validity of the approach was checked by comparing the concentrations calculated by HARP for barium with those calculated by OBODM. The results were equal, confirming that the .XOQ file had been modified appropriately. This confirmatory calculation was carried out independently by two of the authors of this report, who obtained the same results. The calculations are shown in Table A-5, where 
the appropriate ground level concentrations for each of the sources are summed for the total annual average concentration and the maximum 1-hour concentration for each modeled receptor location. Figure A-1 is a screen shot of the annual average and maximum hourly ground level concentrations calculated by HARP.

Table A-1. Calculation of unit source values for two barium emission factors.

\begin{tabular}{|c|c|c|c|c|}
\hline & Burn pan & $\begin{array}{l}\text { Burn cage } \\
\text { (form 3) }\end{array}$ & $\begin{array}{l}\text { Burn cage } \\
\text { (form 4) }\end{array}$ & Detonation \\
\hline Barium factor $\mathbf{0 . 0 0 8 2}$ & \multicolumn{3}{|c|}{ Annual average emission rate } & \\
\hline Pounds per event & 100 & 50 & 260 & 350 \\
\hline Events per year & 100 & 100 & 100 & 100 \\
\hline Total pounds per year & 10000 & 5000 & 26000 & 35000 \\
\hline Total grams per year & 4535923 & 2267962 & 11793400 & 15875731 \\
\hline Total seconds per year & 31536000 & 31536000 & 31536000 & 31536000 \\
\hline Annual average g/s & 0.144 & 0.072 & 0.374 & 0.503 \\
\hline Barium emission factor & 0.0082 & 0.0082 & 0.0082 & 0.0082 \\
\hline \multirow[t]{2}{*}{ emission rate $(\mathrm{g} / \mathrm{s})$} & 0.00118 & 0.00059 & 0.00307 & 0.00413 \\
\hline & \multicolumn{3}{|c|}{ Maximum hourly emission rate } & \\
\hline Pounds per event & 100 & 50 & 260 & 350 \\
\hline Events per hour & 1 & 1 & 1 & 1 \\
\hline Total pounds per hour & 100 & 50 & 260 & 350 \\
\hline Total grams per hour & 45359 & 22680 & 117934 & 158757 \\
\hline Total seconds per hour & 3600 & 3600 & 3600 & 3600 \\
\hline Hourly g/s & 12.6 & 6.3 & 32.8 & 44.1 \\
\hline Barium emission factor & 0.0082 & 0.0082 & 0.0082 & 0.0082 \\
\hline $\begin{array}{l}\text { Barium maximum hourly } \\
\text { emission rate }(\mathrm{g} / \mathrm{s})\end{array}$ & 0.103 & 0.052 & 0.269 & 0.362 \\
\hline 0.000086 & \multicolumn{3}{|c|}{ Annual average emission rate } & \\
\hline Pounds & 100 & 50 & 260 & 350 \\
\hline Events per year & 100 & 100 & 100 & 100 \\
\hline Total pounds per year & 10000 & 5000 & 26000 & 35000 \\
\hline Total grams per year & 4535923 & 2267962 & 11793400 & 15875731 \\
\hline Total seconds per year & 31536000 & 31536000 & 31536000 & 31536000 \\
\hline Annual average $\mathrm{g} / \mathrm{s}$ & 0.144 & 0.072 & 0.374 & 0.503 \\
\hline Barium emission factor & 0.000086 & 0.000086 & 0.000086 & 0.000086 \\
\hline \multirow[t]{2}{*}{ emission rate $(\mathrm{g} / \mathrm{s})$} & 0.0000124 & 0.0000062 & 0.0000322 & 0.0000433 \\
\hline & \multicolumn{3}{|c|}{ Maximum hourly emission rate } & \\
\hline Poun & 100 & 50 & 260 & 350 \\
\hline Events & 1 & 1 & 1 & 1 \\
\hline Total pounds per hour & 100 & 50 & 260 & 350 \\
\hline Total grams per hour & 45359 & 22680 & 117934 & 158757 \\
\hline Total seconds per hour & 3600 & 3600 & 3600 & 3600 \\
\hline Hourly g/s & 12.6 & 6.3 & 32.8 & 44.1 \\
\hline Barium emission factor & 0.000086 & 0.000086 & 0.000086 & 0.000086 \\
\hline $\begin{array}{l}\text { Barlum maximum not } \\
\text { emission rate }(\mathrm{g} / \mathrm{s})\end{array}$ & 0.00108 & 0.00054 & 0.00282 & 0.00379 \\
\hline
\end{tabular}


Table A-2. Calculations of $X / Q$ based on barium emission factor of $\mathbf{0 . 0 0 8 2}$.

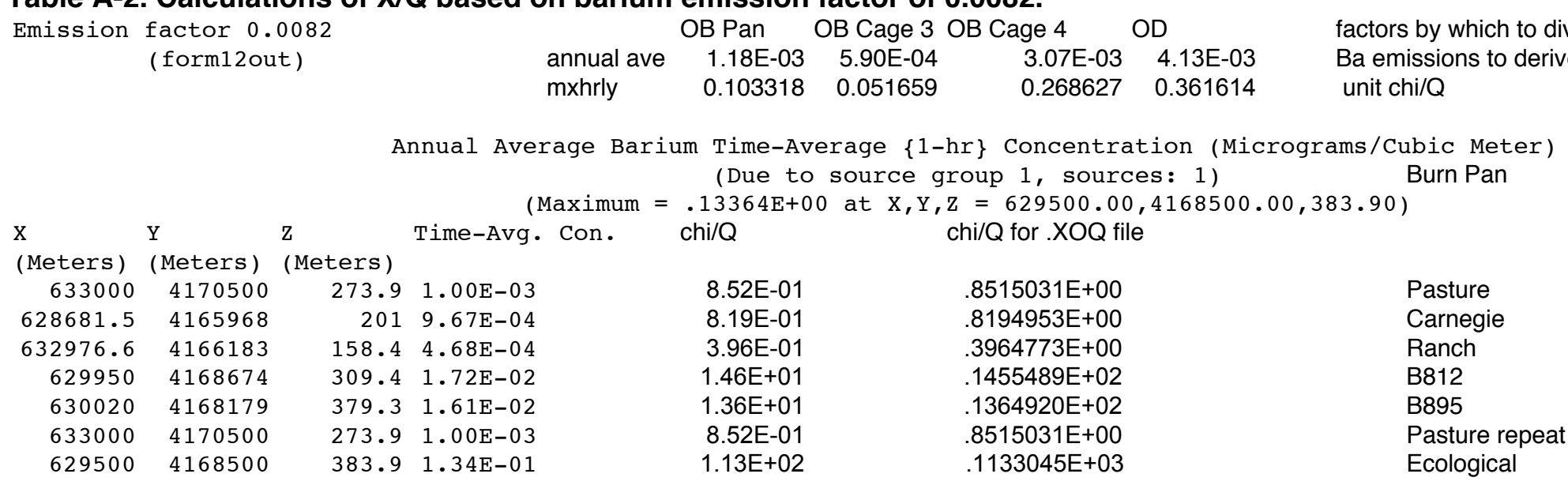

Table 3

Annual Average Barium Time-Average $\{1-\mathrm{h} r\}$ Concentration (Micrograms/Cubic Meter) (Due to source group 2, sources: 2 ) Burn Cage (form 3)

Maximum $=.66794 \mathrm{E}-01$ at $\mathrm{X}, \mathrm{Y}, \mathrm{Z}=629500,00,4168500.00,383.90)$

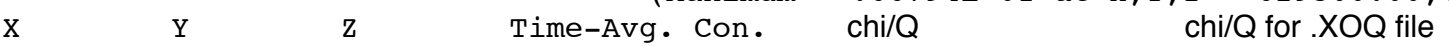

(Meters) (Meters) (Meters)

$\begin{array}{rrrrrr}633000 & 4170500 & 273.9 & 4.99 \mathrm{E}-04 & 8.47 \mathrm{E}-01 & .8469053 \mathrm{E}+00 \\ 628681.5 & 4165968 & 201 & 5.69 \mathrm{E}-04 & 9.65 \mathrm{E}-01 & .9646120 \mathrm{E}+00 \\ 632976.6 & 4166183 & 158.4 & 2.67 \mathrm{E}-04 & 4.52 \mathrm{E}-01 & .4522723 \mathrm{E}+00 \\ 629950 & 4168674 & 309.4 & 1.05 \mathrm{E}-02 & 1.78 \mathrm{E}+01 & .1782236 \mathrm{E}+02 \\ 630020 & 4168179 & 379.3 & 8.92 \mathrm{E}-03 & 1.51 \mathrm{E}+01 & .1511846 \mathrm{E}+02 \\ 633000 & 4170500 & 273.9 & 4.99 \mathrm{E}-04 & 8.47 \mathrm{E}-01 & .8469053 \mathrm{E}+00 \\ 629500 & 4168500 & 383.9 & 6.68 \mathrm{E}-02 & 1.13 \mathrm{E}+02 & .1132639 \mathrm{E}+03\end{array}$

Pasture

Carnegie

Ranch

B812

B895

Pasture repeat

Ecological

Table 4

Annual Average Barium Time-Average $\{1-\mathrm{hr}\}$ Concentration (Micrograms/Cubic Meter)

(Due to source group 3, sources: 3)
$($ Maximum $=.30209 \mathrm{E}+00$ at $X, Y, Z=629500.00,4168500.00,383.90)$

$\begin{array}{lll}\mathrm{X} & \mathrm{Y} & \mathrm{Z} \\ \text { (Meters) } & \text { (Meters) } & \text { (Meters) }\end{array}$

$\begin{array}{rrrrrr}633000 & 4170500 & 273.9 & 2.55 \mathrm{E}-03 & 8.33 \mathrm{E}-01 & .8327061 \mathrm{E}+00 \\ 628681.5 & 4165968 & 201 & 2.80 \mathrm{E}-03 & 9.14 \mathrm{E}-01 & .9135763 \mathrm{E}+00 \\ 632976.6 & 4166183 & 158.4 & 1.34 \mathrm{E}-03 & 4.37 \mathrm{E}-01 & .4365111 \mathrm{E}+00 \\ 629950 & 4168674 & 309.4 & 4.49 \mathrm{E}-02 & 1.46 \mathrm{E}+01 & .1463561 \mathrm{E}+02 \\ 630020 & 4168179 & 379.3 & 4.43 \mathrm{E}-02 & 1.44 \mathrm{E}+01 & .1443873 \mathrm{E}+02 \\ 633000 & 4170500 & 273.9 & 2.55 \mathrm{E}-03 & 8.33 \mathrm{E}-01 & .8327061 \mathrm{E}+00 \\ 629500 & 4168500 & 383.9 & 3.02 \mathrm{E}-01 & 9.85 \mathrm{E}+01 & .9851395 \mathrm{E}+02\end{array}$

chi/Q for .XOQ file

Burn Cage (form 4) 
Table A-2. Calculations of X/Q based on barium emission factor of 0.0082 (continued).

Table 5

Annual Average Barium Time-Average $\{1-\mathrm{hr}\}$ Concentration (Micrograms/Cubic Meter)

(Due to source group 4 , sources: 4 )

Detonation Pad

Maximum $=.12371 \mathrm{E}+00$ at $\mathrm{X}, \mathrm{Y}, \mathrm{Z}=629500.00,4168500.00,383.90)$

\begin{tabular}{|c|c|c|c|c|c|c|}
\hline $\begin{array}{l}\mathrm{X} \\
\text { (Meters) }\end{array}$ & $\begin{array}{l}Y \\
\text { (Meters) }\end{array}$ & $\begin{array}{l}\mathrm{z} \\
\text { (Meters) }\end{array}$ & Time-Avg. & Con. & chi/Q & chi/Q for .XOQ fil \\
\hline 633000 & 4170500 & 273.9 & $2.10 \mathrm{E}-03$ & & 5.08E-01 & $.5077556 \mathrm{E}+00$ \\
\hline 628681.5 & 4165968 & 201 & $2.19 E-03$ & & 5.31E-01 & $.5313214 \mathrm{E}+00$ \\
\hline 632976.6 & 4166183 & 158.4 & $1.26 \mathrm{E}-03$ & & 3.06E-01 & $.3058471 E+00$ \\
\hline 629950 & 4168674 & 309.4 & $1.72 \mathrm{E}-02$ & & 4.17E+00 & $.4165252 E+01$ \\
\hline 630020 & 4168179 & 379.3 & $2.44 \mathrm{E}-02$ & & $5.90 \mathrm{E}+00$ & $.5900567 E+01$ \\
\hline 633000 & 4170500 & 273.9 & $2.10 \mathrm{E}-03$ & & 5.08E-01 & $.5077556 \mathrm{E}+00$ \\
\hline 629500 & 4168500 & 383.9 & $1.24 \mathrm{E}-01$ & & $3.00 \mathrm{E}+01$ & $.2996747 \mathrm{E}+02$ \\
\hline
\end{tabular}

Pasture
Carnegie
Ranch
B812
B895
Pasture repeat
Ecological

Table 6

Highest Barium Time-Average $\{1-\mathrm{hr}\}$ Concentration (Micrograms/Cubic Meter)

(Due to source group 1, sources: 1) Burn Pan

$($ Maximum $=11.877$ at $X, Y, Z=629500.00,4168500.00,383.90$ ) Y Z Time-Avg. Con. chi/Q

chi/Q for .XOQ file Mo/ Dy/ Yr Jdy $\mathrm{Hr}$

(Meters) (Meters) (Meters) $\begin{array}{llll}633000 & 4170500 & 273.9 & 0.12558\end{array}$

$628681.5 \quad 4165968 \quad 201 \quad 0.223714$

$\begin{array}{llll}632976.6 & 4166183 & 158.4 & 0.114005\end{array}$

$\begin{array}{llll}629950 & 4168674 & 309.4 & 2.8726\end{array}$

$\begin{array}{llll}630020 & 4168179 \quad 379.3 \quad 2.95159\end{array}$

$\begin{array}{llll}633000 & 4170500 \quad 273.9 & 0.12558\end{array}$

$629500 \quad 4168500$

$383.9 \quad 11.887$

$1.22 \mathrm{E}+00$
$2.17 \mathrm{E}+00$
$1.10 \mathrm{E}+00$
$2.78 \mathrm{E}+01$
$2.86 \mathrm{E}+01$
$1.22 \mathrm{E}+00$
$1.15 \mathrm{E}+02$

$.1215471 E+01$
$.2165295 E+01$
$.1103438 E+01$
$.2780348 E+02$
$.2856801 E+02$
$.1215471 E+01$
$.1150526 E+03$

$\begin{array}{rrrrr}3 & 26 & 0 & 68 & 800 \\ 9 & 13 & 1 & 86 & 800 \\ 3 & 6 & 3 & 65 & 800 \\ 11 & 6 & 2 & 310 & 800 \\ 12 & 20 & 4 & 355 & 800 \\ 3 & 26 & 0 & 86 & 800 \\ 9 & 11 & 2 & 254 & 800\end{array}$

Table 8

Highest Barium Time-Average $\{1-\mathrm{hr}$ \} Concentration (Micrograms/Cubic Meter)

(Due to source group 2, sources: 2)

$($ Maximum $=5.0540$ at $X, Y, Z=629500.00,4168500.00,383.90)$

\begin{tabular}{|c|c|c|c|c|c|c|c|c|c|c|c|c|}
\hline $\begin{array}{l}\mathrm{x} \\
\text { (Meters) }\end{array}$ & $\begin{array}{l}Y \\
\text { (Meters) }\end{array}$ & $\begin{array}{l}\mathrm{Z} \\
\text { (Meters) }\end{array}$ & Time-Avg. & Con. & chi/Q & chi/Q for .XOQ file & Mo/ & Dy/ & Yr & & dy & $\mathrm{Hr}$ \\
\hline 633000 & 4170500 & 273.9 & 0.500138 & & $9.68 \mathrm{E}+00$ & $.9681527 E+01$ & 12 & 6 & 6 & 2 & 340 & 800 \\
\hline 628681.5 & 4165968 & 201 & $8.33 E-02$ & & $1.61 \mathrm{E}+00$ & $.1612037 \mathrm{E}+01$ & 9 & 13 & & 1 & 256 & 800 \\
\hline 632976.6 & 4166183 & 158.4 & 0.040661 & & 7.87E-01 & $.7870981 E+00$ & 3 & 6 & 6 & 3 & 65 & 800 \\
\hline 629950 & 4168674 & 309.4 & 1.3717 & & $2.66 \mathrm{E}+01$ & $.2655297 \mathrm{E}+02$ & 1 & 19 & & 4 & 19 & 900 \\
\hline 630020 & 4168179 & 379.3 & 1.17555 & & $2.28 \mathrm{E}+01$ & $.2275596 \mathrm{E}+02$ & 11 & 25 & & 0 & 330 & 800 \\
\hline 633000 & 4170500 & 273.9 & 0.500138 & & $9.68 \mathrm{E}+00$ & $.9681527 \mathrm{E}+01$ & 12 & 6 & 5 & 2 & 340 & 800 \\
\hline 629500 & 4168500 & 383.9 & 5.05396 & & $9.78 \mathrm{E}+01$ & $.9783310 \mathrm{E}+02$ & 9 & 11 & & 2 & 254 & 800 \\
\hline
\end{tabular}


Table A-2. Calculations of $X / Q$ based on barium emission factor of 0.0082 (continued).

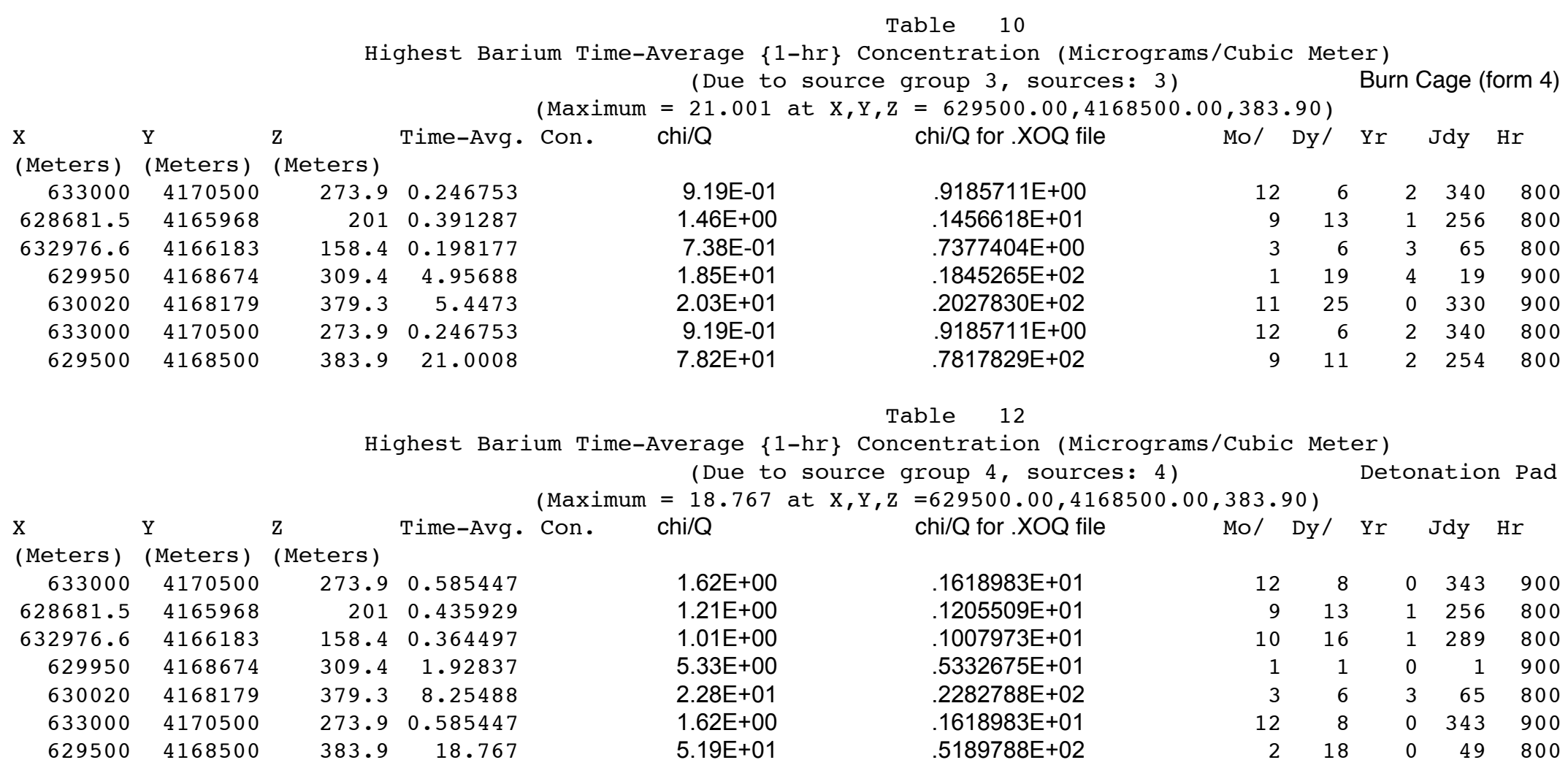


Table A-3. Calculations of $X / Q$ based on barium emission factor of 0.000086 .

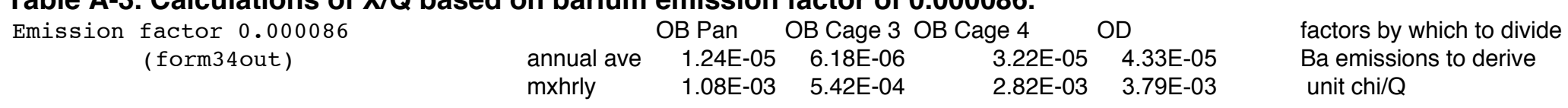

Annual Average Barium Time-Average $\{1-\mathrm{hr}\}$ Concentration (Micrograms/Cubic Meter) (Due to source group 1 , sources: 1 ) Burn Pan

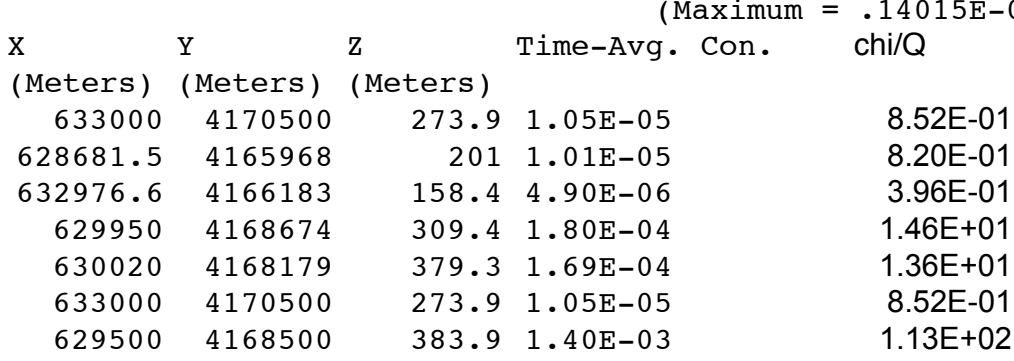

$$
\text { chi/Q for .XOQ file }
$$

$.8515033 E+00$
$.8196673 E+00$
$.3964776 E+00$
$.1455489 E+02$
$.1364921 E+02$
$.8515033 E+00$
$.1133047 E+03$

Pasture Carnegie

Ranch

B812

B895

Pasture repeat

Ecological

Table 3

Annual Average Barium Time-Average $\{1-\mathrm{hr}\}$ Concentration (Micrograms/Cubic Meter) (Due to source group 2 , sources: 2 ) Burn Cage (form 3)

\begin{tabular}{|c|c|c|c|c|c|c|}
\hline $\begin{array}{l}\mathrm{X} \\
\text { (Meters) }\end{array}$ & $\begin{array}{l}\mathrm{Y} \\
\text { (Meters) }\end{array}$ & $\begin{array}{l}\mathrm{z} \\
\text { (Meters) }\end{array}$ & Time-Avg. Con. & chi/Q & chi/Q for .XOQ file & \\
\hline 633000 & 4170500 & 273.9 & $5.24 \mathrm{E}-06$ & 8.47E-01 & $.8469114 \mathrm{E}+00$ & Pasture \\
\hline 628681.5 & 4165968 & 201 & $5.97 \mathrm{E}-06$ & $9.65 E-01$ & $.9646204 \mathrm{E}+00$ & Carnegie \\
\hline 632976.6 & 4166183 & 158.4 & $2.80 \mathrm{E}-06$ & $4.52 \mathrm{E}-01$ & $.4522762 E+00$ & Ranch \\
\hline 629950 & 4168674 & 309.4 & $1.10 \mathrm{E}-04$ & $1.78 \mathrm{E}+01$ & $.1782249 E+02$ & B812 \\
\hline 630020 & 4168179 & 379.3 & $9.35 \mathrm{E}-05$ & $1.51 \mathrm{E}+01$ & $.1511861 E+02$ & B895 \\
\hline 633000 & 4170500 & 273.9 & $5.24 \mathrm{E}-06$ & $8.47 \mathrm{E}-01$ & $.8469114 \mathrm{E}+00$ & Pasture repeat \\
\hline 629500 & 4168500 & 383.9 & $7.01 \mathrm{E}-04$ & 1.13E+02 & $.1132646 E+03$ & Ecological \\
\hline
\end{tabular}

Table 4

Annual Average Barium Time-Average $\{1-\mathrm{hr}\}$ Concentration (Micrograms/Cubic Meter) (Due to source group 3 , sources: 3 )
$1683 \mathrm{E}-02$ at $\mathrm{X}, \mathrm{Y}, \mathrm{Z}=629500.00,4168500.00,383.90$

$\mathrm{X}$ $\begin{array}{llllr}X & Y & Z & \text { Time-Avg. Con. } & \text { chi/Q } \\ \text { (Meters) } & \text { (Meters) } & \text { (Meters) } & & \\ 633000 & 4170500 & 273.9 & 2.68 \mathrm{E}-05 & 8.33\end{array}$ $628681.5 \quad 4165968$ $632976.6 \quad 4166183$ $629950 \quad 4168674$ $630020 \quad 4168179$ $633000 \quad 4170500$ $629500 \quad 4168500$

$\begin{array}{rrr}273.9 & 2.68 \mathrm{E}-05 & 8.33 \mathrm{E}-01 \\ 201 & 2.94 \mathrm{E}-05 & 9.14 \mathrm{E}-01 \\ 158.4 & 1.40 \mathrm{E}-05 & 4.37 \mathrm{E}-01 \\ 309.4 & 4.71 \mathrm{E}-04 & 1.46 \mathrm{E}+01 \\ 379.3 & 4.49 \mathrm{E}-04 & 1.39 \mathrm{E}+01 \\ 273.9 & 2.68 \mathrm{E}-05 & 8.33 \mathrm{E}-01 \\ 383.9 & 3.17 \mathrm{E}-03 & 9.85 \mathrm{E}+01\end{array}$

chi/Q for .XOQ file

$$
\begin{aligned}
& .8327048 \mathrm{E}+00 \\
& .9135758 \mathrm{E}+00 \\
& .4365087 \mathrm{E}+00 \\
& .1463560 \mathrm{E}+02 \\
& .1394629 \mathrm{E}+02 \\
& .8327048 \mathrm{E}+00 \\
& .9851374 \mathrm{E}+02
\end{aligned}
$$

Burn Cage (form 4)
Pasture

Carnegie

Ranch

B812

B895

Pasture repeat

Ecological 
Table A-3. Calculations of $X / Q$ based on barium emission factor of 0.000086 (continued).

Table 5

Annual Average Barium Time-Average $\{1-\mathrm{hr}\}$ Concentration (Micrograms/Cubic Meter)

(Due to source group 4, sources: 4) Detonation Pad

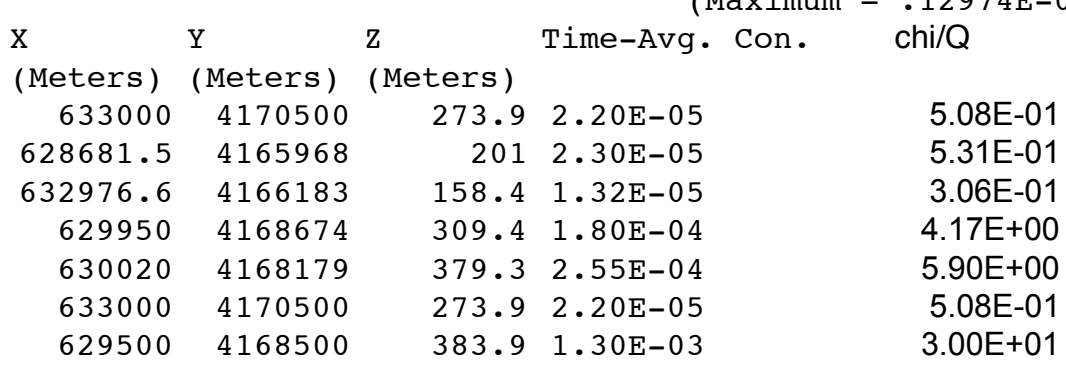

chi/Q for .XOQ file

Q $. X 0 Q 7542 \mathrm{E}+00$

3058453E+00 Ranch

4165263E+01 B812

$.5900570 \mathrm{E}+01$

$.5077542 \mathrm{E}+00 \quad$ Pasture repeat

$.2996758 \mathrm{E}+02 \quad$ Ecological

Table 6

Highest Barium Time-Average $\{1-\mathrm{h} r\}$ Concentration (Micrograms/Cubic Meter) (Due to source group 1 , sources: 1 ) Burn Pan

$($ Maximum $=.12456 \mathrm{E}+00$ at $\mathrm{X}, \mathrm{Y}, \mathrm{Z}=629500.00,4168500.00,383.90)$

\begin{tabular}{|c|c|c|c|c|c|c|c|c|c|c|c|c|}
\hline $\begin{array}{l}\mathrm{x} \\
\text { (Meters) }\end{array}$ & $\begin{array}{l}\mathrm{Y} \\
\text { (Meters) }\end{array}$ & $\begin{array}{l}z \\
\text { (Meters) }\end{array}$ & Time-Avg. & Con. & chi/Q & chi/Q for .XOQ file & Mo/ & Dy / & $\mathrm{Yr}$ & & dy & $\mathrm{Hr}$ \\
\hline 633000 & 4170500 & 273.9 & $1.32 \mathrm{E}-03$ & & $1.22 \mathrm{E}+00$ & $.1215469 E+01$ & 3 & 26 & 6 & 0 & 86 & 800 \\
\hline 628681.5 & 4165968 & 201 & $2.35 E-03$ & & $2.17 E+00$ & $.2165291 \mathrm{E}+01$ & 9 & 13 & 3 & 1 & 256 & 800 \\
\hline 632976.6 & 4166183 & 158.4 & $1.20 \mathrm{E}-03$ & & $1.10 \mathrm{E}+00$ & $.1103433 E+01$ & 3 & & 6 & 3 & 65 & 800 \\
\hline 629950 & 4168674 & 309.4 & $3.01 \mathrm{E}-02$ & & $2.78 \mathrm{E}+01$ & $.2780344 \mathrm{E}+02$ & 11 & & 6 & 2 & 310 & 800 \\
\hline 630020 & 4168179 & 379.3 & $3.10 \mathrm{E}-02$ & & $2.86 E+01$ & $.2856794 \mathrm{E}+02$ & 12 & 20 & 0 & 4 & 355 & 800 \\
\hline 633000 & 4170500 & 273.9 & 1. $32 \mathrm{E}-03$ & & $1.22 \mathrm{E}+00$ & $.1215469 E+01$ & 3 & 26 & 6 & 0 & 86 & 800 \\
\hline 629500 & 4168500 & 383.9 & $1.25 E-01$ & & $1.15 E+02$ & $.1149549 E+03$ & 9 & 1. & 1 & 2 & 254 & 800 \\
\hline
\end{tabular}

Table 8

Highest Barium Time-Average $\{1-\mathrm{hr}\}$ Concentration (Micrograms/Cubic Meter)

(Due to source group 2, sources: 2 )

Burn Cage (form 3)

$($ Maximum $=.53005 \mathrm{E}-01$ at $\mathrm{X}, \mathrm{Y}, \mathrm{Z}=629500.00,4168500.00,383.90)$

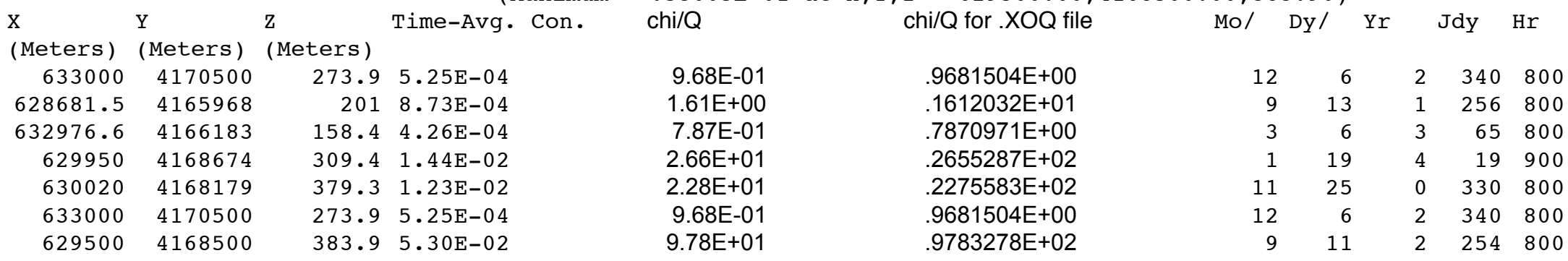


Table A-3. Calculations of $X / Q$ based on barium emission factor of 0.000086 (continued).

$$
\text { Table } 10
$$

Highest Barium Time-Average $\{1-\mathrm{hr}\}$ Concentration (Micrograms/Cubic Meter)

(Due to source group 3, sources: 3 )

Burn Cage (form 4)

\begin{tabular}{|c|c|c|c|c|c|}
\hline & Y & z & Time-Avg. Con. & chi/Q & chi/Q for .XOQ fi \\
\hline 633000 & 4170500 & 273.9 & $2.59 \mathrm{E}-03$ & $9.19 E-01$ & $.9185705 E+0$ \\
\hline 628681.5 & 4165968 & 201 & $4.10 \mathrm{E}-03$ & $1.46 \mathrm{E}+00$ & $.1456615 \mathrm{E}+$ \\
\hline 632976.6 & 4166183 & 158.4 & $2.08 E-03$ & 7.38E-01 & $.7377422 \mathrm{E}+$ \\
\hline 629950 & 4168674 & 309.4 & $5.20 \mathrm{E}-02$ & $1.85 E+01$ & $.1845262 E+$ \\
\hline 630020 & 4168179 & 379.3 & $5.71 \mathrm{E}-02$ & $2.03 E+01$ & $.2027826 E+C$ \\
\hline 633000 & 4170500 & 273.9 & $2.59 E-03$ & 9.19E-01 & $.9185705 E+$ \\
\hline 629500 & 4168500 & 383.9 & $2.20 \mathrm{E}-01$ & $7.82 E+01$ & $.7817806 \mathrm{E}+$ \\
\hline
\end{tabular}

Table 12

Highest Barium Time-Average $\{1-\mathrm{hr}\}$ Concentration (Micrograms/Cubic Meter)

(Due to source group 4, sources: 4) Detonation Pad

\begin{tabular}{|c|c|c|c|c|c|c|c|c|c|c|c|}
\hline $\begin{array}{l}\mathrm{X} \\
\text { (Meters) }\end{array}$ & $\begin{array}{l}\mathrm{Y} \\
\text { (Meters) }\end{array}$ & $\begin{array}{l}\mathrm{Z} \\
\text { (Meters) }\end{array}$ & Time-Avg. Con. & chi/Q & $\begin{array}{l}Z=629500.00 \\
\text { chi/Q for } . X O Q \text { file }\end{array}$ & $\begin{array}{l}00,3 \varepsilon \\
\text { Mo/ }\end{array}$ & $\begin{array}{c}3.90 \\
\text { Dy/ }\end{array}$ & Yr & & dy & $\mathrm{Hr}$ \\
\hline 633000 & 4170500 & 273.9 & $6.14 \mathrm{E}-03$ & $1.62 E+00$ & $.1618983 E+01$ & 12 & & 8 & 0 & 343 & 900 \\
\hline 628681.5 & 4165968 & 201 & $4.57 \mathrm{E}-03$ & $1.21 \mathrm{E}+00$ & $.1205510 E+01$ & 9 & & 13 & 1 & 256 & 800 \\
\hline 632976.6 & 4166183 & 158.4 & $3.82 E-03$ & $1.01 \mathrm{E}+00$ & $.1007972 E+01$ & 10 & & 16 & 1 & 289 & 800 \\
\hline 629950 & 4168674 & 309.4 & $2.02 E-02$ & $5.33 E+00$ & $.5332685 E+01$ & 1 & & 1 & 0 & 1 & 900 \\
\hline 630020 & 4168179 & 379.3 & $8.66 \mathrm{E}-02$ & $2.28 \mathrm{E}+01$ & $.2282787 E+02$ & 3 & & 6 & 3 & 65 & 800 \\
\hline 633000 & 4170500 & 273.9 & $6.14 \mathrm{E}-03$ & $1.62 \mathrm{E}+00$ & $.1618983 E+01$ & 12 & & 8 & 0 & 343 & 900 \\
\hline 629500 & 4168500 & 383.9 & $1.97 \mathrm{E}-01$ & $5.19 E+01$ & $.5189800 E+02$ & 2 & & 8 & 0 & 49 & 800 \\
\hline
\end{tabular}
Mo/ Mo/ Dy/ Yr Jdy $\mathrm{Hr}$

$\begin{array}{rrrrr}12 & 6 & 2 & 340 & 800 \\ 9 & 13 & 1 & 256 & 800 \\ 3 & 6 & 3 & 65 & 800 \\ 1 & 19 & 4 & 19 & 900 \\ 11 & 25 & 0 & 330 & 800 \\ 12 & 6 & 2 & 340 & 800 \\ 9 & 11 & 2 & 254 & 800\end{array}$


Table A-4. Modified .XOQ file after the annual average and maximum hourly values were updated with OBODM $X / Q$ values. (Other values in .XOQ files were not used in this risk assessment).

\begin{tabular}{|c|c|c|c|c|c|c|c|}
\hline SRC & REC & UNUSED & AVERAGE & 1HR_MAX & . $\cdot$ & - (additional columns, not used in this & assessment) \\
\hline 1 & 1 & $0.3961217 \mathrm{E}+00$ & $0.8515033 \mathrm{E}+00$ & $0.1215469 \mathrm{E}+01$ & . $\cdot$ & • & \\
\hline 1 & 2 & $0.2721988 \mathrm{E}-02$ & $0.8196673 \mathrm{E}+00$ & $0.2165291 \mathrm{E}+01$ & . $\cdot$ & • & \\
\hline 1 & 3 & $0.2719286 \mathrm{E}-02$ & $0.3964776 \mathrm{E}+00$ & $0.1103433 \mathrm{E}+01$ & . $\cdot$ & • & \\
\hline 1 & 4 & $0.2839895 \mathrm{E}-02$ & $0.1455489 \mathrm{E}+02$ & $0.2780344 \mathrm{E}+02$ & . . & . & \\
\hline 1 & 5 & $0.3750449 \mathrm{E}-01$ & $0.1364921 \mathrm{E}+02$ & $0.2856794 \mathrm{E}+02$ & . . & . & \\
\hline 1 & 6 & $0.2341939 \mathrm{E}-01$ & $0.8515033 E+00$ & $0.1215469 \mathrm{E}+01$ & . . & • & \\
\hline 1 & 7 & $0.2341939 \mathrm{E}-01$ & $0.1133047 \mathrm{E}+03$ & $0.1149549 \mathrm{E}+03$ & . . & • & \\
\hline 2 & 1 & $0.4261317 \mathrm{E}+00$ & $0.8469114 \mathrm{E}+00$ & $0.9681504 \mathrm{E}+00$ & . $\cdot$ & • & \\
\hline 2 & 2 & $0.3105313 \mathrm{E}-02$ & $0.9646204 \mathrm{E}+00$ & $0.1612032 \mathrm{E}+01$ & . $\cdot$ & - & \\
\hline 2 & 3 & $0.4173856 \mathrm{E}-01$ & $0.4522762 \mathrm{E}+00$ & $0.7870971 \mathrm{E}+00$ & . $\cdot$ & - & \\
\hline 2 & 4 & $0.2657336 \mathrm{E}-01$ & $0.1782249 \mathrm{E}+02$ & $0.2655287 \mathrm{E}+02$ & . . & • & \\
\hline 2 & 5 & $0.8583720 \mathrm{E}+00$ & $0.1511861 \mathrm{E}+02$ & $0.2275583 E+02$ & . . & • & \\
\hline 2 & 6 & $0.1174408 \mathrm{E}+01$ & $0.8469114 \mathrm{E}+00$ & $0.9681504 \mathrm{E}+00$ & . $\cdot$ & • & \\
\hline 2 & 7 & $0.2341939 \mathrm{E}-01$ & $0.1132646 \mathrm{E}+03$ & $0.9783278 \mathrm{E}+02$ & . . & . & \\
\hline 3 & 1 & $0.4261317 \mathrm{E}+00$ & $0.8327048 \mathrm{E}+00$ & $0.9185705 \mathrm{E}+00$ & . $\cdot$ & • & \\
\hline 3 & 2 & $0.3105313 \mathrm{E}-02$ & $0.9135758 \mathrm{E}+00$ & $0.1456615 \mathrm{E}+01$ & . $\cdot$ & • & \\
\hline 3 & 3 & $0.4173856 \mathrm{E}-01$ & $0.4365087 \mathrm{E}+00$ & $0.7377422 \mathrm{E}+00$ & . . & • & \\
\hline 3 & 4 & $0.2657336 \mathrm{E}-01$ & $0.1463560 \mathrm{E}+02$ & $0.1845262 \mathrm{E}+02$ & . . & - & \\
\hline 3 & 5 & $0.8583720 \mathrm{E}+00$ & $0.1394629 \mathrm{E}+02$ & $0.2027826 \mathrm{E}+02$ & . . & • & \\
\hline 3 & 6 & $0.1174408 \mathrm{E}+01$ & $0.8327048 \mathrm{E}+00$ & $0.9185705 \mathrm{E}+00$ & - & • & \\
\hline 3 & 7 & $0.2341939 \mathrm{E}-01$ & $0.9851374 \mathrm{E}+02$ & $0.7817806 \mathrm{E}+02$ & . $\cdot$ & • & \\
\hline 4 & 1 & $0.2331261 \mathrm{E}+00$ & $0.5077542 \mathrm{E}+00$ & $0.1618983 \mathrm{E}+01$ & . $\cdot$ & • & \\
\hline 4 & 2 & $0.2328404 \mathrm{E}-02$ & $0.5313210 \mathrm{E}+00$ & $0.1205510 \mathrm{E}+01$ & • & • & \\
\hline 4 & 3 & $0.3221262 \mathrm{E}-01$ & $0.3058453 \mathrm{E}+00$ & $0.1007972 \mathrm{E}+01$ & . • & - & \\
\hline 4 & 4 & $0.1822067 \mathrm{E}-01$ & $0.4165263 \mathrm{E}+01$ & $0.5332685 \mathrm{E}+01$ & . $\cdot$ & • & \\
\hline 4 & 5 & $0.7229874 \mathrm{E}+00$ & $0.5900570 \mathrm{E}+01$ & $0.2282787 \mathrm{E}+02$ & - $\quad$. & - & \\
\hline 4 & 6 & $0.9328276 \mathrm{E}+00$ & $0.5077542 \mathrm{E}+00$ & $0.1618983 \mathrm{E}+01$ & - & • & \\
\hline 4 & 7 & $0.2341939 \mathrm{E}-01$ & $0.2996758 \mathrm{E}+02$ & $0.5189800 \mathrm{E}+02$ & . . & - & \\
\hline
\end{tabular}


Table A-5. Total ground level concentration of barium for all four sources by receptor location. The Burn Pan (source 1) and Detonation Pad (source 4) values are obtained from Table A-2, and the Burn Cage/Form 3 (source 2) and Burn Cage/Form 4 (source 3) values are obtained from Table A-3.

\begin{tabular}{|c|c|c|c|c|}
\hline \multicolumn{5}{|c|}{ Annual average } \\
\hline Location & $\begin{array}{l}\text { X (UTM East) } \\
\text { (Meters) }\end{array}$ & $\begin{array}{l}\text { Y ( UTM North) } \\
\text { (Meters) }\end{array}$ & $\begin{array}{l}\text { Z } \\
\text { (Elevation) } \\
\text { (Meters) }\end{array}$ & $\begin{array}{l}\text { Ground Level } \\
\text { Concentration } \\
\mu \mathrm{g} / \mathrm{m} 3\end{array}$ \\
\hline Pasture & 633000 & 4170500 & 273.9 & $3.13 E-03$ \\
\hline Carnegie & 628681.5 & 4165968 & 201 & $3.20 \mathrm{E}-03$ \\
\hline Ranch & 632976.6 & 4166183 & 158.4 & $1.75 \mathrm{E}-03$ \\
\hline B812 & 629950 & 4168674 & 309.4 & $3.49 \mathrm{E}-02$ \\
\hline B895 & 630020 & 4168179 & 379.3 & $4.10 \mathrm{E}-02$ \\
\hline Pasture & & & & \\
\hline repeat & 633000 & 4170500 & 273.9 & $3.13 \mathrm{E}-03$ \\
\hline Ecological & 629500 & 4168500 & 383.9 & $2.61 \mathrm{E}-01$ \\
\hline \multicolumn{5}{|c|}{ Maximum 1 hour } \\
\hline Location & $\begin{array}{l}\text { X (UTM East) } \\
(\text { Meters) }\end{array}$ & $\begin{array}{l}\text { Y ( UTM North) } \\
\text { (Meters) }\end{array}$ & $\begin{array}{l}\text { Z } \\
\text { (Elevation) } \\
\text { (Meters) }\end{array}$ & $\begin{array}{l}\text { Ground Level } \\
\text { Concentration } \\
\mu \mathrm{g} / \mathrm{m} 3\end{array}$ \\
\hline Pasture & 633000 & 4170500 & 273.9 & $7.14 \mathrm{E}-01$ \\
\hline Carnegie & 628681.5 & 4165968 & 201 & $6.65 \mathrm{E}-01$ \\
\hline Ranch & 632976.6 & 4166183 & 158.4 & $4.81 \mathrm{E}-01$ \\
\hline B812 & 629950 & 4168674 & 309.4 & $4.87 E+00$ \\
\hline B895 & 630020 & 4168179 & 379.3 & $1.13 \mathrm{E}+01$ \\
\hline Pasture & & & & \\
\hline repeat & 633000 & 4170500 & 273.9 & $7.14 \mathrm{E}-01$ \\
\hline Ecological & 629500 & 4168500 & 383.9 & $3.09 \mathrm{E}+01$ \\
\hline
\end{tabular}

Figure A-1. Screen captures of total ground level concentrations for HARP for barium (CAS number 7440393 ).

\begin{tabular}{|c|c|c|c|c|c|c|c|}
\hline Avrg & Max $1 \mathrm{Hr}$ & $\operatorname{Max} 4 \mathrm{Hr}$ & $\operatorname{Max}$ & Avrg & $\operatorname{Max} 1 \mathrm{Hr}$ & $\operatorname{Max} 4 \mathrm{Hr}$ & $\operatorname{Max}$ \\
\hline \multirow[t]{2}{*}{ Rec } & Type & CAS 7440393 & CAS & Rec & Type & CAS 7440393 & CAS \\
\hline & & $\mathrm{ug} / \mathrm{m}^{\wedge} 3$ & $\mathrm{ug} / \mathrm{m}$ & & & $\mathrm{ug} / \mathrm{m}^{\wedge} 3$ & $\mathrm{ug} / \mathrm{m}$ \\
\hline 1 & PATHWAY & $3.13 \mathrm{E}-03$ & 2. & 1 & PATHW/AY & $7.14 \mathrm{E}-01$ & 2 \\
\hline 2 & SENSITIVE & $3.20 \mathrm{E}-03$ & 2. & 2 & SENSITIVE & $6.65 \mathrm{E}-01$ & 3. \\
\hline 3 & SENSITIVE & $1.75 \mathrm{E}-03$ & 1. & 3 & SENSITIVE & $4.81 E-01$ & 1. \\
\hline 4 & SENSITIVE & $3.49 E-02$ & 3. & 4 & SENSITIVE & $4.87 \mathrm{E}+00$ & 4. \\
\hline 5 & SENSITIVE & 4.10E-02 & 3. & 5 & SENSITIVE & $1.13 \mathrm{E}+01$ & 5. \\
\hline 6 & SENSITIVE & $3.13 E-03$ & 2. & 6 & SENSITIVE & $7.14 \mathrm{E}-01$ & 2. \\
\hline 7 & SENSITIVE & 2.61E-01 & 2. & 7 & SENSITIVE & $3.09 \mathrm{E}+01$ & 1.8 \\
\hline
\end{tabular}

Note: The pathway location (for the beef ingestion pathway) was repeated as the number 6 "sensitive" location (for a person) in HARP to assure that the final result was a risk value for a person at that location, and not some other type of receptor, e.g., a cow. The pathway location was necessary for HARP to calculate a human ingestion dose from the beef pathway. 


\section{References}

Bjorklund, J. R., J. F. Bowers, G. C. Dodd, and J. M. White (1998), Open Burn/Open Detonation Dispersion Model (OBODM) User's Guide, West Desert Test Center, Dugway Proving Ground, Dugway, UT (DPG Document No. DPG-TR-96-008a) (http://www.epa.gov/scram001/tt22.htm ).

California Environmental Protection Agency, Air Resources Board (CARB) (2003), HotSpots Analysis and Reporting Program User Guide, Developed by Dillingham Software Engineering, Inc., Air Resources Board, Stationary Source Division, Sacramento, California.

National Academy of Sciences (NAS) (1983), Risk Assessment in the Federal Government. Managing the Process. National Academy Press, Washington, DC.

Office of Environmental Health Hazard Assessment (OEHHA) (2003), Air Toxics Hot Spots Program Risk Assessment Guidelines The Air Toxics Hot Spots Program Guidance Manual for Preparation of Health Risk Assessments, Office of Environmental Health Hazard Assessment, California Environmental Protection Agency, Oakland, California.

United States Environmental Protection Agency (U.S. EPA) (2002), Draft Final Open Burning/Open Detonation Permitting Guidelines (Tetra Tech, Inc., prepared for U.S. Environmental Protection Agency, Region III, Philadelphia, PA, February 2002). 


\section{Appendix B. Ecological Risk Assessment in Support of Renewal of the Permit for the Explosive Waste Treatment Facility (EWTF) at Site $\mathbf{3 0 0}$ of the Lawrence Livermore National Laboratory}

\section{Introduction}

This ecological risk assessment (ERA) is a supplement to the human-health risk assessment (HRA) for the EWTF and was conducted according to currently accepted practice, which is described in detail in this Appendix.

There are four steps in the ERA analysis process:

1) Identify each contaminant of potential ecological concern (CPEC) in emissions from $\mathrm{OB} / \mathrm{OD}$ operations, which also have toxic reference values (TRVs) available in the literature;

2) Combine the concentration of each CPEC deposited in the habitat near the $\mathrm{OB} / \mathrm{OD}$ operations, as determined by atmospheric dispersion and deposition modeling, with the relevant exposure-pathways applicable to each organism considered a representative receptor of ecological interest (RREI) to determine a pathway-specific dose from a CPEC for a RREI;

3) Sum the exposure-pathway doses from a CPEC for a RREI to obtain a total dose for that RREI from that CPEC; and

4) Develop an "ecological hazard quotient" (EHQ) [i.e., ratio of total daily dose from a CPEC for an RREI to a not-to-be exceeded toxic reference value (TRV)] for each CPEC and RREI as a quantitative metric for evaluating whether there is any significant potential for adverse effects on RREI populations in the habitat near the EWTF as a result of possible $\mathrm{CPEC}$ emissions from its $\mathrm{OB} / \mathrm{OD}$ operations.

The heavy metals cadmium $(\mathrm{Cd})$, copper $(\mathrm{Cu})$, lead $(\mathrm{Pb})$, and zinc $(\mathrm{Zn})$ and six specific congeners of polychlorinated dibenzo-p-dioxins and dibenzofurans (PCDDs/PCDFs) each equate to a CPEC. These particular CPECs are important because they are considered to be potential emissions from OB/OD operations with possible biological significance for each RREI in the vicinity of the EWTF, and because there is a TRV available in the literature for each one of them. The California Ground Squirrel (Spermophilus beecheyi); the San Joaquin Kit Fox (Vulpes macrotis mutica), the Burrowing Owl (Athene cunicularia), and the Blacktailed Deer (Odocoileus hemionus columbianus) each equate to a RREI. The Ground Squirrel, Kit Fox, and Burrowing Owl are all fossorial (i.e., burrowing), whereas the Black-Tailed Deer is nonfossorial.

The San Joaquin Kit Fox and Burrowing Owl are considered to represent a different level of the food chain than either the squirrel [a prey that is considered to be the entire diet for the Kit Fox (based on information used by Carlsen, 1996) and $50 \%$ of the diet for the Burrowing Owl (based on information noted by Biermann et al., 2001)] or the Black-tailed Deer [which, like the squirrel, is considered to be herbivorous (based on information used by Carlsen, 1996)]. Thus, the technical basis for this ERA is a quantitative analysis that screens each CPEC with respect to its potential for producing an adverse effect in each RREI. 


\section{Source Term}

The EWTF OB / OD operations at Site 300 represent the source term. As described in the text, these operations involve open detonation of Waste Form 1 (waste explosives that otherwise might detonate during open burning); open burning in a burn pan of Waste Form 2 (waste explosives or explosive parts); and open burning in a burn cage of either Waste Form 3 (waste explosives that are wetted in processing or as a result of removal from waste water as sludge from weirs and settling basins or on wetted expendable filters) or Waste Form 4 (explosives contaminated waste materials including paper, rags, plastic tubing, gloves and personal protective equipment). Emissions are estimated based on planned quantities of materials to be treated: Waste Form 1 (OD treatment) is considered to involve 100 annual treatments of 350 pounds each; Waste Form 2 (OB-pan) is considered to involve 100 annual treatments of 100 pounds each; Waste Form 3 (OB-cage) is considered to involve 100 annual treatments of 50 pounds each; and Waste Form 4 (OB-cage) is considered to involve 100 annual treatments of 260 pounds each. For this ERA, the OBODM/HARP models (see Bjorklund et al., 1998; and CARB, 2003) were linked to estimate concentrations of each CPEC at a location near the OD pad, OB burn pan, and OB burn cage (all of which are in close proximity) at the EWTF, which is isolated in a small canyon at about the center of Site 300 (see Figures 2 through 6 in the text). For this location, the concentrations of interest are the maximum annual soil concentrations over two different depths: $1-\mathrm{cm}$ and $15-\mathrm{cm}$. The concentration at $1-\mathrm{cm}$ depth is a conservative estimate for considering only the resuspension of contaminated soil above ground.

\section{Relevant Exposure Pathways for Each RREI}

The individual exposure pathways considered relevant for each RREI are inhalation of CPEC-contaminated soil particulates resuspended into air; incidental ingestion of CPEC-contaminated soil particles; and ingestion of forage or prey for which uptake of a CPEC from soil is estimated using a calculated uptake factor. The intake of contaminated water by an RREI is not addressed in this ERA because there are no significant water bodies in the area of maximum exposure near the EWTF at Site 300. Additionally, for purposes of conservatism, all RREI living, foraging, and prey capturing is considered to occur exclusively in the habitat nearest OB/OD operations, where highest concentrations of each CPEC are predicted by modeling to be deposited, and the absorption fraction of each CPEC from the lungs and intestinal tract of each RREI is considered to be $100 \%$.

The soil concentration over a 1-cm depth is computed for purposes of considering resuspension at the surface; and the soil concentration over a $15-\mathrm{cm}$ depth is computed for purposes of considering resuspension in burrows, and also for addressing incidental soil ingestion, and uptake by forage and prey of each CPEC. These estimated maximum annual soil concentrations in habitat nearest the OB/OD operations of the EWTF are used because if these concentrations are unlikely to be of concern, then the lower concentrations predicted at more distant locations also are unlikely to be of concern. 


\section{Habitat}

Site 300 itself is hilly, natural grassland habitat, and only about $5 \%$ of this $11 \mathrm{mi}^{2}$ site is even developed. Put into perspective, the vast majority of this site is undeveloped and mostly undisturbed land on which a diversity of wildlife does exist (DOE/NNSA, 2004). Furthermore, because it is a high explosives testing area, Site 300 has no public access, and is subject to controlled burns. These two factors prevent impacts from grazing and maintain natural biodiversity.

\section{Identification of RREls and CPECs}

As a consequence of the location and habitat of Site 300, and particularly the habitat near the EWTF at Site 300, the wildlife that are specified as a representative receptor of ecological interest (RREI) are three species that are fossorial (i.e., burrowing) and one that is large, non-fossorial, and herbivorous. The three fossorial species are the California Ground Squirrel (Spermophilus beecheyi; home range 0.1 to 0.2 ha; see DFG, 2005a); the San Joaquin Kit Fox (Vulpes macrotis mutica; home range 2.6 to $5.2 \mathrm{~km}^{2}$; see DFG, 2005a) and the Burrowing Owl (Athene cunicularia; home range 0.4 to 1.6 ha; see DFG, 2005b). the large, non-fossorial, herbivorous organism is the Black-tailed Deer (Odocoileus hemionus columbianus; home range 1 to $3 \mathrm{~km}^{2}$; see DFG, 2005a).

Based on the emissions estimated from the OB / OD operations at the EWTF, and the TRVs for chemicals that actually are available in recommended regulatory guidance [e.g., see "Human and Ecological Risk Division (HERD) EcoNotes" provided by the State of California Department of Toxic Substances Control (DTSC, 2002a,b)] or that are reported and used in a recent ERA (e.g., the ecological risk assessment prepared for Toronto Public Health by Jacques Whitford Limited, 2004)], the CPECs identified as having biological significance for the specified RREIs are the heavy metals cadmium $(\mathrm{Cd})$, copper $(\mathrm{Cu})$, lead $(\mathrm{Pb})$, and zinc $(\mathrm{Zn})$, and six congeners of dioxins and furans (PCDDs/PCDFs). For each of the congeners, toxicity equivalency factors (TEFs) derived by the World Health Organization and adopted by the Cal/EPA (see Denton, 2003) are employed as a means for adjusting the predicted soil concentration of each congener to a level that would account for its toxicity relative to $2,3,7,8$ tetrachlorodibenzo-p-dioxin (TCDD). This simple mathematical adjustment permits individual exposure-pathway doses for all congeners for an RREI, or the total doses for all congeners from all relevant exposure pathways for an RREI, to be summed together to obtain the total dose for all emitted PCDDs/PCDFs, which can then be compared to a single TRV value for all PCDDs / PCDFs that typically reflects the toxicity of the most toxic congener (i.e., TCDD).

Table B-1 contains the maximum annual soil concentrations computed over both a 1-cm and a 15-cm depth for each CPEC emitted by the OB/OD operations associated with the EWTF at Site 300. Note that the concentrations estimated for lead appearing in Table B-1 represents $1 \%$ of the value actually predicted from the OBODM/HARP modeling. This adjustment is made because the lead that is emitted by OB/OD operations is considered to be overwhelmingly in a metallic or other chemical form that is not as readily bioavailable as lead acetate-the 
chemical form of lead that is highly bioavailable and that is used in laboratory toxicology studies that serve as the basis for the derivation of the low toxic reference value $\left(\mathrm{TRV}_{\text {Low }}\right.$; which is considered to represent a lowest credible no adverse effect level) for lead (see DTSC, 2000; 2002a,b).

Table B-1. Predicted maximum annual soil concentrations for each CPEC, obtained from OBODM/HARP atmospheric dispersion and deposition modeling and computed over both a $1-\mathrm{cm}$ and a $15-\mathrm{cm}$ depth, in the habitat near the OB/OD operations of the EWTF at Site 300.

\begin{tabular}{|c|c|c|}
\hline $\begin{array}{l}\text { Contaminant of } \\
\text { potential ecological } \\
\text { concern (CPEC) }\end{array}$ & $\begin{array}{l}\text { Maximum annual soil } \\
\text { concentration computed over } \\
\text { a 1-cm depth }\left(\mathrm{mg}_{\mathrm{CPEC}} / \mathrm{kg}_{\text {soil }}\right)\end{array}$ & $\begin{array}{l}\text { Maximum annual soil } \\
\text { concentration computed over } \\
\left.\text { a 15-cm depth ( } \mathrm{mg}_{\mathrm{CPEC}} / \mathrm{kg}_{\text {soil }}\right)\end{array}$ \\
\hline Cadmium (Cd) & $9.21 \times 10^{-1}$ & $6.14 \times 10^{-2}$ \\
\hline Copper (Cu) & $5.94 \times 10^{+2}$ & $3.96 \times 10^{+1}$ \\
\hline Lead $(\mathrm{Pb})^{\mathrm{a}}$ & $1.34 \times 10^{+0}$ & $8.93 \times 10^{-2}$ \\
\hline Zinc (Zn) & $1.60 \times 10^{+2}$ & $1.06 \times 10^{+1}$ \\
\hline $1,2,3,4,6,7,8-\mathrm{HpCDD}^{\mathrm{b}}$ & $2.17 \times 10^{-6}$ & $1.45 \times 10^{-7}$ \\
\hline $1,2,3,4,6,7,8-\mathrm{HpCDF}^{\mathrm{b}}$ & $3.60 \times 10^{-4}$ & $2.40 \times 10^{-5}$ \\
\hline $1,2,3,4,7,8,9-\mathrm{HpCDF}^{\mathrm{b}}$ & $8.34 \times 10^{-5}$ & $5.53 \times 10^{-6}$ \\
\hline $1,2,3,4,7,8-\mathrm{HxCDF}^{\mathrm{b}}$ & $2.22 \times 10^{-4}$ & $1.48 \times 10^{-5}$ \\
\hline $1,2,3,6,7,8-\mathrm{HxCDF}^{\mathrm{b}}$ & $1.01 \times 10^{-4}$ & $6.70 \times 10^{-6}$ \\
\hline $1,2,3,4,6,7,8,9-\mathrm{OCDF}^{\mathrm{b}}$ & $4.23 \times 10^{-4}$ & $2.82 \times 10^{-5}$ \\
\hline
\end{tabular}

a This soil concentration of lead is $1 \%$ of the value obtained from OBODM/HARP dispersion and deposition modeling and is considered to represent that amount of possible lead predicted over a specified depth depth in soil that may be bioavailable. The reason for this adjustment to the value computed using OBODM/HARP modeling is because the lead emitted from OB/OD operations is considered to be overwhelmingly in a metallic or other chemical form that is not as readily bioavailable as lead acetate-the chemical form of lead that is highly bioavailable and that is used in laboratory toxicology studies that serve

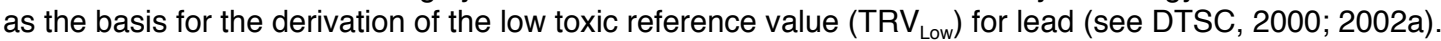

b This predicted soil concentration for the congener of polychlorinated-dibenzo-p-dioxins and dibenzofurans (PCDDs/PCDFs) considered to be a possible emission from OB/OD operations at the EWTF of Site 300 requires adjustment to account for its toxicity relative to $2,3,7,8-T C D D$ (see Table B-2).

Table B-2 contains the TEF-adjusted maximum annual soil concentrations computed over both a 1-cm and 15-cm depth for each potentially emitted individual congener of PCDDs/PCDFs, and the sums for all potentially emitted PCDDs / PCDFs for each soil concentration depth. It is these soil concentrations in Table B-2, which have been adjusted for relative toxicity (to TCDD) by the TEFs.

\section{Characteristics of Each RREI}

Each representative receptor of ecological interest (RREI) in the habitat near the OB/OD operations of the EWTF at Site 300 is presented in Table B-3, along with its expected values for relevant physiological and behavioral parameters of 
interest. On the basis of the limited amount of data available concerning these important physiological and behavioral parameters for each RREI at Site 300-body weight, fossorial behavior (i.e., time spent above and below ground by burrowing organisms), intake rate of air and food, diet, and incidental soil ingestion-only adult organisms are addressed. This collection of RREIs is considered to represent different levels of the ecological system, and any significant impact to one or more of these populations would, by inference, suggest the possibility of impacts to the entire ecosystem.

Table B-2. Toxic-equivalency-factor- (TEF-) adjusted maximum annual soil concentrations for each and all of the polychlorinated dibenzo-p-dioxins and dibenzofurans (PCDDs/PCDFs), predicted by OBODM/HARP atmospheric dispersion and deposition modeling in the habitat near OB/OD operations.

\begin{tabular}{|c|c|c|c|}
\hline $\begin{array}{l}\text { PCDD/PCDF } \\
\text { contaminants of } \\
\text { potential ecological } \\
\text { concern (CPECs) }\end{array}$ & $\begin{array}{l}\text { Toxic equivalency } \\
\text { factor (TEF) for } \\
\text { polychlorinated } \\
\text { dibenzo-p-dioxins } \\
\text { (PCDDs) and } \\
\text { dibenzofurans } \\
\text { (PCDFs) }^{\mathrm{a}}\end{array}$ & $\begin{array}{c}\text { TEF-adjusted } \\
\text { maximum annual } \\
\text { soil concentration } \\
\text { computed over a 1- } \\
\text { cm depth } \\
\left(\mathrm{mg}_{\mathrm{CPEC}} / \mathbf{k g}_{\text {soil }}\right)\end{array}$ & $\begin{array}{c}\text { TEF-adjusted } \\
\text { maximum annual } \\
\text { soil concentration } \\
\text { computed over a 15- } \\
\text { cm depth } \\
\left(\mathbf{m g}_{\text {CPEd }} / \mathbf{k g}_{\text {soil }}\right)\end{array}$ \\
\hline $1,2,3,4,6,7,8-\mathrm{HpCDD}$ & 0.01 & $2.17 \times 10^{-8}$ & $1.45 \times 10^{-9}$ \\
\hline 1,2,3,4,6,7,8-HpCDF & 0.01 & $3.60 \times 10^{-6}$ & $2.40 \times 10^{-7}$ \\
\hline $1,2,3,4,7,8,9-\mathrm{HpCDF}$ & 0.01 & $8.34 \times 10^{-7}$ & $5.53 \times 10^{-8}$ \\
\hline $1,2,3,4,7,8-\mathrm{H} \times \mathrm{CDF}$ & 0.10 & $2.22 \times 10^{-5}$ & $1.48 \times 10^{-6}$ \\
\hline $1,2,3,6,7,8-\mathrm{HxCDF}$ & 0.10 & $1.01 \times 10^{-5}$ & $6.70 \times 10^{-7}$ \\
\hline $1,2,3,4,6,7,8,9-\mathrm{OCDF}$ & 0.0001 & $4.23 \times 10^{-8}$ & $2.82 \times 10^{-9}$ \\
\hline \multicolumn{2}{|c|}{ Total for TEF-adjusted PCDDs/PCDFs ${ }^{\mathrm{b}}=$} & $3.68 \times 10^{-5}$ & $2.45 \times 10^{-6}$ \\
\hline
\end{tabular}

a Multipliers by which respective soil concentrations from Table B-1 for polychlorinated dibenzo-p-dioxins and dibenzofurans (PCDDs/PCDFs) predicted from OBODM/HARP atmospheric dispersion and deposition modeling and computed over a specified depth are adjusted relative to the toxicity of 2,3,7,8-TCDD, which is considered to have a toxic equivalency factor (TEF) equal to 1.0.

b Sum of congener-specific TEF-adjusted values of soil concentration computed over a specified depth, and representing the total for all PCDDs/PCDFs potentially emitted from OB/OD operations at the EWTF. 
Table B-3. Expected values for the physiological and behavioral characteristics of each adult representative receptor of ecological interest (RREI) near OB/OD operations. $^{\text {a }}$

\begin{tabular}{|c|c|c|c|c|c|c|}
\hline $\begin{array}{l}\text { Adult representative } \\
\text { receptor of } \\
\text { ecological interest } \\
\text { (RREI) }\end{array}$ & $\begin{array}{l}\text { Body } \\
\text { weight } \\
\text { (kg) }\end{array}$ & $\begin{array}{l}\text { Inhala- } \\
\text { tion } \\
\text { rate } \\
\left(\mathrm{m}^{3} / \mathrm{d}\right)\end{array}$ & $\begin{array}{l}\text { Total } \\
\text { food-intake } \\
\text { rate }\left(\mathbf{k g}_{\text {wet }} / \mathbf{d}\right) \\
\text { and diet } \\
\text { (assumed } \\
\text { percentage) }\end{array}$ & $\begin{array}{l}\text { Incidental } \\
\text { soil- } \\
\text { ingestion } \\
\text { fraction of } \\
\text { total food- } \\
\text { intake rate }\end{array}$ & $\begin{array}{l}\text { Fraction } \\
\text { of time } \\
\text { spent } \\
\text { above } \\
\text { ground at } \\
\text { surface }^{b}\end{array}$ & $\begin{array}{l}\text { Fraction of } \\
\text { time spent } \\
\text { under } \\
\text { ground } \\
\text { in burrow }\end{array}$ \\
\hline $\begin{array}{l}\text { California Ground } \\
\text { Squirrel } \\
\text { (Spermophilus }^{\text {(Seecheyi) }}{ }^{\text {d }}\end{array}$ & 0.56 & 0.27 & $\begin{array}{l}0.042 ; \\
\text { vegetation } \\
(100 \%)\end{array}$ & 0.077 & 0.20 & 0.80 \\
\hline $\begin{array}{l}\text { Black-tailed Deer } \\
\text { (Odocoileus } \\
\text { hemionus } \\
\text { columbianus) }\end{array}$ & 60 & 21.6 & $\begin{array}{l}1.61 ; \\
\text { vegetation } \\
(100 \%)\end{array}$ & 0.020 & 1.0 & $\begin{array}{l}\text { Not } \\
\text { applicable }\end{array}$ \\
\hline $\begin{array}{l}\text { San Joaquin Kit Fox } \\
\text { (Vulpes macrotis } \\
\text { mutica })^{\mathrm{d}}\end{array}$ & 2.15 & 1.5 & $\begin{array}{l}0.175 ; \\
\text { ground squirrel } \\
(100 \%)\end{array}$ & 0.028 & 0.50 & 0.50 \\
\hline $\begin{array}{l}\text { Burrowing Owl } \\
\text { (Athene cunicularia) }^{\mathrm{e}}\end{array}$ & 0.157 & 0.176 & $\begin{array}{l}0.026 ; \\
\text { ground squirrel } \\
(50 \%)\end{array}$ & 0.050 & 0.70 & 0.30 \\
\hline
\end{tabular}

a Water ingestion rate is not provided because waters are not generally present at location of maximum exposure.

b Above-ground, mass-loading factor is the site-specific total suspended particulate value reported and used by Carlsen (1996) to obtain the breathing concentration for resuspended contaminated soil particulates that could be inhaled by wildlife during time spent above ground at Site 300 [i.e., concentration of contaminated particles in above-ground air $\left(\mathrm{mg}_{\mathrm{CPEC}} / \mathrm{m}^{3}\right)$ is the product of the soil concentration $\left(\mathrm{mg}_{\mathrm{CPEC}} / \mathrm{kg}_{\text {soil }}\right.$ over a $1-\mathrm{cm}$ depth) and the site-specific mass-loading factor $\left(2.3 \times 10^{-8}\right.$ $\left.\left.\mathrm{kg}_{\text {soil }} / \mathrm{m}^{3}\right)\right]$.

c Underground, mass-loading factor is the assumed total suspended particulate value reported and used by Carlsen (1996) to obtain the breathing concentration for resuspended contaminated soil particles that could be inhaled by wildlife during time spent under ground in burrows at Site 300 [i.e., concentration of contaminated particles in burrow air $\left(\mathrm{mg}_{\mathrm{CPEC}} / \mathrm{m}^{3}\right)$ is the product of the soil concentration $\left(\mathrm{mg}_{\mathrm{CPEC}} / \mathrm{kg}_{\text {soil }}\right.$ over a 15-cm depth) and the assumed underground mass-loading factor $\left.\left(1.0 \times 10^{-7} \mathrm{~kg}_{\mathrm{soi}} / \mathrm{m}^{3}\right)\right]$.

d Data are reported and used by Carlsen (1996) for this wildlife at Site 300.

e Body weight determined from data presented by (Thomsen, 1971); inhalation rate is from data cited by Sample et al. (1997); total food intake rate [assumed for Site 300 to be represented by a diet of $50 \%$ squirrel meat and $50 \%$ insects, based on observational data noted by Biermann et al. (2001) indicating squirrels are eaten half of the year and insects half of the year]; incidental soil-ingestion fraction of total food-intake rate estimated from data presented by Thomsen (1971) and Zarn (1973); and fraction of time spent above ground and below ground interpreted from daily movements reported by Thomsen (1971).

\section{Estimated Total Daily Dose for Each RREI}

The estimated total daily dose, $\mathrm{D}_{\text {total, }}$ of a CPEC for an adult RREI is obtained as the sum of the doses for the CPEC that can be acquired by the inhalation, incidental soil-ingestion, and food-ingestion exposure pathways (see Eq. 1). It is 
this CPEC-specific total dose that is used in combination with a body-weight scaled, a CPEC-specific toxic reference value (TRV) to derive a CPEC-specific ecological hazard quotient (EHQ). As will be explained, the EHQ is the figure of merit for determining whether there is a potential for adverse effects for the adult RREIs, and by inference to the RREI population and ecological system, from the exposures to the particular CPEC.

$$
\mathrm{D}_{\text {total }}=\mathrm{D}_{\text {air }}+\mathrm{D}_{\text {soil }}+\mathrm{D}_{\text {food, }} \text { where }
$$

$D_{\text {total }}=$ Potential total daily dose of a CPEC for an adult RREI from all exposure pathways $[\mathrm{mg} /(\mathrm{kg} \cdot \mathrm{d})]$;

$\mathrm{D}_{\text {air }}=$ Potential daily dose of a CPEC acquired by an adult RREI from inhalation exposure of contaminated soil particles resuspended into the air $[\mathrm{mg} /(\mathrm{kg} \cdot \mathrm{d})]$;

$\mathrm{D}_{\text {soil }}=$ Potential daily dose of a CPEC acquired by an adult RREI from incidental ingestion of contaminated soil $[\mathrm{mg} /(\mathrm{kg} \cdot \mathrm{d})]$; and

$\mathrm{D}_{\text {food }}=$ Potential daily dose of a CPEC acquired by an adult RREI from dietary intake of contaminated food (e.g., vegetation or prey) $[\mathrm{mg} /(\mathrm{kg} \cdot \mathrm{d})]$.

\section{Inhalation-Exposure Dose}

The inhalation dose, $\mathrm{D}_{\text {air }}$ of each CPEC for each RREI occurs as a consequence of resuspension of contaminated soil particles into the breathing air. This inhalation dose is calculated according to Eq. 2.

$$
\mathrm{D}_{\text {air }}=\mathrm{C}_{\text {air }} \times \mathrm{IR}_{\text {RREI }} \times\left(1 / \mathrm{BW}_{\text {RREI }}\right) \text {, where }
$$

$\mathrm{D}_{\text {air }} \quad=$ Potential daily inhalation dose of CPEC for an adult RREI from contaminated soil particles resuspended into air $[\mathrm{mg} /(\mathrm{kg} \cdot \mathrm{d})]$;

$\mathrm{C}_{\text {air }} \quad=$ Weighted average concentration of CPEC in breathing air $\left(\mathrm{mg} / \mathrm{m}^{3}\right)$; derived as sum of the products of the fraction of time spent at surface or in burrow; the corresponding maximum annual soil concentration [at surface (use concentration over 1-cm depth) or in burrow (use concentration over 15-cm depth)] for a CPEC $\left(\mathrm{mg}_{\mathrm{CPEC}} / \mathrm{kg}_{\text {soil }}\right)$, and the respective mass-loading factor [i.e., above $\left(2.3 \times 10^{-8} \mathrm{~kg}_{\text {soil }} / \mathrm{m}^{3}\right)$ or below $\left(1.0 \times 10^{-7} \mathrm{~kg}_{\text {soil }} / \mathrm{m}^{3}\right)$ ground]; and

$\mathrm{IR}_{\text {RREI }}=$ Inhalation rate of air for adult RREI $\left(\mathrm{m}^{3} / \mathrm{d}\right)$; and

$\mathrm{BW}_{\text {RREI }}=$ Body weight for adult RREI (kg).

\section{Incidental Soil-Ingestion Exposure Dose}

The incidental soil-ingestion dose, $\mathrm{D}_{\text {soil }}$, for each adult RREI that is acquired from the CPEC concentration predicted to be in soil is determined using Eq. 3.

$$
\mathrm{D}_{\text {soil }}=\mathrm{C}_{\text {soil }} \times\left(\mathrm{FIR}_{\text {RREI }} \times \mathrm{SFD}_{\text {RREI }}\right) \times\left(1 / \mathrm{BW}_{\text {RREI }}\right) \text {, where }
$$



$\mathrm{D}_{\text {soil }} \quad=$ Potential daily dose of CPEC for an adult RREI from incidental ingestion of contaminated soil particles $[\mathrm{mg} /(\mathrm{kg} \cdot \mathrm{d})]$;
$\mathrm{C}_{\text {soil }}=$ Maximum annual soil concentration of CPEC in soil computed over a 15-cm depth, which is obtained from OBODM/HARP atmospheric dispersion and deposition modeling $\left(\mathrm{mg}_{\mathrm{CPEC}} / \mathrm{kg}_{\mathrm{Soil}}\right)$;
$\mathrm{FIR}_{\text {RREI }}=$ Total food-intake rate for an adult RREI $(\mathrm{kg} / \mathrm{d})$;
$\mathrm{SFD}_{\mathrm{RREI}}=$ Adult RREI-specific soil-ingestion fraction of total food-intake rate (dimensionless); and
$\mathrm{BW}_{\text {RREI }}=$ Body weight for adult RREI (kg).

\section{Food-Ingestion Exposure Dose}

Four equations are used to determine the food-ingestion dose, $\mathrm{D}_{\text {food }}$, for each adult RREI. For the ground squirrel and deer, which are considered herbivorous consumers at Site 300 (based on Carlsen, 1996), the uptake of CPEC into the vegetation is calculated using either Eq. 4 (for the congeners of PCDDs/PCDFs) or Eq. 5 (for the heavy metals). For the Kit Fox, where the ground squirrel is assumed to represent 100\% of its diet (see Table B-3), and for the Burrowing Owl, where the ground squirrel is considered to represent $50 \%$ of its diet and insects (considered not to be contaminated in ingestion calculations) constitute the remaining $50 \%$ of its diet [according to observational data reported in Biermann et al. (2001); see Table B-3], the uptake factors for a CPEC into the ground squirrel are computed using Eq. 6 . The respective CPEC-uptake factors for vegetation or for the ground squirrel are then used in Eq. 7, which yields the dose from the contaminated food consumed by a specific RREI.

The uptake factor for all PCDDs / PCDFs from soil into vegetation is derived for the applicable RREIs using Eq. 4. This calculation yields a result of 0.00107 and is based on the method of Travis and Arms (1988), and was implemented by Jacques Whitford Limited (2004) in an ecological risk assessment prepared for Toronto (Canada) Public Health.

$$
\begin{aligned}
\mathrm{UF}_{\mathrm{DFveg}}= & \mathrm{BAF}_{\mathrm{DFveg}} \times \mathrm{DWCF}_{\text {veg }} \text { [see Jacques and } \\
& \text { Whitford Limited (2004; Table 7-3)], where }
\end{aligned}
$$

$\mathrm{UF}_{\mathrm{DFveg}}=\mathrm{PCDD} / \mathrm{PCDF}(\mathrm{DF})$ uptake factor from soil to vegetation $\left(\mathrm{mg}_{\mathrm{DF}} / \mathrm{kg}_{\text {veg fresh-wt }}\right.$ per $\left.\mathrm{mg}_{\mathrm{DF}} / \mathrm{kg}_{\text {soil }}\right)$;

$\mathrm{BAF}_{\mathrm{DFveg}}=\mathrm{PCDD} / \mathrm{PCDF}(\mathrm{DF})$ bioaccumulation factor for plant tissue [0.0056 $\mathrm{kg}_{\mathrm{DF}} / \mathrm{kg}_{\text {veg dry-wt; }}$; see Jacques and Whitford (2004; pp. 71 and 127, and Table 7-3); as derived from Travis and Arms (1988)]; and

$\mathrm{DWCF}_{\mathrm{veg}} \quad=$ Dry-to-Wet weight conversion factor for vegetation $\left[0.19 \mathrm{~kg}_{\text {veg dry-wt }} / \mathrm{kg}_{\text {veg fresh-wt }}\right.$ adopted from USEPA (1993) by Jacques Whitford Limited (2004; footnotes to Table 7-3)]. 
The uptake factors for the heavy-metal CPECs from soil into vegetation are derived for the applicable RREIs using Eq. 5 and the CPEC-specific regression factors appear in Table B-4, along with the uptake factors. This calculation and the data appearing in Table B-4 are consistent with the simple regression equation describing bioaccumulation in vegetation relative to soil concentrations that was developed by Efroymson et al. (2001) and implemented by Jacques Whitford Limited (2004) in an ecological risk assessment prepared for Toronto (Canada) Public Health.

$$
\begin{aligned}
& \mathrm{UF}_{\text {HMveg }}=\left[\mathrm{EXP}\left\{\mathrm{B}_{0-\mathrm{HMveg}}+\left[\mathrm{B}_{1-\mathrm{HMveg}} \times \operatorname{Ln}\left(\mathrm{C}_{\text {soil-HM }}\right)\right]\right\} / \mathrm{C}_{\text {soil-HM }}\right] \times \mathrm{DWCF}_{\text {veg }} \\
& \mathrm{UF}_{\mathrm{HMveg}}=\text { Heavy metal }(\mathrm{HM}) \text { uptake factor from soil to vegetation } \\
& \left(\mathrm{mg}_{\mathrm{HM}} / \mathrm{kg}_{\text {veg fresh-wt }} \text { per } \mathrm{mg}_{\mathrm{HM}} / \mathrm{kg}_{\text {soil }}\right) \text {; } \\
& \mathrm{B}_{0-\mathrm{HMveg}} \\
& \text { and } \mathrm{B}_{1-\mathrm{HMveg}} \quad=\text { Heavy metal }(\mathrm{HM}) \text { specific regression coefficients }\left(\mathrm{B}_{0} \text { and } \mathrm{B}_{1}\right) \\
& \text { applicable to heavy metals bioaccumulation in vegetation [see } \\
& \text { Jacques Whitford Limited (2004; Tables 5-22 and 7-3)]; } \\
& \mathrm{C}_{\text {soil-HM }} \\
& =\text { Maximum annual soil concentration of specific heavy metal } \\
& \text { (HM) predicted by OBODM/HARP atmospheric dispersion } \\
& \text { and deposition modeling and computed over a 15-cm depth } \\
& \left(\mathrm{mg}_{\mathrm{HM}} / \mathrm{kg}_{\text {soil }}\right) \text {; and } \\
& \mathrm{DWCF}_{\mathrm{veg}} \quad=\text { Dry-to-Wet weight conversion factor for vegetation } \\
& \text { [0.19 } \mathrm{kg}_{\text {veg dry-wt }} / \mathrm{kg}_{\text {veg fresh-wt }} \text { as adopted from USEPA (1993) and } \\
& \text { used by Jacques Whitford Limited (2004; footnotes to } \\
& \text { Table 7-3)]. }
\end{aligned}
$$


The uptake factors for all CPECs (i.e., the heavy metals and PCDDs/PCDFs) for small mammals, such as a California Ground Squirrel, relative to the predicted soil concentrations are derived for each applicable RREI using Eq. 6, and the CPEC-specific regression factors appear in Table B-5, along with the uptake

Table B-5. Regression coefficients used in Eq. 6 for predicting uptake into a small mammal (e.g., California Ground Squirrel) of each CPEC, relative to its soil concentration over a 15-cm depth.

\begin{tabular}{|c|c|c|c|}
\hline \multirow{2}{*}{$\begin{array}{l}\text { Contaminant of potential } \\
\text { ecological concern (CPEC) }\end{array}$} & \multicolumn{2}{|c|}{ Regression coefficients ${ }^{b}$} & \multirow{2}{*}{$\begin{array}{l}\text { Best estimate of uptake } \\
\text { factor predicted for } \\
\text { contaminant in small } \\
\text { mammal (UF } \text { CPECsm; }_{\text {; }} \\
\left.\mathrm{mg} / \mathrm{kg}_{\text {animal wet }} \text { per } \mathrm{mg} / \mathrm{kg}_{\text {soil }}\right)\end{array}$} \\
\hline & $\mathrm{B}_{0-\mathrm{CPEC} s \mathrm{~m}}$ & $\mathrm{~B}_{\text {1-CPECsm }}$ & \\
\hline Cadmium (Cd) & 0.431 & 0.487 & $0.871^{\mathrm{c}}$ \\
\hline Copper $(\mathrm{Cu})$ & 2.042 & 0.144 & 0.106 \\
\hline Lead $(\mathrm{Pb})$ & 0.076 & 0.442 & 1.329 \\
\hline Zinc $(Z n)$ & 4.471 & 0.074 & 3.142 \\
\hline PCDDs/PCDFs ${ }^{d}$ & 0.8113 & 1.099 & \\
\hline 1,2,3,4,6,7,8-HpCDD & & & 0.096 \\
\hline $1,2,3,4,6,7,8-\mathrm{HpCDF}$ & & & 0.159 \\
\hline $1,2,3,4,7,8,9-\mathrm{HpCDF}$ & & & 0.138 \\
\hline $1,2,3,4,7,8-\mathrm{H} \times \mathrm{CDF}$ & & & 0.191 \\
\hline $1,2,3,6,7,8-\mathrm{HxCDF}$ & & & 0.176 \\
\hline $1,2,3,4,6,7,8,9-\mathrm{OCDF}$ & & & 0.103 \\
\hline
\end{tabular}

a See Table B-1 for maximum annual soil concentrations over $15-\mathrm{cm}$ for heavy metals ( $\mathrm{Cd}, \mathrm{Cu}, \mathrm{Pb}$, and $\mathrm{Zn}$ ) and Table B-2 for maximum annual soil concentrations over 15-cm for TEF-adjusted polychlorinated dibenzo-p-dioxins and dibenzofurans (PCDDs/PCDFs).

b Regression coefficients are used in simple regression equation developed by Sample et al. (1998) and are reported and implemented by Jacques Whitford Limited (2004; see Table 7-3) in an ecological risk assessment prepared for Toronto (Canada) Public Health.

c Predicted uptake factor for $\mathrm{Cd}$ is consistent with an expected range of values of 0.29 to 0.44 for the biotransfer factor from soil to tissue for ground squirrels at Site 300 (based on olfactory bulb uptake analyses performed and reported by Bench et al., 2001; see Tables 3 and 4).

d Regression coefficients are applicable to all congeners, and the sum of the products of maximum annual soil concentrations of TEF-adjusted polychlorinated dibenzo-p-dioxins and dibenzofurans (PCDDs/PCDFs) over a 15-cm depth and respective uptake factors yields the best estimate of the small mammal whole body concentration $(\mathrm{mg} / \mathrm{kg})$ for all PCDDs/PCDFs.

factors. Although similar to Eq. 5, which is applicable to bioaccumulation of heavy metals in vegetation, Eq. 6 addresses bioaccumulation in the squirrel relative to the predicted soil concentration. This simple regression equation and its coefficients are from Sample et al. (1998) and also were implemented by 
Jacques Whitford Limited (2004) in an ecological risk assessment prepared for Toronto (Canada) Public Health.

$$
\begin{aligned}
& \left.\mathrm{UF}_{\mathrm{CPECSm}}=\left[\mathrm{EXP}\left\{\mathrm{B}_{0 \text {-CPECsm }}+\left[\mathrm{B}_{1-\mathrm{CPECSm}} \times \mathrm{Ln}\left(\mathrm{C}_{\text {soil-CPEC }}\right)\right]\right)\right\} / \mathrm{C}_{\text {soil-CPEC }}\right] \times \mathrm{DWCF}_{\text {sm }}(6) \\
& \text { [see Jacques and Whitford Limited (2004; Table 7-3)], where } \\
& \mathrm{UF}_{\mathrm{CPECsm}}=\text { Uptake factor for bioaccumulation of a contaminant of } \\
& \text { potential ecological concern (CPEC) in a small mammal (sm) } \\
& \text { relative to the soil concentration }\left(\mathrm{mg}_{\mathrm{CPEC}} / \mathrm{kg}_{\text {sm fresh-wt }}\right. \text { per } \\
& \left.\mathrm{mg}_{\mathrm{CPEC}} / \mathrm{kg}_{\text {soil }}\right) \text {; } \\
& \mathrm{B}_{0-\mathrm{CPECSm}} \\
& \text { and } \mathrm{B}_{1-\mathrm{CPEC} S \mathrm{~m}}=\text { Specific regression coefficients }\left(\mathrm{B}_{0} \text { and } \mathrm{B}_{1}\right) \text { for bioaccumulation } \\
& \text { of a CPEC in a small mammal [see Jacques Whitford Limited } \\
& \text { (2004; Table 7-3]; and. } \\
& \mathrm{C}_{\text {soil-CPEC }}=\text { Maximum annual soil concentration for a CPEC predicted by } \\
& \text { OBODM/HARP atmospheric dispersion and deposition } \\
& \text { modeling and computed over a 15-cm depth }\left(\mathrm{mg}_{\mathrm{HM}} / \mathrm{kg}_{\text {soil }}\right) \text {; } \\
& \text { and } \\
& \mathrm{DWCF}_{\mathrm{sm}} \quad=\text { Dry-to-Wet weight conversion factor for a small mammal } \\
& {\left[0.32 \mathrm{~kg}_{\text {sm dry-wt }} / \mathrm{kg}_{\text {sm fresh-wt }}\right. \text { as adopted from Sample et al. (1998) }} \\
& \text { and used by Jacques Whitford Limited (2004; footnotes to } \\
& \text { Table 7-3)]. }
\end{aligned}
$$

The estimated food-ingestion doses for the respective RREIs are then obtained using Eq. 7.

$$
\mathrm{D}_{\text {food }}=\mathrm{C}_{\text {soil }} \times \mathrm{UF}_{\mathrm{CPECi}} \times \mathrm{FIR}_{\mathrm{i}} \times\left(1 / \mathrm{BW}_{\mathrm{RREI}}\right) \times \text {, where }
$$

$\mathrm{D}_{\text {food }} \quad=$ Daily dose of contaminant of potential ecological concern (CPEC) for an adult RREI from ingestion of contaminated food $[\mathrm{mg} /(\mathrm{kg} \cdot \mathrm{d})]$

$\mathrm{C}_{\text {soil }}=$ Maximum annual soil concentration for a CPEC predicted by OBODM/HARP atmospheric dispersion and deposition modeling and computed over a 15-cm depth $\left(\mathrm{mg}_{\mathrm{HM}} / \mathrm{kg}_{\text {soi }}\right)$;

$\mathrm{UF}_{\mathrm{CPECi}}=$ Uptake factor for contaminant of potential ecological concern (CPEC) in food group, i (i.e., vegetation or small mammal), relative to concentration in soil $\left(\mathrm{mg}_{\mathrm{CPEC}} / \mathrm{kg}_{\text {i fresh-wt }}\right.$ per $\left.\mathrm{mg}_{\mathrm{CPEC}} / \mathrm{kg}_{\text {soil }}\right)$.

FIR $_{\mathrm{i}}=$ Food intake rate (i.e., product of assumed contaminated food-intake rate and the dietary percentage) of food, i (i.e., vegetation or small mammal), for an adult RREI $\left(\mathrm{kg}_{\text {ifresh-wt }} / \mathrm{d}\right)$; and

$\mathrm{BW}_{\text {RREI }}=$ Body weight for adult RREI $(\mathrm{kg})$.

In summary, for the squirrel and deer, which are considered herbivorous consumers in the habitat near the OB/OD operations conducted at the EWTF of Site 300, either Eq. 4 (applicable to PCDDs/ PCDFs) or Eq. 5 (applicable to heavy metals) is used to determine the applicable uptake factor for the respective CPEC 
$\left(\mathrm{UF}_{\text {CPECveg; }} ; \mathrm{mg}_{\mathrm{CPEC} \text { veg }} / \mathrm{kg}_{\text {veg fresh-wt }}\right.$ per $\left.\mathrm{mg}_{\text {CPEC }} / \mathrm{kg}_{\text {soil }}\right)$ for insertion in Eq. 7, which is then used to derive $\mathrm{D}_{\text {food }}$ for these organisms. However, for the Kit Fox and Burrowing Owl, which are considered small-mammal carnivores in this same vicinity, Eq. 6 is used to determine the applicable uptake factor $\left(\mathrm{UF}_{\mathrm{CPECsm}}\right.$; $\mathrm{mg}_{\text {CPEC }} / \mathrm{kg}_{\text {sm fresh-wt }}$ per $\left.\mathrm{mg}_{\text {CPEC }} / \mathrm{kg}_{\text {soil }}\right)$ for insertion in Eq. 7 , which is then used to derive $D_{\text {food }}$ for these organisms.

\section{Ecological Hazard Quotient (EHQ) for Each CPEC and RREI}

The CPEC-specific ecological hazard quotients for each RREI (EHQ $\left.{ }_{\text {CPEC-RREI }}\right)$ are obtained using Eq. 8:

$$
\mathrm{EHQ}_{\text {CPEC-RREI }}=\mathrm{D}_{\text {total }} / \mathrm{TRV}_{\mathrm{CPEC-RREI}} \text {; where }
$$

$\mathrm{EHQ}_{\text {CPEC-RREI }}=\begin{aligned} & \text { Ecological hazard quotient for a CPEC and an RREI } \\ & \text { (dimensionless); }\end{aligned}$

$\mathrm{D}_{\text {total }} \quad=$ Potential total daily dose of a CPEC for an adult RREI from all exposure pathways considered relevant $[\mathrm{mg} /(\mathrm{kg} \cdot \mathrm{d})]$; and

$\mathrm{TRV}_{\text {CPEC-RREI }}=$ Applicable toxicity reference value (TRV) for an RREI; according to DTSC $(2002 a, b)$, either a TRV $\mathrm{Low}_{\text {, }}$ which represents a credible lowest no adverse effect level, is applied; and then a $\mathrm{TRV}_{\text {High, }}$ which represents the mid-point of the threshold for a variety of adverse effects, may also be applied $[\mathrm{mg} /(\mathrm{kg} \cdot \mathrm{d})]$ (see text for explanation).

Because the toxicity reference values (TRVs) for CPECs were not available for the specific mammalian and avian RREIs of interest, a scaling factor based on body weight is applied to convert the TRV obtained from an experimental test species (ETS), considered similar to a particular RREI, to one considered more directly applicable to the respective wildlife RREI. This approach is based on the procedure of Sample and Arenal (1999) that is described and implemented by Jacques Whitford Limited (2004) in an ecological risk assessment prepared for Toronto (Canada) Public Health. The calculation for transforming a TRV for an experimental test species to the TRV applicable to the respective wildlife RREI appears in Eq. 9.

$$
\mathrm{TRV}_{\text {CPEC-RREI }}=\mathrm{TRV}_{\text {CPEC-ETS }} \times\left(\mathrm{BW}_{\mathrm{ETS}} / \mathrm{BW}_{\mathrm{RREI}}\right)^{1-\mathrm{b}} ;
$$

$$
\begin{aligned}
& \mathrm{TRV}_{\text {CPEC-RREI }}=\text { Toxicity reference value (TRV) for a CPEC and an RREI } \\
& {[\mathrm{mg} /(\mathrm{kg} \cdot \mathrm{d})]} \\
& \mathrm{TRV}_{\mathrm{CPEC}-\mathrm{ETS}}=\text { Toxicity reference value (TRV) for CPEC and experimental test } \\
& \text { BW }_{\mathrm{ETS}} \quad=\text { Body weight for ETS }(\mathrm{kg} \text {; see Table B-6); } \\
& \mathrm{BW}_{\text {RREI }} \quad=\text { Body weight of respective RREI (kg; see Table B-3); } \\
& \mathrm{b} \quad=\text { Allometric scaling factor (dimensionless; see Table B-6) from } \\
& \text { Sample and Arenal (1999) reported and implemented by }
\end{aligned}
$$


Jacques Whitford Limited (2004) in an ecological risk assessment prepared for Toronto (Canada) Public Health.

Table B-6. Contaminant of potential ecological concern (CPEC), high and low toxic reference values $\left(T R V_{\text {Low }} s\right.$ and $\left.T R V_{\text {High }} s\right)$ for experimental test species (ETS), and factors needed to scale by body weight a specific TRV $\mathrm{TPEC}_{\mathrm{CETS}}$ to one applicable to the RREI using Eq. 9. ${ }^{\text {a }}$

\begin{tabular}{|c|c|c|c|c|}
\hline $\begin{array}{l}\text { Contaminant of } \\
\text { potential } \\
\text { ecological } \\
\text { concern (CPEC) }\end{array}$ & $\begin{array}{l}\text { Experimental test species } \\
\text { (ETS) corresponding to } \\
\text { TRV }_{\text {Low }} \text { and } T \mathrm{RV}_{\text {High }} \text { values }\end{array}$ & $\begin{array}{l}\text { Values for low } \\
\text { and high } \\
\mathrm{TRV}_{\mathrm{CPEC}-\mathrm{ETS}} \\
(\mathrm{mg} / \mathrm{kg} \cdot \mathrm{d})\end{array}$ & $\begin{array}{c}\text { ETS } \\
\text { body } \\
\text { weight } \\
\text { (kg) }\end{array}$ & $\begin{array}{l}\text { Allometric } \\
\text { scaling } \\
\text { factor }\end{array}$ \\
\hline Cadmium (Cd) & $\begin{array}{l}\text { Mammal: } \\
\operatorname{TRV}_{\text {Low }}=\text { Mouse } \\
\operatorname{TRV}_{\text {High }}=\text { Mouse } \\
\text { Avian: } \\
\text { TRV }_{\text {Low }}=\text { Mallard duck } \\
\operatorname{TRV}_{\text {High }}=\text { Mallard duck }\end{array}$ & $\begin{array}{l}0.06 \\
2.64 \\
\\
0.08 \\
10.4\end{array}$ & $\begin{array}{l}0.03 \\
0.03 \\
\\
1.153 \\
1.153\end{array}$ & $\begin{array}{l}0.44 \\
0.44 \\
1.2 \\
1.2\end{array}$ \\
\hline Copper $(\mathrm{Cu})$ & $\begin{array}{l}\text { Mammal: } \\
\operatorname{TRV}_{\text {Low }}=\text { Mouse } \\
\operatorname{TRV}_{\text {High }}=\text { Mouse } \\
\text { Avian: } \\
\operatorname{TRV}_{\text {Low }}=\text { Chicken } \\
\operatorname{TRV}_{\text {High }}=\text { Chicken }\end{array}$ & $\begin{array}{r}2.67 \\
632 \\
\\
2.3 \\
52.3\end{array}$ & $\begin{array}{l}0.03 \\
0.03 \\
\\
1.5 \\
1.5\end{array}$ & $\begin{array}{l}0.94 \\
0.94 \\
1.2 \\
1.2\end{array}$ \\
\hline Lead $(\mathrm{Pb})$ & $\begin{array}{l}\text { Mammal: } \\
\operatorname{TRV}_{\text {Low }}=\text { Rat } \\
\operatorname{TRV}_{\text {High }}=\text { Mouse } \\
\text { Avian: } \\
\operatorname{TRV}_{\text {Low }}=\text { Quail } \\
\operatorname{TRV}_{\text {High }}=\text { Chicken }\end{array}$ & $\begin{array}{l}1 \\
241 \\
\\
0.014 \\
8.75\end{array}$ & $\begin{array}{l}0.35 \\
0.03 \\
\\
0.15 \\
1.5\end{array}$ & $\begin{array}{l}0.94 \\
0.94 \\
1.2 \\
1.2\end{array}$ \\
\hline$\overline{Z i n c}(Z n)$ & $\begin{array}{l}\text { Mammal: } \\
\operatorname{TRV}_{\text {Low }}=\text { Mouse } \\
\operatorname{TRV}_{\text {High }}=\text { Mouse } \\
\text { Avian: } \\
\text { TRV }_{\text {Low }}=\text { Mallard duck } \\
\operatorname{TRV}_{\text {High }}=\text { Mallard duck }\end{array}$ & $\begin{array}{c}17.2 \\
172\end{array}$ & $\begin{array}{l}1.153 \\
1.153\end{array}$ & $\begin{array}{l}0.94 \\
1.2 \\
1.2\end{array}$ \\
\hline PCDDs/PCDFs & $\begin{array}{ll}\text { Mammal: } & \\
\text { TRV }_{\text {Low }}= & \text { Rat } \\
\text { Avian: } & \\
\text { TRV }_{\text {Low }}= & \begin{array}{l}\text { Ring Necked } \\
\text { Pheasant }\end{array}\end{array}$ & $\begin{array}{l}0.00001 \\
0.00014\end{array}$ & $\begin{array}{l}0.35 \\
1\end{array}$ & $\begin{array}{l}0.537 \\
1.2\end{array}$ \\
\hline
\end{tabular}

a See DTSC (2002b) for high and low TRVs, except for PCDDs/PCDFs; see DTSC (2000, 2002a) comment on lead bioavailability in Table B-1, footnote a; and see the ecological risk assessment prepared for Toronto (Canada) Public Health by Jacques Whitford Limited (2004; Tables 7-5 and 7-6) for the TRV data considered applicable to PCDDs/PCDFs and for the ETS body weight, and allometric scaling factor values (taken from Sample and Arenal, 1999). 
The TRVs (both highs and lows) that are applicable to heavy metals are those recommended by the Biological and Technical Assistance Group (BTAG) and are based on data from experimental test mammals and birds. These TRVs for the heavy metals are available from DTSC $(2002 a, b)$. The $\operatorname{TRV}_{\text {Low }}$ is considered to represent a credible lowest no adverse effect level, and the $\mathrm{TRV}_{\mathrm{High}}$ is considered to represent the mid-point of the threshold for a variety of adverse effects (DTSC, 2002a,b). For the PCDDs/ PCDFs, a TRV was selected from a recent ecological risk assessment prepared for Toronto (Canada) Public Health by Jacques Whitford Limited (2004). The high and low TRV values for the metals are obtained from DTSC $(2002 a, b)$. The TRV for the PCDDs/PCDFs is considered representative of a TRV $\mathrm{Low}_{\text {Lo }}$. The TRVs for the heavy metals and PCDDs/PCDFs obtained from the literature, the species tested experimentally, the body weights for the species tested experimentally, and the allometric scaling factors applied to the quotient of RREI and ETS body weights, as expressed in Eq. 9, are all summarized for each CPEC in Table B-6.

A value less than one for the EHQ $\mathrm{CPEC}_{\mathrm{CRREI-Low}}$ is considered to indicate a condition of de minimis ecological risk for an individual or population of RREI as a result of exposures to that CPEC. Where a value for the $\mathrm{EHQ}_{\mathrm{CPEC}-\mathrm{RREI}-\mathrm{Low}}$ is predicted to be greater than or equal to one, then the $\mathrm{EHQ}_{\mathrm{CPEC}-\text { RREI-High }}$ is also calculated. Where the $\mathrm{EHQ}_{\mathrm{CPEC}-\mathrm{RREI} \text {-Low }}$ is greater than or equal to one but the $\mathrm{EHQ}_{\mathrm{CPEC}-\mathrm{RREI} \text {-High }}$ is less than one, further consideration of the data is needed. Many times, this involves reducing conservatism in parameter estimates by reassessing the applicability of the modeling conditions and data sets so they better reflect more realistic circumstances. Occasionally, resolution of this issue requires performing additional experiments or collecting additional environmental data; such additional work is even more likely to resolve issues when both an $\mathrm{EHQ}_{\text {CPEC-RREI- }}$ Low and $\mathrm{EHQ}_{\mathrm{CPEC} \text {-RREI-High }}$ are predicted to be greater than or equal to one.

\section{ERA Results}

The results of this ERA indicate that the individual and total doses of each CPEC for each RREI (see Table B-7) are never greater than the respective $\mathrm{TRV}_{\text {Low }}$ that is computed to predict the EHQ for each CPEC and RREI. Consequently, the $\mathrm{EHQ}_{\text {Low }}$ that is calculated for each CPEC and each RREI is always less than one (see Table B-8).

Table B-7 contains the individual and total doses for each CPEC and RREI. For the Kit Fox and Burrowing Owl it is the food pathway that produces the dominant dose for each CPEC. For the ground squirrel, incidental-soil ingestion contributes the dominant dose for copper and PCDDs/PCDFs, and the food pathway dominates the dose for the remaining heavy metals. For the Blacktailed Deer, the dominant dose for all heavy metals comes from the food pathway, but incidental soil ingestion produces the dominant dose for PCDDs/PCDFs. In all cases, the magnitude of the dose from heavy metals is always several orders of magnitude greater than any dose from PCDDs/PCDFs. 
Also, in all cases the inhalation of resuspended soil particles is never contributing significantly to total dose.

Table B-7. Exposure-pathway dose and total dose $\left[\mathrm{mg} /\left(\mathbf{k g} \_\cdot d\right)\right]$ estimates for each contaminant of potential ecological concern (CPEC) for each representative receptor of ecological interest (RREI).

\begin{tabular}{|c|c|c|c|c|}
\hline \multirow[t]{2}{*}{ CPEC } & \multicolumn{4}{|c|}{ California Ground Squirrel } \\
\hline & $\mathbf{D}_{\text {air }}$ & $\mathbf{D}_{\text {soil }}$ & $D_{\text {food }}$ & $D_{\text {total }}$ \\
\hline Cadmium (Cd) & $4.4 \times 10^{-9}$ & $3.5 \times 10^{-4}$ & $1.9 \times 10^{-3}$ & $2.2 \times 10^{-3}$ \\
\hline Copper (Cu) & $1.5 \times 10^{-6}$ & $2.3 \times 10^{-1}$ & $1.2 \times 10^{-1}$ & $3.4 \times 10^{-1}$ \\
\hline Lead $(\mathrm{Pb})$ & $3.0 \times 10^{-9}$ & $5.2 \times 10^{-4}$ & $9.7 \times 10^{-4}$ & $1.5 \times 10^{-3}$ \\
\hline Zinc $(Z n)$ & $7.7 \times 10^{-7}$ & $6.1 \times 10^{-2}$ & $2.6 \times 10^{-1}$ & $3.2 \times 10^{-1}$ \\
\hline PCDD/PCDF & $1.8 \times 10^{-13}$ & $1.4 \times 10^{-8}$ & $2.0 \times 10^{-10}$ & $1.4 \times 10^{-8}$ \\
\hline \multirow{2}{*}{ CPEC } & \multicolumn{4}{|c|}{ Black-tailed Deer } \\
\hline & $\mathbf{D}_{\text {air }}$ & $D_{\text {soil }}$ & $D_{\text {food }}$ & $D_{\text {total }}$ \\
\hline Cadmium (Cd) & $7.6 \times 10^{-9}$ & $3.3 \times 10^{-5}$ & $6.8 \times 10^{-4}$ & $7.1 \times 10^{-4}$ \\
\hline Copper $(\mathrm{Cu})$ & $4.9 \times 10^{-10}$ & $2.1 \times 10^{-2}$ & $4.2 \times 10^{-2}$ & $6.3 \times 10^{-2}$ \\
\hline Lead $(\mathrm{Pb})$ & $1.1 \times 10^{-8}$ & $4.8 \times 10^{-5}$ & $3.5 \times 10^{-4}$ & $4.0 \times 10^{-4}$ \\
\hline Zinc (Zn) & $1.3 \times 10^{-6}$ & $5.7 \times 10^{-3}$ & $9.3 \times 10^{-2}$ & $9.8 \times 10^{-2}$ \\
\hline PCDD/PCDF & $3.1 \times 10^{-13}$ & $1.3 \times 10^{-9}$ & $7.0 \times 10^{-11}$ & $1.4 \times 10^{-9}$ \\
\hline \multirow[t]{2}{*}{ CPEC } & \multicolumn{4}{|c|}{ San Joaquin Kit Fox } \\
\hline & $\mathbf{D}_{\text {air }}$ & $D_{\text {soil }}$ & $D_{\text {food }}$ & $D_{\text {total }}$ \\
\hline Cadmium (Cd) & $9.5 \times 10^{-9}$ & $1.4 \times 10^{-4}$ & $4.4 \times 10^{-3}$ & $4.5 \times 10^{-3}$ \\
\hline Copper (Cu) & $1.4 \times 10^{-6}$ & $9.0 \times 10^{-2}$ & $3.4 \times 10^{-1}$ & $4.3 \times 10^{-1}$ \\
\hline Lead $(\mathrm{Pb})$ & $1.1 \times 10^{-6}$ & $2.0 \times 10^{-4}$ & $9.7 \times 10^{-3}$ & $9.9 \times 10^{-3}$ \\
\hline Zinc (Zn) & $1.6 \times 10^{-6}$ & $2.4 \times 10^{-2}$ & $2.7 \times 10^{0}$ & $2.7 \times 10^{0}$ \\
\hline PCDD/PCDF & $3.8 \times 10^{-13}$ & $5.6 \times 10^{-9}$ & $3.6 \times 10^{-8}$ & $4.2 \times 10^{-8}$ \\
\hline \multirow[t]{2}{*}{ CPEC } & \multicolumn{4}{|c|}{ Burrowing Owl } \\
\hline & $D_{\text {air }}$ & $D_{\text {soil }}$ & $D_{\text {food }}$ & $D_{\text {total }}$ \\
\hline Cadmium (Cd) & $1.9 \times 10^{-8}$ & $5.1 \times 10^{-4}$ & $4.4 \times 10^{-3}$ & $4.9 \times 10^{-3}$ \\
\hline Copper $(\mathrm{Cu})$ & $1.3 \times 10^{-6}$ & $3.3 \times 10^{-1}$ & $3.5 \times 10^{-1}$ & $6.7 \times 10^{-1}$ \\
\hline Lead $(\mathrm{Pb})$ & $2.4 \times 10^{-6}$ & $7.4 \times 10^{-4}$ & $9.8 \times 10^{-3}$ & $1.1 \times 10^{-2}$ \\
\hline Zinc (Zn) & $3.2 \times 10^{-6}$ & $8.8 \times 10^{-2}$ & $2.8 \times 10^{0}$ & $2.8 \times 10^{0}$ \\
\hline PCDD/PCDF & $7.5 \times 10^{-13}$ & $2.0 \times 10^{-8}$ & $3.7 \times 10^{-8}$ & $5.7 \times 10^{-8}$ \\
\hline
\end{tabular}


Using this technical approach for the ERA allows each CPEC to be screened quantitatively for each RREI with respect to its potential (by inference) for producing an adverse ecological effect. As the results in Table B-8 reveal, no $\mathrm{EHQ}_{\text {Low }}$ is greater than or equal to one, and in all cases the $\mathrm{EHQ}_{\mathrm{CPEC}-\mathrm{RREI}}$ is derived based on body weight scaling of the TRV $\mathrm{TPEC-ETS}_{\text {to }}$ one applicable directly to the respective wildlife RREI (TRV CPEC-RREI $_{\text {; }}$ see Eq. 9 and Table B-6). For these reasons,

Table B-8. Ecological hazard quotients (i.e., ratio of total dose to respective TRV) for each representative receptor of interest (RREI) and contaminant of potential ecological concern (CPEC) based on body-weight scaling of toxic reference value in an experimental test species (ETS) to that of the RREI using Eq. 9.

\begin{tabular}{|c|c|c|c|c|c|c|c|c|}
\hline \multirow{2}{*}{$\begin{array}{l}\text { Chemicals } \\
\text { of potential } \\
\text { ecological } \\
\text { concern } \\
\text { (CPEC) }\end{array}$} & \multicolumn{2}{|c|}{$\begin{array}{c}\text { California Ground } \\
\text { Squirrel }\end{array}$} & \multicolumn{2}{|c|}{$\begin{array}{l}\text { Black-tailed } \\
\text { Deer }\end{array}$} & \multicolumn{2}{|c|}{$\begin{array}{l}\text { San Joaquin } \\
\text { Kit Fox }\end{array}$} & \multicolumn{2}{|c|}{$\begin{array}{c}\text { Burrowing } \\
\text { Owl }\end{array}$} \\
\hline & $E H Q_{\text {Low }}$ & $E H Q_{\text {High }}$ & $E H Q_{\text {Low }}$ & $E H Q_{\text {High }}$ & $E H Q_{\text {Low }}$ & $E H Q_{\text {High }}$ & $E H Q_{\text {Low }}$ & $E H Q_{\text {High }}$ \\
\hline $\begin{array}{l}\text { Cadmium } \\
\text { (Cd) }\end{array}$ & 0.19 & 0.0044 & 0.84 & 0.019 & 0.82 & 0.019 & 0.092 & 0.00071 \\
\hline $\begin{array}{l}\text { Copper } \\
\text { (Cu) }\end{array}$ & 0.15 & 0.00065 & 0.037 & 0.00016 & 0.21 & 0.00088 & 0.46 & 0.020 \\
\hline Lead $(\mathrm{Pb})$ & 0.0015 & 0.0000074 & 0.00054 & 0.0000026 & 0.011 & 0.000053 & 0.75 & 0.0019 \\
\hline Zinc $(Z n)$ & 0.040 & 0.00080 & 0.016 & 0.00038 & 0.37 & 0.0086 & 0.25 & 0.025 \\
\hline $\begin{array}{l}\text { PCDDs/ } \\
\text { PCDFs }\end{array}$ & 0.0018 & $\begin{array}{l}\text { None } \\
\text { available }\end{array}$ & 0.0015 & $\begin{array}{l}\text { None } \\
\text { available }\end{array}$ & 0.0097 & $\begin{array}{l}\text { None } \\
\text { available }\end{array}$ & 0.00059 & $\begin{array}{l}\text { None } \\
\text { available }\end{array}$ \\
\hline
\end{tabular}

Note: The toxic reference values (TRVs) for PCDDs/PCDFs were obtained from an ecological risk assessment prepared for Toronto (Canada) Public Health by Jacques Whitford Limited (2004) and are considered representative of TRV $\mathrm{L}_{\text {Low }} s$. All other TRV values were obtained from DTSC $(2002 a, b)$. In calculating EHQs, a scaling factor based on body weight was applied to convert the TRV obtained from the literature for an experimental test species to a TRV that is considered more directly applicable to the representative receptor of ecological interest.

and because of additional conservatism incorporated into the derivation of doses (e.g., maximum annual soil concentrations; optimizing each RREI behavior to maximize exposures; and fixing absorption at 100\%), it is likely the results appearing in Table B-8 are overestimates. Therefore, even in cases where the $\mathrm{EHQ}_{\text {Low }}$ approaches 1 (e.g., 0.84 and 0.82 for $\mathrm{Cd}$ in deer and Kit Fox, respectively; 0.75 for $\mathrm{Pb}$ in Burrowing Owl), it is not likely these values would be greater, even with better input data [see for example, predicted uptake factor data for cadmium developed by Bench et al. (2001)]. 


\section{ERA Conclusions}

Quantification of the ecological risk posed by release of a particular contaminant to a specific habitat is complicated by additional uncertainties related to limited data concerning the physiological and behavioral characteristics of those wildlife species that are considered to be present. To overcome such difficulties, quantitative ecological risk assessment, as currently practiced, focuses on modeling potential total dose and developing an EHQ for an individual organism in one or more species (and most often only for adults due to data limitations) in the affected habitat, such that any impact to an individual of a particular species may translate to an impact to the population, and by inference, to a potential impact on the entire local ecosystem. Following this approach, this ERA examines the potential for impact from a CPEC for an individual RREI from more than one species, with each species considered to be at a different trophic level in the local ecosystem near the EWTF. Additional conservatism is added to these ERA calculations by maximizing the amount of material deposited (by considering a habitat location at Site 300 quite close to the OB/OD operations - the source of emissions); optimizing the RREI behavior to maximize exposures (i.e., living, foraging, and capturing prey exclusively in that immediate habitat); and fixing the absorption fraction of each CPEC from the lungs and intestinal tract of each RREI at $100 \%$. Adding these conservatisms acts to address uncertainty because they increase the likelihood that each calculated EHQ will be an overestimate.

Because none of the resulting values for $\mathrm{EHQ}_{\mathrm{Low}}$ in this ERA are greater than or equal to one, having also added conservatisms to the inputs, it is therefore expected that OB/OD operations at Site 300 are unlikely to produce or contribute significantly to any ecological impacts. Should these results have indicated otherwise, they would have triggered further investigation. Under such circumstances a detailed location-specific, wildlife-field survey would be undertaken, as has been done in the past for other locations at Site 300 where an EHQ has been determined to exceed 1 (see for example, Dibley et al., 2005).

\section{References}

Bench, G., T.M. Carlsen, P.G. Grant, J.S. Wollett, Jr., R.E. Martinelli, J.L. Lewis, and K.K. Divine (1998), “Olfactory Bulb Uptake and Determination of Biotransfer Factors in the California Ground Squirrel (Spermophilus beecheyi) Exposed to Manganese and Cadmium in Environmental Habitats," Environ. Sci. Technol. 35, 270-277.

Biermann, A., P. Althouse, N. Bertoldo, R. Blake, S. Brigdon, R. Brown, C. Campbell, E. Christofferson, L. Clark, K. Folks, G. Gallegos, A. Grayson, R. Harrach, J. Larson, D. MacQueen, S. Mathews, B. Nisbet, S. Peterson, M. Taffet, P. Tate, R. Vellinger, and R. Williams (2001), Environmental Report for 2000, Lawrence Livermore National Laboratory, Livermore, CA (UCRL-50027-00).

Bjorklund, J.R., J. F. Bowers, G. C. Dodd, and J. M. White (1998), Open Burn/Open Detonation Dispersion Model (OBODM), User's Guide, West Desert Test Center, Dugway Proving Ground, Dugway, UT (DPG Document No. DPG-TR-96-008a). 
Carlsen, T.M. (1996), “Ecological Risks to Fossorial Vertebrates from Volatile Organic Compounds in Soil," Risk Analysis 16(2), 211-219.

Denton, J.E. (2003), Memorandum to W.H. Hickox, Secretary for California Environmental Protection Agency: Adoption of the Revised Toxicity Equivalency Factors (TEF $F_{\text {Wно-g) }}$ ) for PCDDs, PCDFs, and Dioxin-Like PCBs, State of California Environmental Protection Agency, Director of the Office of Health Hazard Assessment, Sacramento, CA, August 29, 2003, see Attachment, (URL: http:/ / www.oehha.ca.gov/air/hot spots/pdf/adoptionwhotefs.pdf).

Department of Toxic Substances Control (DTSC) (2000), Use of Navy/U.S. Environmental Protection Agency (USEPA) Region 9 Biological Technical Assistance Group (BTAG) Toxicity Reference Values (TRVs) for Ecological Risk Assessment, State of California Environmental Protection Agency (Cal/EPA), Department of Toxic Substances Control (DTSC), Sacramento, CA, Human and Ecological Risk Division (HERD) Ecological Risk Assessment (ERA) Note Number 4 (EcoNote4), December 8, 2000 (URL:

http:/ / 165.235.111.242/AssessingRisk/eco.cfm\#EcoNOTE5).

Department of Toxic Substances Control (DTSC) (2002a), Revised U.S. Environmental Protection Agency (USEPA) Region 9 Biological Technical Assistance Group (BTAG) Mammalian Toxicity Reference Value (TRV) for Lead: Justification and Rationale, State of California Environmental Protection Agency (Cal/EPA), Department of Toxic Substances Control (DTSC), Sacramento, CA, Human and Ecological Risk Division (HERD) Ecological Risk Assessment (ERA) Note Number 5 (EcoNote5), November 21, 2002 (URL: http:/ / 165.235.111.242/AssessingRisk/eco.cfm\#EcoNOTE5).

Department of Toxic Substances Control (DTSC) (2002b), Currently Recommended U.S. Environmental Protection Agency Region 9 Biological Technical Assistance Group (BTAG) Mammalian and Avian Toxicity Reference Values (TRVs), State of California Environmental Protection Agency (Cal/EPA), Department of Toxic Substances Control (DTSC), Sacramento, CA, November 21, 2002 ; two data tables and accompanying references (URL: http:/ / 165.235.111.242/AssessingRisk/eco.cfm\#EcoNOTE5).

Department of Fish and Game (DFG) (2005a), California's Wildlife: Volume III. Mammals, State of California Department of Fish and Game, Wildlife Habitat Data Analysis Branch, Sacramento, CA (URL: http:// www.dfg.ca.gov/whdab/html/lifehistmammal.html)

Dibley, V., T. Carlsen, S. Chamberlain, W. Daily, Z. Demir, M. Denton, R. Goodrich, S. Gregory, V. Madrid, M. Taffett, J. Valett (2005), 2004 Annual Compliance Monitoring Report, Lawrence Livermore National Laboratory, Site 300, Environmental Protection Department, Lawrence Livermore National Laboratory, Livermore, CA, UCRL-AR-2006319-04; see §4.2. Ecological Risk and Hazard Management, pp. 41-44.

Efroymson, R.A., B.E. Sample, and G.W. Suter (2001), “Uptake of Inorganic Chemicals from Soil by Plant Leaves: Regressions of Field Data," Environ. Toxicol. Chem. 20, 2561-2571. 
Jacques Whitford Limited (2004), "Chapter 7. Ecological Risk Assessment" in Biosolids Pellet Review Study: Human Health and Ecological Risk Assessment, Prepared for Toronto Public Health by Jacques Whitford Engineering, Scientific and Management Consultants, Markham, Ontario, Canada, Project No. ONT36194, pp. 115-138, (URL: http:// www.toronto.ca/health/hphe/bio solids.htm).

Sample, B.E., M.S. Aplin, R.A. Efroymson, G.W. Suter, II, and C.J.E. Welsh (1997), Methods and Tools for Estimation of the Exposure of Terrestrial Wildlife to Contaminants, Oak Ridge National Laboratory, Oak Ridge, TN, ORNL/TM13391.

Sample, B.E., and C.A. Arenal (1999), "Allometric Models for Interspecies Extrapolation of Wildlife Toxicity Data," Bull. Env. Contamin. Toxicol. 62, 653-663.

State of California Environmental Protection Agency, Air Resources Board (ARB) (2003), HotSpots Analysis and Reporting Program User Guide, Developed by Dillingham Software Engineering, Inc., Air Resources Board, Stationary Source Division, Sacramento, CA.

State of California Department of Fish and Game (DFG) (2005b), California's Wildlife: Volume II. Birds, State of California Department of Fish and Game, Wildlife Habitat Data Analysis Branch, Sacramento, CA (URL: http://www.dfg.ca.gov/whdab/html/lifehistbirds.html)

Thomsen, L. (1971), "Behavior and Ecology of Burrowing Owls on the Oakland Municipal Airport," The Condor 73, 177-192.

Travis, C.C., and A.D. Arms (1988), "Bioconcentration of Organics in Beef, Milk, and Vegetation," Environ. Sci. Technol. 22, 271-274.

United States Department of Energy, National Nuclear Security Administration (USDOE/NNSA) (2004), Draft Site-wide Environmental Impact Statement for Continued Operation of Lawrence Livermore National Laboratory and Supplemental Stockpile Stewardship and Management Programmatic Environmental Impact Statement (LLNL SW/SPEIS), U.S. Department of Energy, Washington, DC, DOE/EIS-0348 and DOE/EIS-0236-S3.

United States Environmental Protection Agency (USEPA) (1993), Wildlife Exposure Factors Handbook, U.S. Environmental Protection Agency, Washington, DC, EPA/600/R-93/187.

Zarn, M. (1974), Report No. 11: Habitat Management Series for Unique or Endangered Species, U.S. Department of Interior, Bureau of Land Management, Denver, CO, Technical Note 250 . 